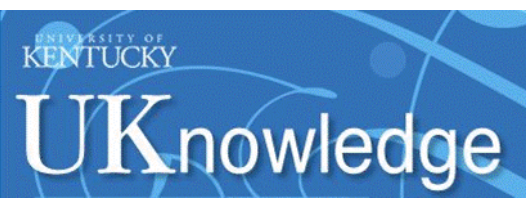

Kentucky Law Journal

\title{
Re-readings and Misreadings: Slaughter-House, Privileges or Immunities, and Section Five Enforcement Powers
}

James W. Fox Jr.

Stetson University

Follow this and additional works at: https://uknowledge.uky.edu/klj

Part of the Constitutional Law Commons, and the Fourteenth Amendment Commons

Right click to open a feedback form in a new tab to let us know how this document benefits you.

\section{Recommended Citation}

Fox, James W. Jr. (2002) "Re-readings and Misreadings: Slaughter-House, Privileges or Immunities, and Section Five Enforcement Powers," Kentucky Law Journal: Vol. 91: Iss. 1, Article 4.

Available at: https://uknowledge.uky.edu/klj/vol91/iss1/4 


\title{
Re-readings and Misreadings: Slaughter-House, Privileges or Immunities, and Section Five Enforcement Powers
}

\author{
BY JAMES W. FOX JR."
}

\section{INTRODUCTION}

The Supreme Court has inspired mountains of commentary with 1 recent decisions in two separate areas of Fourteenth Amendment jurisprudence. On the one hand, the Court has suggested in Saenz v. Roe ${ }^{1}$ that the Privileges or Immunities Clause of the Fourteenth Amendment may be re-opened as a source of constitutional rights. On the other, the Court has repeatedly and forcefully sought to restrain congressional powers to interpret and enforce the Fourteenth Amendment under the Enforcement Clause of Section Five. While each of these areas of Fourteenth Amendment analysis has seen its share of commentary, little has been said by either the Court or the commentators about the connections between these Clauses of the Fourteenth Amendment. This Article contends that the historical background of the framing and the early application of the Fourteenth Amendment reveal an intimate and arguably essential connection between the proper interpretation of the Privileges or Immunities Clause and congressional enforcement powers under Section Five of the United States Constitution.

- Assistant Professor of Law, Stetson University College of Law. J.D. 1990, University of Michigan Law School. Copyright (O 2002 James W. Fox Jr. All rights reserved. I owe special thanks to my colleagues: Michael Allen, Robert Batey, Robert Bickel, Mark Brown, and Peter Lake, who commented on early drafts of this Article, Richard Aynes, Michael Kent Curtis, Michael McConnell, William Rich, and Bryan Wildenthal, whose work inspired my efforts and who provided excellent advice on short notice, and my colleagues at Stetson who allowed me to refine ideas in our Faculty Workshop Series. I also thank my research assistant Kelley Cramer, the Stetson faculty support staff, and staff of the Stetson Law Library. Finally, my work on this project was supported by the Stetson University College of Law Research Grant Program.

' Saenz v. Roe, 526 U.S. 489 (1999). 
A common focal point for discussions about the Privileges or Immunities Clause is the Slaughter-House Cases. ${ }^{2}$ The long and widely held view of Slaughter-House is that Justice Miller's opinion for the Court eviscerated the Privilege or Immunities Clause and that the Clause has been a nullity ever since. Two scholars have recently attempted to explode this reading of Justice Miller's opinion. Kevin Newsom, through a close reading of Justice Miller's opinion and a detailed examination of Miller's jurisprudence, argues that Justice Miller in fact supported selective incorporation of the Bill of Rights through the Privileges or Immunities Clause. ${ }^{3}$ Professor Bryan $\mathrm{H}$. Wildenthal presents a similar reading of Miller's Slaughter-House opinion and argues that such a reading was the baseline of contemporaneous interpretations of the Clause in 1873 when the case was decided. ${ }^{4}$

This Article contends that these revisionist interpretations of SlaughterHouse, even if partially correct as an interpretation of the Court's opinion on the issue of incorporation, wrongly perpetuate Justice Miller's misreading of the Privileges or Immunities Clause. Revisionists focus on the wrong misreading: while it may be that scholars have gotten SlaughterHouse wrong, the more important problem is that Slaughter-House got the Privileges or Immunities Clause wrong.

The revisionists' misreading of the Privileges or Immunities Clause stems, in part, from their failure to grapple with the ambiguities of the historical evidence surrounding the Clause. For example, revisionists contend that the Clause does not encompass natural rights. ${ }^{5}$ Yet there is

${ }^{2}$ The Slaughter-House Cases, 83 U.S. (16 Wall.) 36 (1872).

${ }^{3}$ Kevin Christopher Newsom, Setting Incorporationism Straight: A Reinterpretation of the Slaughter-House Cases, 109 YALE L.J. 643, 649 (2000).

${ }^{4}$ Bryan H. Wildenthal, The Lost Compromise: Reassessing the Early Understanding in Court and Congress on Incorporation of the Bill of Rights in the Fourteenth Amendment, 61 OHIO ST.L.J. 1051 (2001) [hereinafter Wildenthal, The Lost Compromise]. See also Bryan H. Wildenthal, How I Learned to Stop Worrying and Love the Slaughter-House Cases: An Essay in ConstitutionalHistorical Revisionism, 23 T. JEFFERSON L. REV. 241 (2001) [hereinafter Wildenthal, How I Learned to Stop Worrying]. For an earlier, less developed exploration of the revisionist view, see Robert C. Palmer, The Parameters of Constitutional Reconstruction: Slaughter-House, Cruikshank, and the Fourteenth Amendment, 1984 U..ILL. L. REV. 739.

${ }^{3}$ Of the revisionists, Professor Wildenthal is the most willing to acknowledge that some of the framers of the Fourteenth Amendment believed it encompassed natural rights, but he still advocates a limited enumerated-rights interpretation. See infra notes 89-91 and accompanying text. 
significant evidence to the contrary that the revisionists do not adequately address. More importantly, based on a reading of the historical materials surrounding the drafting of the Fourteenth Amendment and its implementation by the Reconstruction Congresses, this Article contends that the Privileges or Immunities Clause and the enforcement powers of Section Five were thought to operate in unison, enabling Congress to determine some of the content of the privileges and immunities of national citizenship beyond a mechanical application of the Supreme Court's interpretation of the Bill of Rights. Ultimately, the revisionists fail to grasp that the historical record reveals a range of possible interpretations of the Clause and its enforcement, a range that modern interpreters need to confront in all its complexity and ambiguity.

Scholars investigating the Court's interpretation of Section Five, to the extent they explore its historical background, tend to focus on the contemporary connection of the Section to other portions of Section One- the Due Process and Equal Protection Clauses - and do not consider the possibility that the more appropriate, and perhaps intended, connection is with the Privileges or Immunities Clause. ${ }^{6}$ Moreover, the Supreme Court,

${ }^{6}$ See, e.g., Evan H. Caminker, "Appropriate" Means-Ends Constraints on Section 5 Powers, 53 STAN. L. REv. 1127, 1158-65 (2001) (discussing historical support for interpreting Section Five consistently with the Necessary and Proper Clause); Ruth Colker, The Section Five Quagmire, 47 UCLA L. REv. 653, 662-64 (2000); Ronald D. Rotunda, The Powers of Congress Under Section 5 of the Fourteenth Amendment After City of Boerne v. Flores, 32 IND. L. REV. 163, 169 (1998). Important recent exceptions include William J. Rich, Privileges or Immunities: The Missing Link in Establishing Congressional Power to Abrogate State Eleventh Amendment Immunity, 28 HASTINGS CONST. L.Q. 235 (2001) [hereinafter Rich, Privileges or Immunities: The Missing Link] and Rebecca E. Zietlow, Belonging, Protection and Equality: The Neglected Citizenship Clause and the Limits of Federalism, 62 U. PITT. L. REV. 281 (2000). Professor Rich focuses on the effect of the Enforcement Clause on the abrogation of Eleventh Amendment Immunities, which is central to some of the recent Supreme Court cases but is not an issue that I address here. Professor Zietlow focuses on the importance of the Citizenship Clause in supporting congressional actions, and emphasizes that the Citizenship Clause played a role in the Saenz decision. See also Akhil Reed Amar, Intratextualism, 112 HARV. L. REV. 747, 824 (1999) [hereinafter Amar, Intratextualism] (briefly suggesting the possibility that Congress was intended to have the power to define privileges of citizenship); Michael $\cdot \mathrm{W}$. McConnell, Comment, Institutions and Interpretation: A Critique of City of Boerne v. Flores, 111 HARV. L. REV. 153, 174-81 (1997) [hereinafter McConnell, Institutions and Interpretation] (criticizing the Boerne Court's historical analysis of Section Five and suggesting a congressional role in interpreting the Privileges 
in a series of recent decisions beginning in 1997 with City of Boerne $v$. Flores $^{7}$ and continuing through 2001 with Board of Trustees v. Garrett, ${ }^{8}$ has narrowly interpreted the scope of congressional powers to interpret and enforce the Fourteenth Amendment. In doing so, the Court initially relied on poor historical analysis in Boerne and has, for the most part, simply compounded its mistake by repeated cross-citations to Boerne. ${ }^{9}$ The historical investigation presented by this Article suggests first that the Enforcement Clause be interpreted more broadly than the five-Justice majority of the current Court has allowed. Second, and perhaps more significantly, if it is true that Congress was understood to play an important role in developing the contours of the Privileges or Immunities Clause, then actions by Congress that are based on its understanding of the Clause should be accorded more deference than the current Court seems willing to grant. Ultimately, this historical exploration suggests that by re-uniting the historical understandings of the Privileges or Immunities Clause with the

or Immunities Clause); William J. Rich, Taking "Privileges or Immunities" Seriously: A Call to Expand the Constitutional Canon, 87 MNN. L. REV. (forthcoming 2002) (draft on file with author) [hereinafter Rich, Taking "Privileges or Immunities" Seriously]; Brent E. Simmons, The Invincibility of Constitutional Error: The Rehnquist Court's States 'Rights Assault on Fourteenth Amendment Protections of Individual Rights, 11 SeTON HaLl CONST. L.J. 259, 352-63 (2001).

${ }^{7}$ City of Boerne v. Flores, 521 U.S. 507 (1997).

${ }^{8}$ Board of Trustees v. Garrett, 531 U.S. 356 (2001). The other cases comprising the Section Five parade are Florida Prepaid Postsecondary Educ. Expense Bd. v. Coll. Sav. Bank, 527 U.S. 627 (1999); Kimel v. Fla. Bd. of Regents, 528 U.S. 62 (2000); United States v. Morrison, 529 U.S. 598 (2000). For an excellent analysis of the Court's aggressive and hostile approach to congressional actions in these recent cases, see Ruth Colker \& James J. Brudney, Dissing Congress, $100 \mathrm{MICH}$. L. REV. 80 (2001). For two interesting critiques of Morrison, which also present productive ways to re-think Section Five as applied to women and sex discrimination, see Zietlow, supra note 6 (advocating use of the Citizenship Clause of the Fourteenth Amendment as a basis for congressional action such as the Violence Against Women Act, ruled unconstitutional in Morrison); and Reva B. Seigel, She the People: The Nineteenth Amendment, Sex Equality, Federalism, and the Family, 115 HARV. L. REV. 947 (2002) (arguing that the Nineteenth Amendment supports an understanding of Fourteenth Amendment protections specifically adapted to sex discrimination and supportive of congressional actions such as the Violence Against Women Act).

${ }^{9}$ See, e.g., Florida Prepaid, 527 U.S. at 638. For an excellent critique of the Boerne Court's historical analysis, see McConnell, Institutions and Interpretation, supra note 6, at 153. 
Enforcement Clause modern interpreters might find a plausible but overlooked constitutional basis for congressional actions aimed at protecting the rights of groups such as women, individuals with disabilities, and religious minorities.

The Article proceeds as follows: Part I presents the arguments of the revisionists and their re-reading of the Slaughter-House Cases. Critiquing the revisionists on their own terms, I find that they provide an overly charitable reading of Justice Miller's opinion on the incorporation question. ${ }^{10}$ Part II addresses what I regard as the more important issue: The revisionists' adoption of Justice Miller's misreading of the Privileges or Immunities Clause to exclude natural rights interpretations and to restrict the role of Congress in developing the interpretive content of the Clause. ${ }^{11}$ This issue is addressed by concentrating on historical evidence from congressional debates about both the Fourteenth Amendment and contemporaneous legislation such as the Civil Rights Act of $1866^{12}$ and the Freedmen's Bureau Act. ${ }^{13}$

Part III pursues this analysis with a close reading of some of the congressional actions throughout Reconstruction, and demonstrates first that the Thirty-ninth Congress (which drafted the Fourteenth Amendment) adopted an aggressive understanding of its parallel enforcement powers under the Thirteenth Amendment through enactment of the Civil Rights Act $^{14}$ and Anti-Peonage Act, ${ }^{15}$ and second that Congress fully comprehended that its enforcement power included the power to interpret and define the content of the Reconstruction Amendments. ${ }^{16}$ Part III then goes on to explore congressional debates over the Enforcement (Anti-Klan) Act of $187.1^{17}$ and the Civil Rights Act of $1875^{18}$ in an effort to understand the congressional interpretations of the content of the Privileges or Immunities Clause and the Clause's relationship to Section Five's enforcement powers. ${ }^{19}$ This Article argues that Congress took a fairly broad view of the Clause and its own powers prior to the Supreme Court's decision in

\footnotetext{
${ }^{10}$ See infra notes 22-68 and accompanying text.

${ }^{11}$ See infra notes 69-179 and accompanying text.

${ }^{12}$ Civil Rights Act, 14 Stat. 27 (1866).

${ }^{13}$ Freedmen's Bureau Act, 14 Stat. 173 (1866).

${ }^{14}$ Civil Rights Act, 14 Stat. 27 (1866).

${ }^{15}$ Anti-Peonage Act, 14 Stat. 546 (1867).

${ }^{16}$ See infra notes 180-304 and accompanying text.

${ }^{17}$ Enforcement Act, 17 Stat. 13 (1871).

${ }^{18}$ Civil Rights Act, 18 Stat. 335 (1875).

${ }^{19}$ See infra notes 305-35 and accompanying text.
} 
Slaughter-House, including the power to define national privileges and immunities with reference to the Bill of Rights, the Privileges or Immunities Clause, and rights considered "fundamental" based both on common law and on developing conceptions of democratic citizenship. Part III also discusses how the Slaughter-House decision partly re-directed congressional discourse away from a more expansive, fundamental rights interpretation of the Clause, and toward a more constrained equality-of-rights interpretation. Finally, Part IV discusses the final blow to congressional development of the Privileges or Immunities Clause: The Civil Rights Cases. ${ }^{20}$ With the Court's restrictive interpretation of the state action language of the Fourteenth Amendment, authored by Justice Bradley, one of the Slaughter-House dissenters, there remained little chance for congressional exploration. Such restrictions need not continue, however, and Part IV also suggests some avenues through which Congress could develop the Privileges or Immunities Clause. ${ }^{21}$

\section{WHAT IS SLAUGHTER-HOUSE REVISIONISM?}

Scholars and courts have long viewed the Slaughter-House Cases $^{22}$ as having eviscerated the Privileges or Immunities Clause of the Fourteenth Amendment. ${ }^{23}$ This "standard" twentieth century interpretation of Slaughter-House posits that the Court interpreted the Clause into redundancy. The Court achieved this, it is argued, in two stages: First, the Court held that by distinguishing between national and state citizenship in the first sentence of Section One, and then specifically protecting only the "privileges or immunities of citizens of the United States," the Amendment meant to distinguish the privileges and immunities encompassed by each type of citizenship. Second, the Court determined that the privileges and

${ }^{20}$ The Civil Rights Cases, 109 U.S. 3 (1883).

${ }^{21}$ See infra notes 305-35 and accompanying text.

${ }^{22}$ The Slaughter-House Cases, 83 U.S. (16 Wall.) 36 (1872).

${ }^{23}$ The Amendment reads:

All persons born or naturalized in the United States, and subject to the jurisdiction thereof, are citizens of the United States and of the State wherein they reside. No State shall make or enforce any law which shall abridge the privileges or immunities of citizens of the United States; nor shall any State deprive any person of life, liberty, or property, without due process of law; nor deny to any person within its jurisdiction the equal protection of the laws.

U.S. ConsT. amend. XIV, $\S 1$. 
immunities of national citizenship amounted only to those privileges otherwise secured by the Constitution. ${ }^{24}$ Thus, according to Professor Tribe's 1988 treatise, "[t]he Slaughter-House definition of national rights renders the [F]ourteenth amendment's privileges or immunities clause technically superfluous; rights preexisting in 'the Federal government, its National character, its Constitution, or its laws,' were by definition already shielded from state infringement by [the Constitution and constitutional principles]."25

The revisionists challenge this reading. They contend that Justice Miller's opinion for the Court in Slaughter-House, while rejecting broad interpretations of the Privileges or Immunities Clause, such as those put forth by the dissents, may actually support incorporation of the Bill of Rights. The revisionists set forth several important considerations in their effort to resurrect Miller's opinion. As discussed below, I find their reading of the Bill of Rights incorporation into Miller's opinion to be intriguing but strained. But that is not the focus of my criticism. I am concerned that these incorporationist readings of the case evidence a deeper problem: the revisionists' acceptance of Miller's de-federalization of the fundamental rights theory of the Privileges or Immunities Clause. Before addressing these issues, however, it is helpful to summarize briefly the SlaughterHouse Cases.

${ }^{24}$ E.g., LAWRENCE TRIBE, AMERICAN CONSTITUTIONAL LAW $\$ \S 7-2,7-3$ (2d ed. 1988). See also Saenz v. Roe, 526 U.S. 489, 521 (1999) (Thomas, J., dissenting) (Slaughter-House Court effectively read the Clause out of the Constitution); AKHIL REED AMAR, THE BILLOF RIGHTS: CREATION AND RECONSTRUCTION 212-13 (1998) [hereinafter AMAR, THE BILL OF RIGHTS]; CHARLES L. BLACK, JR., A NEW BIRTH OF FREEDOM: HUMAN RIGHTS, NAMED AND UNNAMED 39, 55 (1997); MICHAEL Kent CuRTIS, No State Shall ABridge 175 (1986) [hereinafter CuRTIS, No StATE Shall ABridge]; Richard L. Aynes, Constricting the Law of Freedom: Justice Miller, the Fourteenth Amendment, and the Slaughter-House Cases, 70 CHI.-KENT L. REV. 627, 653-55 (1994) [hereinafter Aynes, Constricting the Law of Freedom]; Erwin Chemerinsky, The Supreme Court and the Fourteenth Amendment: The Unfulfilled Promise, 25 LOY. L.A. L. REV. 1143, 1144 (1992); Jeffrey Rosen, Translating the Privileges or Immunities Clause, 66 GEO. WASH. L. REV. 1241, 1241 (1998). I have also previously adopted this view. See James W. Fox Jr., Citizenship, Poverty, and Federalism: 1787-1882, 60 U. PITT. L. REV.421, 545-51 (1999). See also sources cited in Newsom, supra note 3, at $648 \mathrm{n} .15$; and Wildenthal, The Lost Compromise, supra note 4, at 1063 n.41. Professors Tribe and Curtis have been influenced by the revisionist articles discussed herein and now accept the possibility of a different reading.

${ }^{25}$ TRIBE, supra note 24, $\$ 7-4$ (quoting Slaughter-House, 83 U.S. (16 Wall.) at 96). 
A. Slaughter-House

The Slaughter-House.Cases arose in New Orleans as an anti-monopoly dispute. Louisiana, like many states and cities of the period, enacted a law banning slaughter-houses within and around New Orleans, except for those operated by a state-sanctioned company in a designated area, in which slaughter-house butchers could ply their trade for a fee. ${ }^{26}$ Several butchers challenged the Act as an unconstitutional restriction of their rights under common law and the Thirteenth and Fourteenth Amendments. ${ }^{27}$ On behalf of the butchers, John Campbell argued that the Act created an illegal monopoly that prevented the butchers from using their own land and wrongly restricted their freedom to conduct a legal trade. He loosely associated this right to labor with the Thirteenth and Fourteenth Amendments. ${ }^{28}$.

This mixing of civil rights, federalism, and monopoly issues created a host of ironies throughout the Slaughter-House decision. Justice Bradley, along with Judge (and future Justice) Woods, found in favor of the butchers when one portion of the case came before the United States Circuit Court; Bradley then found himself being overturned by the Supreme Court decision,

${ }^{26}$ See ROBERT KACZOROWSKI, THE POLITICS OF JUDICIAL INTERPRETATION: THE FEDERAL COURTS, DEPARTMENT OF JUSTICE AND CIVIL RIGHTS, 1866-1876, 144 (1985) [hereinafter KACZOROWSKI, POLITICS OF JUDICIAL INTERPRETATION] (discussing growing use of slaughter-house regulations for public health and safety). Kaczorowski notes that the Louisiana regulations were heavily influenced by corrupt politics and were more severe in their treatment of the butchers than the regulations in other states. For an excellent historical analysis of the background of Slaughter-House and Justice Miller's motivations-often at odds with Kaczorowski's views-see Michael A. Ross, Justice Miller's Reconstruction: The Slaughter-House Cases, Health Codes, and Civil Rights in New Orleans, 18611873, 64 J.S. LEGAL. Hist. 649 (1998). See also Aynes, Constricting the Law of Freedom, supra note 24, at 632-34. For a detailed history of the cases, see generally Mitchell Franklin, The Foundations and Meaning of The Slaughterhouse Cases, 18 TUL. L. REV. 1 (1943).

${ }^{27}$ See generally Slaughter-House, 83 U.S. (16 Wall.) at 45-57; see also Brief for Plaintiffs, Slaughter-House (Nos. 475-480), reprinted in 6 LANDMARK BRIEFS AND ARGUMENTS OF THE SUPREME COURT OF THE UNITED STATES: CONSTITUTIONAL LAW 535 (Philip B. Kurland \& Gerhard Casper eds., 1975).

${ }^{28}$ See Slaughter-House, 83 U.S. (16 Wall.) at 54-56; LANDMARK BRIEFS, supra note 27, at 570-72. The bulk of Campbell's argument recounted the impermissibility of monopoly and the right to labor under his reading of the Anglo-American common law; he did far less expository work on the Reconstruction Amendments and the Privileges or Immunities Clause. 
to which he dissented. ${ }^{29}$ John Campbell, a former United States Supreme Court Justice and states-rightist who resigned from the Court to support his home state of Alabama in the Civil War, eloquently argued, on behalf of the butchers, the position favoring national citizenship and its privileges, supporting federal judicial power, and rejecting state legislative authority. Republicans - the party of nationalism-represented the state in its states' rights argument. One of Louisiana's attorneys, Senator Carpenter, had just two weeks before he argued in favor of a broad view of the Fourteenth Amendment to protect Myra Bradwell's right to practice law, and had also recently supported civil rights legislation in the Senate. ${ }^{30}$ The alignment of Carpenter and Campbell reflected how the infusion of anti-monopolism and Republican politics produced a complicated mixture of issues and positions. ${ }^{31}$

The Court, per Justice Miller, held for the state. Miller asserted that the "one pervading purpose" of the Reconstruction Amendments was "the freedom of the slave race, the security and firm establishment of that freedom, and the protection of the newly-made freeman and citizen from the oppressions of those who had formerly exercised dominion over him."32 While Miller noted that the amendments were not necessarily limited in application to former slaves, he still urged that interpretation of the amendments must consider the emancipation purposes behind their adoption. ${ }^{33}$ Against this

${ }^{29}$ KACZOROWSKI, POLITICS OF JUDICIAL INTERPRETATION, supra note 26, at 145. The lower court case is Live-Stock Dealers ' and Butchers' Ass ' $n$ v. Crescent City Live-Stock Landing and Slaughter-House Co., 15 F. Cas. 649 (C.C. La. 1870).

${ }^{30}$ See infra notes 261-64 and accompanying text.

${ }^{31}$ KACZOROWSKI, POLITICS OF JUDICIAL INTERPRETATION, supra note 26, at 146-48.

${ }^{32}$ Slaughter-House, 83 U.S. (16 Wall.) at 71.

${ }^{33} \mathrm{Id}$. at 72. Newsom makes much of Miller's caveat to claim that Miller did not mean to limit the scope of the Amendments to African-Americans: "[Miller] went out of his way to make clear" that the amendments were not limited to blacks. Newsom, supra note 3, at 683-85. Newsom's point is to reject the traditional reading - that Miller's "pervading purpose" argument shows that Miller did not intend to incorporate the Bill of Rights in the Fourteenth Amendment. Unfortunately, Newsom's reading clings to Miller's caveat while downplaying his extensive discussion of emancipation. Notably, immediately after his caveat, Miller emphasized the necessity of interpreting the amendments in light of their purpose in emancipating black slaves. SlaughterHouse, 83 U.S. (16 Wall.) at 72. So while Miller may have "gone out of his way," he quickly returned to the interpretive path which saw emancipation as the guiding principle for the amendments. The dominant effect of this portion of the opinion is to overly particularize the Fourteenth Amendment, which ultimately supports a restrictive, non-incorporationist reading. 
background, Miller then moved to the thrust of the opinion, the interpretation of the Privileges or Immunities Clause.

As mentioned above, it is Miller's reading of the Privileges or Immunities Clause that occasioned the debate taken up by the revisionists. Scholars seem to agree, however, that Miller intended to distinguish federal and state citizenship and the privileges and immunities attaching to each. Both the traditional reading of the opinion and the revisionists' reading also understand Miller to have limited fundamental rights to state citizenship and therefore placed those rights outside the scope of the federal government's powers. Miller is clear about this. He, like many others on the Court and in Congress, recognized the existence of fundamental rights and privileges that exist at the state level, such as the right to property, happiness, and safety. ${ }^{34}$ Unlike others on the Court and many in Congress, he then expressly held that the Fourteenth Amendment did not bring such rights within the purview of the federal government, but left them to the states to regulate and protect. ${ }^{35}$ In this way, the Court, per Miller, prevented the butchers from claiming federal constitutional protection for a right to labor and left Louisiana free to regulate slaughter-house operations through creation of a state-sanctioned monopoly.

\section{B. Slaughter-House and Incorporation of the Bill of Rights}

The revisionists do not stake their claim on this removal of fundamental rights from the scope of the Privileges or Immunities Clause. Instead, they concentrate on the argument that Miller's limitation did not include the Bill of Rights. First, they point out that the incorporation of the Bill of Rights was not even an issue in the case and that there is simply no holding on the matter by the Slaughter-House Court. Surely they are right to emphasize this point. Many of us have a tendency to over-read language in a case, to perpetuate prior over-readings, and to forget the points at issue. The revisionists clear out the malformed growth of such readings.

With their next step, revisionists move to shakier ground. They argue that, contrary to conventional wisdom, the Slaughter-House opinion can best be read to include the Bill of Rights in the listing of federal privileges. Actually, there are at least two approaches to this point. ${ }^{36}$ The first, and

${ }^{34}$ Slaughter-House, 83 U.S. (16 Wall.) at 76.

${ }^{35} I d$. at 77-78. The Court also held that the Equal Protection Clause was inapplicable to the case. Id. at 80-81.

${ }^{36}$ For both positions, see Newsom, supra note 3, at 683 ("[T] here is nothing in Slaughter-House that precludes a reading of the Privileges or Immunities Clause as incorporating the Bill of Rights. In fact, viewed in proper context, Miller's 
more cautious, approach is to point out that Miller, in listing the federal privileges and immunities, included some first amendment privileges: the "rights to peaceably assemble and petition for redress of grievances." 37 Based on this evidence, revisionists argue that Miller could not have intended to reject incorporation, especially since application of the Bill of Rights was not an issue necessary to the case.

The second, and more difficult, step is the revisionists' claim that Miller's opinion not only permits incorporation, but affirmatively contemplates incorporation. ${ }^{38}$ As Newsom observes, Miller expressly provided only a suggestive list of federal rights. ${ }^{39}$. Revisionists thus argue that the first amendment rights Miller cites suggest that other rights in the Bill of Rights are also federal privileges. This is not what Miller says. It is not at all clear from his list what the privileges of federal citizenship are beyond those listed in Slaughter-House. Miller's first asserted right is the right to travel to the seat of government and to seaports, a right he himself wrote into law prior to ratification of the Fourteenth Amendment in Crandall v. Nevada. ${ }^{40}$ This right is not textually based and Miller may have felt somewhat insecure about his prior invocation of the right; he may have seen Slaughter-House as an opportunity to rest the Crandall right on the firmer basis of the new amendment. Miller also cited, inter alia, rights to protection on the high seas, to use the navigable waters, to become a citizen of any state, and to be free of racial discrimination in voting as protected by the Fifteenth Amendment. It is hard to see what these rights "suggest" beyond a limited right to travel and the express language of the Constitution already applicable to the states. ${ }^{41}$ Thus the bulk of the "suggesting" done by the list, according to revisionists, is to bring in all of the Bill of Rights on the thin reed of the reference to assembly and petition and, perhaps, to the privilege of the writ of habeas corpus.

Others have read Miller's listing of petition, assembly, and habeas corpus to be limited to interactions with the national government. ${ }^{42}$

majority opinion ... seems quite possibly to contemplate incorporation.").

${ }^{37}$ Slaughter-House, 83 U.S. (16 Wall.) at 79.

${ }^{38}$ See Wildenthal, The Lost Compromise, supra note 4, at 1063 ("[Miller's opinion] was at worst ambiguous, and at best powerfully supportive of total incorporation.").

${ }^{39}$ See Slaughter-House, 83 U.S. (16 Wall.) at 79; Newsom, supra note 3, at 683.

${ }^{40}$ Crandall v. Nevada, 73 U.S. (16 Wall.) 35, 44 (1867).

${ }^{41}$ Wildenthal readily admits the weakness of this portion of Miller's list. See Wildenthal, The Lost Compromise, supra note 4, at 1098-99.

${ }^{42}$ See, e.g., KACZOROWSKI, POLITICS OF JUDICIAL INTERPRETATION, supra note 26 , at 152; Aynes, Constricting the Law of Freedom, supra note 24, at 652-55. 
Professor Wildenthal counters that this reading renders the list redundant because such rights were protected by Crandall and Miller had already listed Crandall's rights. ${ }^{43}$ This pushes the opinion too far in the other direction. While Miller's quote from Crandall does list a right "to come to the seat of government to assert any claim he may have upon that government," it does not so clearly encompass all assembly and petition of the national government. Crandall, after all, involved the right to travel across state lines without taxation, and Miller, writing for the Court, grounded this right on the right to travel to the seat of government "to assert any claim" on the government and to transact government business. ${ }^{44}$ Neither the facts of the case nor Miller's justification for the right to travel clearly involved a right to assemble and petition for national purposes within a state. ${ }^{45}$ It is quite plausible that, rather than incorporating the entire Bill of Rights, Miller meant for his reference to petition and assembly in Slaughter-House to expand or clarify the Crandall rights by emphasizing the right to petition and assemble for national purposes without travelling across state lines. Similarly, his invocation of habeas corpus could have been intended to require the right as against federal officers within one's own state.

Moreover, most of the specific rights Miller lists that surround petition, assembly, and habeas are rights that depend on a person's "character as a citizen of the Unites States" and the structure of the government. ${ }^{46}$ They are rights based on the citizen's interaction with the federal government. The reference to petition, assembly, and habeas are surrounded immediately by the right to protection on the high seas and the right to use the nation's navigable waters. ${ }^{47}$ It is only at the end of this listing of specific rights that Miller posits very generally other possible national rights- " $[\mathrm{t}] \mathrm{c}$ these may

\footnotetext{
${ }^{43}$ Wildenthal, The Lost Compromise, supra note 4, at 1100.

${ }^{44}$ Crandall, 73 U.S. (16 Wall.) at 44.

${ }^{45}$ Miller wrote that a United States citizen:

$[\mathrm{H}]$ as the right to come to the seat of government to assert any claim he may have upon that government, or to transact any business he may have with it. To seek its protection, to share its offices, to engage in administering its functions. He has a right to free access to its sea-ports, through which all the operations of foreign trade and commerce are conducted, to the subtreasuries, the land offices, the revenue offices, and the courts of justice in the several States, and this right is in its nature independent of the will of any State over whose soil he must pass in the exercise of it.
}

Id. At most, one could conclude from this language that a citizen has a right to go to the offices of government and to seaports. Perhaps the former might include a right to petition, but the right to assemble seems absent from this listing.

${ }^{46} \mathrm{Id}$.

${ }^{47}$ The Slaughter-House Cases, 83 U.S. (16 Wall.) 36, 79 (1872). 
be added the rights secured by the [T]hirteenth and [F]ifteenth articles of amendment, and by the other clause of the [F]ourteenth . ..."48 and he does not articulate whether the rights of the Reconstruction Amendments, whatever they are for him, protect citizens when exercising the rights outside the context of relations to the national government. The placement of petition, assembly, and habeas within a list of very specific rights of citizens relating to their national government just as easily suggests that these rights from the Bill of Rights only protect the citizen in her relation to national government as it does that the Bill of Rights applies to relations with the states. ${ }^{49}$

The revisionists also confront the problem that Miller's effort to bury and obscure the reference to even a limited set of the Bill of Rights appears willful when contrasted with Bradley's dissent. ${ }^{50}$ Justice Bradley specifically listed a wider range of rights from the Bill of Rights in his dissent and quite clearly asserted that these national rights were protected against state interference by the Privileges or Immunities Clause. ${ }^{51}$ Bradley's language needs no feats of interpretive archeology to locate the hidden incorporationism. If Miller had meant to agree with Bradley on this portion of the analysis, he could have done so clearly. Instead he submerged in a list of relatively insignificant privileges the rights to petition, to assemble, and the right to habeas corpus. Newsom responds that Miller's shorter listing is simply an acknowledgement that he did agree with Bradley and that the disagreement between them was on the inclusion of fundamental rights beyond the Bill of Rights. ${ }^{52}$ This is a remarkably charitable reading of the text. It seems far more sensible to read Miller the way his text asks to be read-as an oblique reference which contrasts with Bradley's clear and grand incorporationist statement precisely in order to inhibit such a reading. If Miller is to be credited with any intent here at all (it is possible Miller simply was not being careful in this listing), it should be the intent to do what he in fact did: use ambiguous language and structure because he knew the passage could be interpreted in either direction by future courts. ${ }^{53}$

${ }^{48}$ Id. at 80.

${ }^{49}$ See Aynes, Constricting the Law of Freedom, supra note 24, at 653-55 (rights cited by Miller are structured and consistent with (randall).

${ }^{50}$ See id. at 639-42 (Bradley, J., dissenting).

${ }^{51}$ Slaughter-House, 83 U.S. (16 Wall.) at 118-19.

52 Newsom, supra note 3, at 679-81.

${ }^{53} \mathrm{On}$ the issue of incorporation; Miller's opinion may in fact be a "classically transitional judicial opinion, filled with ambiguities sufficient to make any future legal development possible." MORTON HORWITZ, THE TRANSFORMATION OF AMERICAN LAW, 1780-1860, 39 (1977) (commenting on Tyler v. Wilkenson, 24 F. Cas. 472 (C.C.D.R.I. 1827)). 
This seems especially plausible in light of the revisionists' observation that the incorporation issue was dicta for the issues raised in the case; whereas ambiguity may be unacceptable in a holding, it is often essential in dicta if the Justices remain uncertain about how they plan to develop the legal issues in future cases.

Ultimately, the revisionist reading of Miller's "incorporationist" passage is no less strained than the relations-to-national-government reading to which they respond. The revisionist reading relies too heavily on implications from a thin reference to petition, assembly, and habeas to do all the work of incorporation that the revisionists ask of it. Miller's scant references contrast too sharply with Justice Bradley's clearer incorporationist language. It is in fact quite odd that revisionists such as Newsom, who credit Justice Miller with clarity and caution in his writings generally, ${ }^{54}$ would seek an interpretation of his opinion that asks readers to view Miller as not really being in control of his own obfuscations. ${ }^{55}$

Revisionists face a similar problem with Miller's misquoting of Article IV's Privileges and Immunities Clause. Miller, in arguing that natural or fundamental rights had long been understood as rights of state citizens and should continue to be so interpreted, misquoted Article IV as protecting rights of "citizens of the United States" rather than "citizens in the several states." ${ }^{.56}$ Dean Aynes and Professor Tribe have argued persuasively that this misquote may have been designed to avoid an interpretation that those natural rights were rights of United States citizens who were in the states, an interpretation arguably adopted by Representative Bingham and others. ${ }^{57}$ While Newsom acknowledges their point ${ }^{58}$ he does not adequately address it or explain why, in the face of such misquoting, Miller's opinion should continue to be read generously. ${ }^{59}$

${ }^{54}$ Newsom, supra note 3.

${ }^{55}$ For another view supporting the revisionist reading (written before the Newsom and Wildenthal pieces), see Earl M. Maltz, The Concept of Incorporation, 33 U. RiCH. L. REV. 525, 528-29 (1999) [hereinafter Maltz, The Concept of Incorporation].

${ }^{56}$ Miller made the same mistake in quoting the leading case on Article IV's Clause, Corfield v. Coryell, 6 F. Cas. 546, 550 (C.C.E.D. Pa. 1823).

${ }^{57}$ See TRIBE, supra note 24, § 15-2; Aynes, Constricting the Law of Freedom, supra note 24, at 636, 646-48. See also Slaughter-House, 83 U.S. (16 Wall.) at 117-18 (Bradley, J. dissenting).

${ }^{58}$ Newsom, supra note 3, at $653-55$.

${ }^{59}$ Newsom refers to Miller's similar partial quote of Corfield, which omitted "the enjoyment of life and liberty" from Corfield's list of privileges, as "careful pruning." This a very charitable reading of what otherwise appears to be a purposefully misleading and disingenuous technique of Miller's to rewrite prior 
Despite what I find to be their overly charitable reading of Miller's opinion, the revisionists provide some important evidence and arguments. In particular Professor Wildenthal offers an excellent examination of congressional views on incorporation after Slaughter-House, arguing convincingly that incorporation of the Bill of Rights was the conservative baseline of meaning understood for the Privileges or Immunities Clause within Congress. ${ }^{60}$ Kevin Newsom also advances our historical understanding by presenting a detailed examination of Justice Miller's judicial philosophy, which may well have supported incorporation ${ }^{61}$ My critique of their incorporationist readings notwithstanding, Iagree that these articles present good arguments on that point.

Yet, even if we accept the revision of Slaughter-House, fundamental problems remain. First, it is not clear what the reinterpretation achieves. The Bill of Rights is largely incorporated already ${ }^{62}$ The main achievement of the re-reading of Slaughter-House is the possibility of using it as precedent for shifting incorporation from the Due Process Clause to the Privileges or Immunities Clause. The revisionists expend an enormous amount of energy, and adopt an exceptionally generous reading of Miller's opinion, to achieve a simple shift in the constitutional source for an already accepted doctrine. ${ }^{63}$

Newsom responds to this with three important points. First, Newsom quotes John Hart Ely's trenchant observation: "[T]here is simply no avoiding the fact that the word that follows 'due' is 'process.' ... [W] apparently need periodic reminding that 'substantive due process' is a contradiction in terms - -sort of like 'green pastel redness." "

cases. Given Miller's more conservative personal position on Reconstruction, see Aynes, Constricting the Law of Freedom, supra note 24, at $659 \mathrm{nn} .222-24$, it seems odd to refuse to see his Slaughter-House rhetorical "pruning" as intentional implementation of a conservative re-reading.

${ }^{60}$ See generally Wildenthal, The Lost Compromise, supra note 4.

${ }^{61}$ See generally Newsom, supra note 3.

${ }^{62}$ Bryan H. Wildenthal, The Road to Twining: Reassessing the Disincorporation of the Bill of Rights, 61 OHIO. ST. L.J. 1457, 1525 (2000) [hereinafter Wildenthal, The Road to Twining] (only three of the twenty-four rights in the Bill of Rights remain unincorporated).

${ }^{63}$ One could argue that, quite apart from any shift in constitutional doctrine, rereading Slaughter-House is an important historical exercise in its own right. I agree. But this leads directly to my criticism below that the revisionists are misreading the historical background of the very amendment that Slaughter-House was interpreting.

${ }^{64}$ Newsom, supra note 3, at 737 (quoting JOHN HART ELY, DEMOCRACY AND DISTRUST: A THEORY OF JUDICIAL REVIEW 18 (1980)). 
of accepting an oxymoronic reading of the Due Process Clause in order to achieve incorporation deeply bothers Newsom, as it has many others, ${ }^{65}$ and may on its own be reason enough to move us back to the Privileges or Immunities Clause. Second, Newsom argues that the framers of the Amendment did not believe in substantive due process and we should not perpetuate this inconsistency with the framers' intent. ${ }^{66}$ Third, Newsom adopts Professors Aynes' and Richards' argument that a blatantly impermissible textual reading renders the resulting Supreme Court doctrine subject to public disrespect. ${ }^{67}$

Were a mere re-arrangement of the source for current doctrine the only consequence of the proposed re-readings of Slaughter-House, it would seem worthwhile considering the gain of linguistic sensibility, a stronger rhetorical stance for the Court, and greater acceptance of incorporation by Americans generally. But there is more lurking in the reinterpretations than meets the reader's eye. On one level, there may be problems with a shift in the overall doctrine once its foundation is moved: will the incorporation of the Bill of Rights through the Privileges or Immunities Clause result in any significant changes to those incorporated rights? Because of the Clause's focus on citizens rather than persons, non-citizens might not retain Bill of Rights' protections. The most obvious consequence of this would be the diminishment of constitutional protections for aliens. But also significant would be the effect on corporations, including news corporations which might lose First Amendment protections if the Supreme Court applies to the Fourteenth Amendment its Article IV holding that corporations are not

${ }^{65}$ See, e.g., Charles L. BlaCK, JR., A New BirTh OF Freedom 106 (1997).

${ }^{66}$ Newsom, supra note 3, at 738-40. Newsom's allegiance to the intent of the framers here conflicts with his failure to fully credit their natural rights perspectives on the Privileges or Immunities Clause.

${ }^{67}$ DAVID A.J. RICHARDS, CONSCIENCE AND THE CONSTITUTION 199 (1993); Aynes, Constricting the Law of Freedom, supra note 24, at 687. Richards argues that such disrespect has "discredited the very idea of the nationalization of human rights." RICHARDS, supra, at 201. For Richards, substantive due process has been a source for a somewhat haphazard implementation of human rights on a national scale; he thinks the Privileges or Immunities Clause could do this work more effectively and with more rhetorical legitimacy and success. Id. Newsom is "somewhat uncomfortable" with Richards' framing of the issue as one of human rights, Newsom, supra note 3, at $740 \mathrm{n} .473$, which is consistent with Newsom's general discomfort with natural rights theories of the Privileges or Immunities Clause. Indeed, Newsom comes close to a Bill-of-Rights-only approach to the Privileges or Immunities Clause that is rejected by Richards. RICHARDS, supra, at 202-04. 
citizens for the purpose of the Privileges or Immunities Clause. ${ }^{68}$ We cannot necessarily foretell the variety of changes possible in established incorporation doctrine should the Court begin evaluating each right anew as a privilege of United States citizenship. Such changes may be worthwhile, but they are not the stated motivations of those who advocate the revisionist readings and further discussion and consideration of the costs and benefits of the changes are warranted.

However, there are deeper flaws in the re-interpretation of SlaughterHouse. Scholars have already suggested shifting incorporationist arguments to the Privileges or Immunities Clause completely independent of any rereading of Slaughter-House. So long as the potential doctrinal changes are adequately confronted and addressed, such a move seems reasonable. Then why revisit Slaughter-House? The reason seems to be an effort to adopt Justice Miller's interpretation of the Fourteenth Amendment with the gloss of incorporation. Reinterpretation here is a means of modernizing the case to comport with currently accepted notions of constitutional justice, while leaving undisturbed the sleeping monsters of Justices Field and Bradley's fundamental rights.

By focusing on a re-reading of Slaughter-House that preserves incorporation, the revisionists sidestep the fundamental question of the legitimacy of the Court's reading of the Privileges or Immunities Clause. Even if we assume that Justice Miller would have accepted the incorporation of the Bill of Rights through the Privileges or Immunities Clause, does his division of citizenship into two realms, state and federal, and his steadfast relegation of the protection of fundamental rights to state citizenship, withstand analysis? Is it consistent with the understanding of the amendment within the congresses that drafted and then implemented the Amendment during Reconstruction? Is it the best interpretation, even in the context of when it was written? And if not, what impact did the Court's opinion have on the development, or lack thereof, of alternate readings of the Clause? The revisionists' focus on incorporation tends to distract them from dealing fully with these questions and their analysis of these issues is ultimately unsatisfactory.

Moreover, by focusing a modern interpretation of Slaughter-House on the incorporation issue, the revisionists are-whether intentionally or

${ }^{68}$ On both of these points, see Michael Kent Curtis, Resurrecting the Privileges or Immunities Clause and Revising the Slaughter-House Cases Without Exhuming Lochner: Individual Rights and Fourteenth Amendment, 38 B.C. L. REV. 1, 102-03 (1996) [hereinafter Curtis, Resurrecting the Privileges]. On the exclusion of corporations from the Privileges and Immunities Clause, see Paul v. Virginia, 75 U.S. (8 Wall.) 168, 178 (1869). 
not-perpetuating a potentially flawed reading of the Fourteenth Amendment and its history. There is far more ambiguity in the Amendment and its history on the issue of fundamental rights than the revisionists allow, and as we enter a stage of potential judicial reinterpretations of the Privileges or Immunities Clause, the ambiguity should not be downplayed for the sake of saving an incorporationist reading of a nonetheless flawed opinion.

\section{REVISIONISM AND THE MULTIPLE HISTORICAL MEANINGS OF THE PRIVILEGES OR IMMUNITIES CLAUSE}

There are primarily two interpretive routes that Slaughter-House obstructs and the revisionists are unwilling to re-open. First, as one of the revisionists has observed, there is a strong argument that the framers of the Fourteenth Amendment intended the Clause to encompass far more than mere incorporation of the Bill of Rights; they may well have intended to constitutionalize some version of a natural rights philosophy. ${ }^{69}$ Second, the framers may also have intended to enable Congress, through Section Five's enforcement powers, to interpret Privileges or Immunities in particular contexts and so give substance through legislation to the vague generalities of the Clause in ways broader than simple enforcement of the Supreme Court's definition of the Bill of Rights. ${ }^{70}$

Both of these (not mutually exclusive) options are worth exploring, yet none of the Slaughter-House revisionists addresses them fully. ${ }^{71}$ The

${ }^{69}$ Wildenthal, The Lost Compromise, supra note 4, at 1112 (Expansive review of Privileges or Immunities "is strongly supported by the legislative history."). Wildenthal ultimately rejects such an interpretation. Id. at 1112-15.

${ }^{70}$ For recent discussions regarding Section Five in this context, see Amar, Intratextualism, supra note 6, at 818-26; Caminker, supra note 6, at 1127; Stephen A. Engel, The McCulloch Theory of the Fourteenth Amendment: City of Boerne v. Flores and the Original Understanding of Section Five, 109 YALE L.J. 115 (1999); McConnell, Institutions and Interpretation, supra note 6, at 153.

${ }^{71}$ Some scholars argue for a revival of the Privileges or Immunities Clause but do not necessarily agree with the revisionists. For instance, David Richards proposes that the courts develop the natural rights approach to Privileges or Immunities. See RICHARDS, supra note 67, at 217-32. Most of these scholars focus on the judicial development of rights and privileges. Professor Rich raises the possibility of congressional development. See generally Rich, Privileges or Immunities: The Missing Link, supra note 6, and Rich, Taking "Privileges or Immunities" Seriously, supra note 6 . I would be remiss not to say that I certainly do not expect scholars to address every possibility for the Privileges or Immunities Clause in each Article. Exploration of an alternative reading of Slaughter-House is a large enough chunk to chew; Newsom and Wildenthal each do an excellent job 
problem with focusing on incorporation issues generally, and focusing in particular on Slaughter-House, is that we blind ourselves to the possibility that a little-used, underdeveloped Clause of the Constitution that is grounded in the concept of citizenship may well have potential far different from a jurisprudence conceived around substantive due process. What it means to be a citizen, and which political body should properly define and elaborate the privileges of citizenship, may not parallel the issues raised by due process and equal protection.

\section{A. Revisionist Fears of the End of Federalism}

Because Newsom's re-reading of Slaughter-House most clearly rejects a fuller exploration of the Privileges or Immunities Clause, I will turn to it first. Newsom essentially adopts Justice Miller's false dichotomy between a restrictive interpretation of the Clause and a no-holds-barred grant to the judiciary to impose its own pet rights under the guise of a natural rights philosophy ${ }^{72}$ As mentioned above, Newsom does a nice (if occasionally overstated) job illustrating that Miller's opinion does not necessarily box the Privileges or Immunities Clause into a trivial restatement of preFourteenth Amendment rights. Despite the hints in the opinion that Bill of Rights freedoms remain viable as national privileges and immunities, Justice Miller was clearly bothered by the free-ranging alternative he read in the dissents. He expressed concern about both the destruction of traditional federalism and judicial activism. He explicitly feared congressional power to "pass laws in advance" of state violations of the Amendment and the Court's power to become a "perpetual censor" over state legislation. ${ }^{73}$ While he admitted that " $[t]$ he argument ... is not always the

addressing the topics they set out to investigate. However, the revisionists' general downplay of Natural Rights readings and their omission of the potential role of Congress need to be explored.

72 Newsom asserts that he in fact rejects a false dichotomy interpretation of Slaughter-House. Newsom, supra note 3, at 666. Newsom argues that most scholars read Miller's opinion as choosing between a trivial interpretation of the Privileges or Immunities Clause and a " 'self-executing source of a full panoply of legal rights (including business freedoms) ....' Id. (citation omitted). While Newsom may be right that Miller did not view the Privileges or Immunities Clause as trivial, his reading of Miller's opinion-probably the most charitable reading possible-nonetheless sets forth a dichotomy between possible incorporation of some of the Bill of Rights and far-ranging judicial creation of rights. By portraying his own reading as the middle ground, Newsom ignores the large tract of land between his poles of interpretation.

${ }^{73}$ The Slaughter-House Cases, 83 U.S. (16 Wall.) 36, 77-78 (1872). 
most conclusive which is drawn from the consequences urged against the adoption of a particular construction of an instrument[,]" he asserted that:

[W] hen, as in the case before us, these consequences are so serious, so far-reaching and pervading, so great a departure from the structure and spirit of our institutions; when the effect is to fetter and degrade the State governments by subjecting them to the control of Congress, in the exercise of powers heretofore universally conceded to them of the most ordinary and fundamental character; when in fact it radically changes the whole theory of the relations of the State and Federal governments to each other and of both these governments to the people; the argument has a force that is irresistible, in the absence of language which expresses such a purpose too clearly to admit of doubt. ${ }^{74}$

For Miller, the only option other than his restrictive view of the Clause was one that destroyed federalism and dangerously empowered the Court. The very starkness of the alternatives, argued Miller, enabled him to accept what he considered an otherwise weak ("not always most conclusive") argument: the parade of anti-federalism horribles. He saw no middle ground. $^{75}$

Nor does Newsom. He contends that Miller "sought to maintain some semblance of a federal-state balance of power"76 and that Miller believed

${ }^{74}$ Id. at 78 (emphasis added).

${ }^{75} \mathrm{Id}$.

${ }^{76}$ Newsom, supra note 3, at 707. Newsom then overstates his case immediately following the above-quoted passage: "Hence, [Miller's] opinion in SlaughterHouse acknowledged the incorporation of the most uniquely federal of individual rights, including many of those enumerated in the first eight amendments, but refused the federalization of common-law rights." Id. Newsom wrongly states that Miller's opinion acknowledges incorporation of most of the Bill of Rights. The best one can say from the text is that the Court mentions the "right to peaceably assemble and petition for redress of grievances." Slaughter-House, 83 U.S. (16 Wall.) at 79. Just a few pages earlier, Newsom characterizes the opinion as follows: "there is nothing in Slaughter-House that precludes a reading of the Privileges or Immunities Clause as incorporating the Bill of Rights. In fact, viewed in proper context, Miller's majority opinion in Slaughter-House seems quite possibly to contemplate incorporation." Newsom, supra note 3, at 683. This latter avoidance of overstatement accurately captures Newsom's valuable point that the opinion does not "preclude" incorporation, as well as his thesis that one can read a context (mostly based on Newsom's careful reading of Miller's jurisprudence) in which it does more. It is not clear why Newsom converts his cautious speculation (note the words: "context," "seems," "possibly," and "contemplate") into a bold assertion of 
that "the transfer of authority over the definition and protection of individual rights was not wholesale." between the States and the National Government would be practically abolished." ${ }^{78}$ In these statements, Newsom, like Miller, sees the restrictive interpretation of the Privileges or Immunities Clause as a final dike against the nationalism flood. Near the end of his article, Newsom cites Justice Thomas for the proposition that courts might employ the Privileges or Immunities Clause to engage in the dangerous activity of inventing new rights, which Newsom identifies as "very legitimate fears" and "grave concerns." Wildenthal also expresses this concern for upsetting the "fundamental federal-state balance of power."

express incorporation ("acknowledged" incorporation of "many" of the Bill of Rights) a few pages later.

${ }^{77}$ Newsom, supra note 3, at 692 .

${ }^{78}$ Id. (quoting 2 CharLes WARREN, THE SUPREME COURT IN UNITED STATES HISTORY 547 (rev. ed. 1926)).

${ }^{79}$ Id. at 735 (citing Saenz v. Roe, 526 U.S. 489 (1999) (Thomas, J. dissenting)). Newsom also cites Lawrence Tribe to support this point, but he quotes Tribe partially and out of context. Here is the statement Tribe makes, with the portions quoted by Newsom in italics: "invoked in its (until recently) virgin state, the Privileges or Immunities Clause, some might fear, could invite judicial decisionmaking untethered by precedent and untamed by tested principle and might thereby undermine the legitimacy both of the decision relying upon it and of the courts invoking it." TRIBE, supra note 24, §§ 7-6, at 1328-29; Newsom, supra note 3, at 735. The omitted language ("some might fear") makes plain that Tribe castes this statement in the voice of others - judges and scholars, it turns out - and does not necessarily agree with it. In his subsequent discussion, Tribe makes clear his position that it is wrong to assume courts would view the Clause as "carte blanche to enact their own policy preferences" or use it arbitrarily. TRIBE, supra note $24, \S \S 7-6$, at 1329.

${ }^{80}$ Wildenthal, The Lost Compromise, supra note 4, at 1067. See also Palmer, supra note 4, at 741 (Miller's was a "middle ground"); id. at 743 (dissents would "change the entire relationship between federal and state governments."); id. at 757 (dissenters "are called Radical Republicans for a reason."). Wildenthal also contends that "clearly [the Fourteenth Amendment] was not meant to obliterate state power or radically alter the federal-state balance." Wildenthal, The Lost Compromise, supra note 4, at 1114. See also McConnell, Institutions and Interpretation, supra note 6, at 174 (Republicans "were not prepared for [a radical] transformation in the balance of power between the central government and the states."). This sounds much like Miller's opinion, which Wildenthal then quotes favorably on this point. Wildenthal, The Lost Compromise, supra note 4. As evident in my discussion below, I think it is far from "clear" that the Fourteenth Amendment was not meant to alter significantly federal-state relations. In 
The fears expressed by Miller, and echoed by Newsom and others, sound like the fears of a sea traveler confronting unfamiliar waters. The choice quickly becomes one between steering a course already charted or venturing onward into the sea of one's imagined monsters. The monster for Miller was expanded federal powers, and the charted path was antebellum federalism. The revisionist re-reading of Miller's opinion cannot avoid the fact that Miller clearly and forcefully chose to steer "with a steady and even hand" along the course of antebellum federalism, making a firm statement of his position in the final paragraph of the opinion:

But whatever fluctuations may be seen in the history of public opinion on this subject during the period of our national existence, we think it will be found that this court, so far as its functions required, has always held with a steady and an even hand the balance between State and Federal power, and we trust that such may continue to be the history of its relation to that subject so long as it shall have duties to perform which demand of it a construction of the Constitution, or of any of its parts. ${ }^{81}$

In the face of a Civil War that deeply tested the antebellum understanding of federalism and a series of constitutional amendments that had restructured this federalism, such an effort to turn back the clock would seem fanciful had it not been so successful. It denies any revolutionary effect to the war and the spate of congressionally empowering constitutional Amendments and national legislation of the 1860s and 1870s. Instead, it substitutes a mild bromide to remedy the constitutional ills that helped cause a great and horrific war. ${ }^{82}$ Thus Justice Swayne's response to

particular, congressional enactments of the period, which relied in large part upon Congress' power under the Fourteenth Amendment, were a significant, and one could argue "radical," change in federalism. The current Court invokes concerns with congressional power under Section Five of the Fourteenth Amendment similar to the revisionists. See United States v. Morrison, 529 U.S. 598, 620 (2000). The Court oddly expresses more concern for the framers of the original Constitution than for the views of the framers of the Fourteenth Amendment which, after all, is the portion of the Constitution being interpreted.

${ }^{81}$ Slaughter-House, 83 U.S. (16 Wall.) at 82.

${ }^{82}$ James McPherson, among others, describes this war and post-war period as a "second American revolution" in part because of the nationalization of powers over individuals. See JAMES M. MCPHERSON, ABRAHAM LINCOLN AND THE SECOND AMERICAN REVOLUTION, at 12-13, 140-52 (1991). See also Robert J. Kaczorowski, Revolutionary Constitutionalism in the Era of the Civil War and Reconstruction, 61 N.Y.U. L. REV. 863, $871-99$ (1986) [hereinafter Kaczorowski, 
Justice Miller: "These amendments [the Thirteenth, Fourteenth, and Fifteenth] are a new departure, and mark an important epoch in the constitutional history of the country. They trench directly upon the power of the States, and deeply affect those bodies. They are, in this respect, at the opposite pole from the first eleven." 83 And further: "[t]hese amendments are all consequences of the late civil war. The prejudices and apprehension as to central government which prevailed when the Constitution was adopted were dispelled by the light of experience. ... It is objected that the power conferred is novel and large. The answer is that the novelty was known and the measure deliberately adopted." ${ }^{84}$ Ultimately, the SlaughterHouse revisionists perform the contemporary equivalent of Justice Miller's feat: they drain the Privileges or Immunities Clause of its force by limiting

Revolutionary Constitutionalism]; Donald G. Neiman, From Slaves to Citizens: African-Americans, Rights Consciousness, and Reconstruction, 17 CARD. L. REV. 2115, 2115-17 (1996). But cf. Michael Les Benedict, Preserving Federalism: Reconstruction and the Waite Court, 1978 SUP. CT. REV. 39, 57-62 (arguing that Miller's opinion was a reasonable balancing of post-war nationalism and commonly held ideals of federalism); Earl Maltz, Reconstruction Without Revolution: Republican Civil Rights Theory in the Era of the Fourteenth Amendment, 24 Hous. L. REv. 221, 230-36 (1987) and id. at 233 ("The Civil War wrought no great change in the attitudes of Americans toward the possibility of being governed primarily by the federal government.").

${ }^{83}$ Slaughter-House, 83 U.S. (16 Wall.) at 126 (Swayne, J., dissenting).

${ }^{84}$ Id. at 128-29 (Swayne, J., dissenting). Some might find Swayne romantically, even absurdly, sanguine about national power. Certainly Swayne did claim that the provisions of Section One of the Fourteenth Amendment "are a bulwark of defense, and can never be made an engine of oppression" and that the power granted "is beneficent in its nature, and cannot be abused." Id. And certainly this is optimistic. But given the choice, in 1873, between Swayne's optimism about federal powers as yet little tested or Miller's desire to return as nearly as possible to a state-based, antebellum federalism with a long and recent history of horrible abuses - against slaves, free blacks, and abolitionist whites-one wonders why Miller's choice seems so sensible to revisionists. Republicans in fact had articulated an unromanticized and very plausible version of Swayne's argument. See CoNG. GLOBE, 42d Cong., 1st Sess. 334-35 (1871) (Representative Hoar, debating the Enforcement Act, argued that the actual deprivation of rights by states was far more problematic than potential federal abuses, and concluded: "The principle danger that menaces us to-day is from the effort within the States to deprive considerable numbers of person the civil and equal rights which the General Government is endeavoring to secure to them."). Revisionists give insufficient attention to this argument. 
it to the rights expressed in Slaughter-House plus the already incorporated portions of the Bill of Rights. ${ }^{85}$

Slaughter-House revisionists do not necessarily think that this is what they are doing. Newsom, for instance, purports to allow room for additional privileges through Justice Miller's rubric of whether the rights "owe their existence to the Federal government, its National character, its Constitution, or its laws," ${ }^{36}$, with a focus primarily on the "National character" prong. But as far as we can tell from Newsom, this gets us only the right to travel, which itself has a substantial basis in constitutional language other than the Privileges or Immunities Clause and is certainly no neophyte in the pantheon of national privileges and immunities (it arguably existed prior to the Fourteenth Amendment) ${ }^{87}$

${ }^{85}$ To the extent that the revisionists so limit the Privileges or Immunities Clause, they are doing little more than what Justice Black urged over fifty years ago: incorporating the Bill of Rights but limiting the privileges and immunities of national citizenship to those rights clearly enumerated in the text of the Constitution. See, e.g., Adamson v. California, 332 U.S. 46, 68 (1947) (Black, J., dissenting). See RICHARDS, supra note 67, at 202 (discussing Black's interpretive positivism in limiting privileges and immunities to textually enumerated rights).

${ }^{86}$ Slaughter-House, 83 U.S. (16 Wall.) at 79; Newsom, supra note 3, at 736.

${ }^{87}$ In Saenz $v$. Roe, the Court tried to pin the previously floating right to travel to specific language in Constitution. Saenz v. Roe, 526 U.S. 489, 500-04 (1999). See also Douglas G. Smith, A Return to First Principles? Saenz v. Roe and the Privileges or Immunities Clause, 2000 UTAH L. REV. 305, 308 nn.14 \& 15 [hereinafter Smith, A Return to First Principles?] (discussing shifting basis for the right to travel prior to Saenz). The Saenz Court, however, itself shifts between the Privileges or Immunities Clause and the Citizenship Clause in defining the right to travel and reside in a particular state, see Saenz, 526 U.S. at 502 n. 15, 503, 506-07, 510-11, n.27. Newsom locates the Saenz Court's right to travel in Miller's "National character" of the Federal government, Newsom, supra note 3, at 735, and omits any discussion of the concept of national citizenship so important to the Saenz Court's opinion. Saenz, 526 U.S. at 506-07 and 510-11. In any event, the right to travel has ample basis in other provisions, as discussed by the Court in Shapiro v. Thompson, 394 U.S. 618, $630 \mathrm{n} .8$ (1969), and arguably pre-dates the Fourteenth Amendment in an opinion written by Justice Miller in Crandall $v$. Nevada, 73 U.S. (6 Wall.) 35 (1868). Indeed, one suspects that Justice Miller's inclusion of the "National character" of the federal government as a source of national privileges, followed immediately by citation to Crandall, was itself an attempt to further justify his creation of rights not based on specific text in Crandall, and moor that approach to the subsequently enacted Fourteenth Amendment. In Slaughter-House, Miller also posits a version of the right to travel in the right of a United States citizen to "become a citizen of any State of the Union by a bona fide residence therein." Slaughter-House, 83 U.S. (16 Wall.) at 
Wildenthal advocates this moderation as a selling point of his approach ${ }^{88} \mathrm{He}$ admits that his view errs "on the side of conservative textualist principles in a way that would not upset, as the Amendment's opponents feared, the fundamental federal-state balance of power." ${ }^{189} \mathrm{He}$ further acknowledges the possibility that the framers of the Amendment, or at least some of them, intended the clause to create a wide range of unenumerated rights, much as Justice Bradley argued in dissent. ${ }^{90}$ Wildenthal contends, however, that his incorporationist-only reading of the Clause is more closely tied to the constitutional text, and that the Court's effort to avoid "an untrammeled nationalist interpretation" of the Amendment was consistent with many contemporaries, including those in Congress, who did not want to significantly alter the federal-state balance. ${ }^{11}$

\section{B. Misreading the Fourteenth Amendment and its History}

The problem with the reinterpreted, incorporationist view of SlaughterHouse is that it overlooks historically significant variations for determining the content of the Privileges or Immunities Clause beyond the Bill of Rights: the natural rights theory of many Framers of the Amendment and the role for Congress under Section Five. Revisionists largely dismiss the former and ignore the latter.

As to the first point, there is significant evidence that many of the framers of the Amendment who drafted and debated the Privileges or Immunities Clause intended to have it include natural rights concepts. This

80. As Douglas Smith has pointed out, the Court in Saenz was really doing nothing new in identifying the right to travel as a privilege of citizenship. See Smith, $A$ Return to First Principles?, supra, at 317-19. On Saenz generally, see Lawrence H. Tribe, Saenz Sans Prophecy: Does the Privileges or Immunities Revival Portend the Future-Or Reveal the Structure of the Present?, 113 HARV. L. REV. 110 (1999).

${ }^{88}$ Wildenthal argues that the Supreme Court will eventually need to address some of the as yet unincorporated rights of the Bill of Rights (and may even rethink some currently incorporated rights), and that the Court's determination of the basis for incorporation will make a difference in the outcome of these decisions. Wildenthal, The Lost Compromise, supra note 4, at 1056. See also Wildenthal, The Road to Twining, supra note 62, at 1525-30 (discussing the Court's long acceptance of the basic incorporation of most of the Bill of Rights).

${ }^{89}$ Wildenthal, The Lost Compromise, supra note 4, at 1066-67.

${ }^{90} \mathrm{Id}$. at 1112 .

${ }^{91}$ Id. at 1112-13, 1170-72. 
position has been well documented elsewhere, ${ }^{92}$ and I will only summarize the argument here. First, the drafters and supporters of the Amendment often spoke of broad, natural rights concepts. Representative Bingham, the primary drafter of Section One of the Amendment, stated that the Amendment would enable the people of the nation "to protect by national law the privileges and immunities of all the citizens of the Republic and the inborn rights of every person within its jurisdiction" and that the privileges and immunities "include, among other privileges, the right ... to be protected in life, liberty, and property." 93

Senator Howard, who presented the Amendment to the full Senate on behalf of the Joint Committee that drafted the Amendment, set forth the clearest, most elaborate definition of the Clause. In doing so he included the rights listed in the first eight amendments of the Bill of Rights, a point often made by advocates of incorporation, but he also stated that such rights were non-exhaustive because privileges and immunities "are not and cannot be fully defined in their entire extent and precise nature. ${ }^{94}$ This at the very least indicates that Howard did not view the Clause as limited to the Bill of Rights. More significantly, Howard began his explication of the definition of the Privileges or Immunities Clause by reading a long passage from

92 JACOBUS TENBROEK, EQUITY UNDER LAW 209-39 (1965) (revised edition of THE ANTISLAVERY ORIGINS OF THE FOURTEENTH AMENDMENT (1951)); Daniel A. Farber \& John E. Muench, The Ideological Origins of the Fourteenth Amendment, 1 CONST. COMMENT. 235 (1984); Kaczorowski, Revolutionary Constitutionalism, supra note 82, at 890-95; Douglas G. Smith, Natural Law, Article IV, and Section One of the Fourteenth Amendment, 47 AM. U. L. REv. 351 (1997) [hereinafter Smith, Natural Law]; Douglas G. Smith, The Privileges and Immunities Clause of Article IV, Section 2: Precursor of Section 1 of the Fourteenth Amendment, 34 SAN DIEGO L. REV. 809, 881 (1997) [hereinafter Smith, The Privileges and Immunities Clause]. For one of the more extensive statements of the natural rights foundation of congressional power during reconstruction, see CONG. GLOBE, 39th Cong., 1st Sess. 1119 (1865) (statement of Rep. Wilson). See also sources cited and discussed in Robert J. Kaczorowski, To Begin the Nation Anew: Congress, Citizenship, and Civil Rights After the Civil War, 92 AM. HISTORICAL REV. 45, 48 n.10 (1987) [hereinafter Kaczorowski, To Begin the Nation Anew] and Kaczorowski, Revolutionary Constitutionalism, supra note 82, at 878 n.58.

${ }^{93}$ CoNG. GLOBE, 39th Cong., 1st Sess. 2542 (1866) (statement of Rep. Bingham). For an excellent presentation of Bingham's views, see Richard L. Aynes, On Misreading John Bingham and the Fourteenth Amendment, 103 YALE L.J. 57 (1993) [hereinafter Aynes, On Misreading John Bingham]. See also Richard L. Aynes, The Antislavery and Abolitionist Background of John A Bingham, 37 CATH. U.L. REV. 881 (1988).

${ }_{94}$ CONG. GLOBE, 39th Cong., 1st Sess. 2765 (1866) (statement of Sen. Howard). 
Corfield v. Coryell ${ }^{95}$ In that case, as quoted by Howard, Justice Washington, riding circuit, interpreted the definition of privileges and immunities under Article IV, Section Two of the Constitution. ${ }^{96}$ Significantly, the framers of the analogous clause in the Fourteenth Amendment frequently referred back to Article IV and particularly to Justice Washington's discussion of privileges and immunities. The importance of the quote for the purposes of interpreting the Fourteenth Amendment, however, lies primarily in Senator Howard's use of it to explain the similar language of the Privileges or Immunities Clause. In Corfield, Justice Washington set forth "fundamental" privileges belonging "of right to the citizens of all free governments," and gave an illustrative list that goes well beyond (and does not itself include) the Bill of Rights. There is certainly good reason to view Washington's definition as based in natural rights, ${ }^{97}$ and even better reason

\footnotetext{
${ }^{95}$ Corfield v. Coryell, 6 F. Cas. 546 (C.C.E.D. Pa. 1823) (No. 3230).

${ }^{96}$ According to Justice Washington, the Privileges and Immunities Clause encompassed:

"[T]hose privileges and immunities which are, in their nature, fundamental; which belong, of right, to the citizens of all free governments; and which have, at all times, been enjoyed by the citizens of the several states which compose this Union, from the time of their becoming free, independent, and sovereign. What these fundamental rights are, it would perhaps be more tedious than difficult to enumerate. They may, however, be all comprehended under the following general heads: Protection by the government; the enjoyment of life and liberty, with the right to acquire and possess property of every kind, and to pursue and obtain happiness and safety; subject nevertheless to such restraints as the government may justly prescribe for the general good of the whole. The right of a citizen of one state to pass through, or to reside in any other state, for purposes of trade, agriculture, professional pursuits, or otherwise; to claim the benefit of the writ of habeas corpus; to institute and maintain actions of any kind in the courts of the state; to take, hold and dispose of property, either real or personal; and an exemption from higher taxes or impositions than are paid by the other citizens of the state; may be mentioned as some of the particular privileges and immunities of citizens, which are clearly embraced by the general description of privileges deemed to be fundamental: to which may be added, the elective franchise, as regulated and established by the laws or constitution of the state in which it is to be exercised. These, and many others which might be mentioned, are, strictly speaking, privileges and immunities."

Id. at 551-52.

${ }^{97}$ Compare Harold M. Hyman \& William M. WieceK, Equal Justice UNDER LAW: CONSTITUTIONAL DEVELOPMENTS 1835-1875, at 407 (1982) (referring to the "natural law catalog" of Corfield) and TRIBE, supra note 24 , $\S \S$
} 
to think that the use of the Corfield quote to define the Fourteenth Amendment version of privileges and immunities was meant to illustrate the far-ranging, natural rights meaning of the Privileges or Immunities Clause itself. While the precise application of these Corfieldian rights to particular cases remains difficult (e.g., does Justice Washington's invocation of the rights of life, liberty, property, and the pursuit of happiness encompass the anti-monopoly, free labor position of the dissenters in Slaughter-House?), it becomes hard to argue that Senator Howard would have supported a Bill-of-Rights-only limitation to the Privileges or Immunities Clause. Moreover, Howard's characterization was not challenged in the Senate or the House, indicating that his definition should carry some interpretive weight. ${ }^{98}$

These two statements are supported by repeated references in the debates to both Corfield and the Privileges and Immunities Clause of Article IV. As David Farber and John Muench have argued, fundamental rights were the cornerstone of what the framers were protecting with the Thirteenth and Fourteenth Amendments and Reconstruction legislation. ${ }^{99}$ Natural law provided a wellspring for many anti-slavery Republicans both before the Civil War and during the framing of the Thirteenth Amendment. ${ }^{100}$ Farber and Muench also perceptively note that the Republican rhetoric shifted after the War to an emphasis on the rights of national citizenship, but that this rhetoric was itself based on the same

14-13 ("Corfield can best be understood as an attempt to import the Natural Rights doctrine into the Constitution by way of the Privileges and Immunities Clause ...") with Fox, supra note 24, at 480-84 (suggesting that Justice Washington's limitations on the rights listed in Corfield rendered the fundamentalness of those rights rather thin). Ultimately, the most significant aspect of Corfield is not how one should properly read. Justice Washington, but how the framers of the Thirteenth and Fourteenth Amendments read the case and implemented their own interpretation through the Amendments and enforcing legislation. See, e.g., CURTIS, No STATE SHALL ABRIDGE, supra note 24, at 114-15; HYMAN \& WIECEK, supra, at 407, 435. Cf. EARL M. MaLTZ, Civil RIGHTS, THE ConstituTION, AND CONGRESS, 1863-1869, at 106-09 (1990) [hereinafter MALTZ, CIVL RIGHTS]. My own view is that some framers believed Corfield supported federalized natural rights. But cf. Aynes, Constricting the Law of Freedom, supra note 24, at 651 (arguing that "fundamental" as used in Corfield and by the framers referred to constitutional, not natural, rights).

${ }^{98}$ See AMAR, THE BLL OF RIGHTS, supra note 24, at 167-87; CURTIS, No STATE SHALL ABRIDGE, supra note 24, at 91.

${ }^{99}$ See Farber \& Muench, supra note 92.

${ }^{100}$ Id. at 246-59. 
natural law principles that had inspired the Thirteenth Amendment; American citizenship inherently encompassed natural rights principles. ${ }^{101}$

Newsom tries to deflect this position by asserting that the framers of the Fourteenth Amendment did not intend to include natural rights as privileges and immunities of national citizenship. Newsom relies primarily on Professor Maltz's study of this issue, ${ }^{102}$ yet Newsom misconstrues both the framers and Professor Maltz. Newsom, citing Maltz, posits that the refusal of the Joint Committee of Fifteen (drafted the Amendment) to endorse the proposal of reformer Robert Dale Owen, which referred to "civil rights," combined with the eventual congressional agreement on Representative Bingham's "Privileges or Immunities" phrasing, indicates that Corfieldian state-based civil rights were not part of the federal Privileges or Immunities. Newsom argues that "civil rights" must have been understood to include natural rights in a way that "Privileges or Immunities" did not. But Maltz does not attribute the change to such a singular cause. Maltz does say that "the Bingham substitute must have been aimed at a narrower class of rights than the Owen proposal." 103 This conclusion is based on Maltz's careful dissection of the voting patterns of the Joint Committee and his evaluation of their political leanings. While his analysis carries weight, it remains speculative since, as he admits, there is no record of the discussion of the Joint Committee to confirm or reject a hypothesis. ${ }^{104}$ Moreover, Maltz himself does not argue that the Privileges or Immunities formulation clearly rejected Corfieldian rights. By "narrower class of rights," Maltz refers primarily to the fact that civil rights might have included voting rights, whereas Privileges or Immunities did not. ${ }^{105}$ Maltz also mentions that Privileges or Immunities would likely have been taken to encompass "fundamental" rights, although "fundamental" was

${ }^{101}$ Id. at 262. See, e.g., CONG. GLOBE, 39th Cong., 1st Sess. 1757 (1865) (statement of Sen. Trumbull) (responding to President Johnson's veto of the Civil Rights Bill, Sen. Trumbull argued that the Bill protected "inherent, fundamental rights which belong to free citizens or free men in all countries .... The right of American citizenship means something.").

${ }^{102}$ Newsom, supra note 3, at 699-700.

${ }^{103}$ Earl M. Maltz, The Fourteenth Amendment as Political CompromiseSection One in the Joint Committee on Reconstruction, 45 OHIO ST. L.J. 933, 964 (1984) [hereinafter Maltz, The Fourteenth Amendment] (emphasis added). For the Journal of the Joint Committee, see BENJAMIN B. KENDRICK, THE JOURNAL OF THE JOINT COMMITTEE OF FIFTEEN ON RECONSTRUCTION 37-129 (1914) (1969, Negro University Press).

${ }^{104}$ Maltz, The Fourteenth Amendment, supra note 103, at 949-50.

${ }^{105}$ Id. at 967. 
probably more narrow than "civil" (again, because of the non-inclusion of voting rights). Ultimately, Maltz confirms the point that there was uncertainty within Congress about what the phrase "privileges and immunities" did encompass; he does not go so far as to contend that Corfieldian rights were off the table. ${ }^{106}$ When put alongside the evidence that some members of Congress did see the Clause as encompassing Corfieldian rights, Newsom's analysis on this point seems rather weak. ${ }^{107}$

A natural rights reading of the Privileges or Immunities Clause also receives potential support from the Civil Rights Act of 1866, passed over President Johnson's veto, and simultaneous with the drafting of the Fourteenth Amendment. As mentioned above, Congress drafted the Fourteenth Amendment in part to give constitutional legitimacy to the Civil Rights Act. That Act declared that all citizens of the United States (defined by birth):

${ }^{106} \mathrm{Cf}$. MALTZ, CIVIL RIGHTS, supra note 97, at 107 (Corfield was one of the sources used by framers of the Privileges or Immunities Clause); id. at 114-15 (noting that Senator Howard defined privileges or immunities as both the Bill of Rights and "fundamental" rights, and that Representative Bingham sometimes linked privileges and immunities to natural rights and sometimes to the Bill of Rights); id. at 118-20 (framers had particular desire to remove the right to vote from privileges and immunities concepts).

${ }^{107}$ Newsom also presents a misleading interpretation of Representative Bingham's vote against the Civil Rights Bill. Newsom argues that Bingham's vote against the Bill was based in part on his fear that the Bill would grant too much power in the federal government. Newsom, supra note 3, at 700 n.276. Newsom even goes so far as to equate Bingham's simultaneous endorsement of the Fourteenth Amendment and rejection of the Civil Rights Bill as support for Justice Miller's views in Slaughter-House. Id. This is curious, considering that Bingham voted in favor of the re-enactment of the Civil Rights Act in 1870, a re-enactment which occurred in part to meet Bingham's main concern in 1866 that the Fourteenth Amendment itself was necessary to grant Congress the power to enact the Civil Rights Bill. 41st Cong., 2d Sess. (May 27, 1870) (House vote over final version of Enforcement Act containing Civil Rights Act). Bingham also enabled the enactment of the 1866 Bill over Johnson's veto by pairing his vote to enable a two-thirds majority override, despite his misgivings about its constitutionality. CONG. GLOBE, 39th Cong., 1st Sess. 1861 (1866). While it is not clear how far Bingham would have wanted Congress or the Courts to go in enforcing a broad natural rights theory under the Privileges or Immunities Clause, one cannot use Bingham's opposition to the Civil Rights Bill as evidence of a no-natural rights interpretation of that Clause. For a more plausible reading of Bingham's opposition to the 1866 Act, as based on Bingham's belief that the Fourteenth Amendment was necessary to give Congress the power to pass the act, see Aynes, On Misreading John Bingham, supra note 93, at 72-73. 
shall have the same right in every.state and territory in the United States, to make and enforce contracts, to sue, be parties, and give evidence, to inherit, purchase, lease, sell, hold, and convey real and personal property, and to full and equal benefit of all laws and proceedings for the security of person and property, as is enjoyed by white citizens, and shall be subject to like punishment, pains, and penalties, and to none other, any law, statute, ordinance, regulation, or custom to the contrary notwithstanding. ${ }^{108}$

Congress here enacted a national citizenship consisting of defined rights and privileges. ${ }^{109}$ The language of the Act leaves little doubt that Congress was doing something other than enforcing the Bill of Rights under the guise of citizenship rights: the subject rights included contract, property, and court access, not the rights to bear arms, assemble, or speak. Since Congress viewed the Fourteenth Amendment as enabling it to do the type of things it had done in the Civil Rights Act, it is logical to see the Act as being one particular instantiation of the Privileges or Immunities Clause. There is admittedly room for debate over whether Congress understood this Act to assert only a national privilege to equal treatment in relation to the listed fundamental rights, or instead saw the particular fundamental rights mentioned as themselves national privileges. The problem with SlaughterHouse revisionism, however, is that it tends to assume the equality-only reading and ignores the evidence of a fundamental rights reading.

The Slaughter-House revisionists might reply that the Civil Rights Act is self-evidently about equal treatment. Kevin Newsom, for instance, quotes the act and asserts, with little discussion, that the fundamental rights reading of Justice Field is plainly wrong. ${ }^{110}$ This being the case, there is no need to consider equality as an additional citizenship privilege since it is itself enumerated in the Fourteenth Amendment's Equal Protection Clause. ${ }^{11}$ This is a plausible reading of the Act, but it is not the only one. The equality-only reading of the Act ignores important evidence that the Act was intended to grant equality of something. That "something" was a baseline of "white" rights, a guaranty of absolute rights as already

${ }^{108}$ Civil Rights Act, 14 Stat. 27 (1866).

${ }^{109}$ See Fox, supra note 24, at 493-94; Kaczorowski, Revolutionary Constitutionalism, supra note 82 , at 884-90.

${ }^{110}$ Newsom, supra note 3, at 663. See also id. at 684-85.

"I' For another example of the equality or antidiscrimination reading of the Act, see MALTZ, CIVIL RIGHTS, supra note 97, at 66-67. For a rejection of the equalityonly reading, see CURTIS, No STATE SHALL ABRIDGE, supra note 24, at 72-73. 
evidenced by the rights whites possessed. Under this alternative reading, mere equality was insufficient (and even meaningless and incomprehensible in a free society) without reference to some baseline of natural rights. The Act did not state merely that blacks would have "whatever rights the State chooses to grant to other persons," but instead that blacks (and all other citizens) would have "the same right . . . [to contract, property, security, etc.] as is enjoyed by white citizens . . .."112 The rights were already enjoyed by whites because they were natural rights; whites were the universalizing race. The white citizen had always been the standard for the highest level of protection of these rights, and so long as popular government existed, whites' political protections should ensure that whites would not deny themselves these basic rights. Thus, stating the guaranty as one of equality to whites was sufficient to secure those fundamental rights for everyone. ${ }^{113}$

${ }^{112}$ Civil Rights Act, 14 Stat. 27 (1866) (emphasis added). The language "as is enjoyed by white citizens" was added to the Bill in the House with little debate to assist our interpretation. CONG. GLOBE, 39th Cong., 1st Sess. 1115 (1865). A similar point can be made by observing that the Act guaranteed the "full and equal benefit of all laws or proceedings for security of person and property." See Michael Kent Curtis, Free Speech, "The People's Darling Privilege" 371 (2000) [hereinafter CURTIS, FREE SPEECH]; Curtis, Resurrecting the Privileges, supra note 68, at 54; Aviam Soifer, Protecting Civil Rights: A Critique of Raoul Berger's History, 54 N.Y.U. L. REV. 651, 683-84 (1979).

${ }^{113}$ Thus, Professor McConnell is not necessarily right to paraphrase the Act as stating: "If a state provided these rights to its 'white citizens,' it had to provide the 'same right' to all citizens." See Michael W. McConnell, Originalism and the Desegregation Decisions, 81 VA. L. REV. 947, 958 (1995) [hereinafter McConnell, Originalism]. There is no conditional "if" in the Act. It simply states that blacks "shall have the same right [to contract, property, etc.] . . as is enjoyed by white citizens." I read this as mandatory, not conditional, language that assumes an established right and commands equal access to that right. Professor McConnell's paraphrase obviously indicates that he reads the language as conditional. For other readings contrary to mine, see MALTZ, CIVL RIGHTS, supra note 97, at 66-67 (reading the language as McConnell later does, and also suggesting a political benefit to the language as avoiding the necessity of federal definitions of rights); Earl M. Maltz, The Constitution and Nonracial Discrimination: Alienage, Sex, and the Framers' Ideal of Equality, 7 CONST. COMMENT. 251, 265 (1990) [hereinafter Maltz, The Constitution and Nonracial Discrimination] (use of "whites" was a matter of convenience). Ultimately, I think it is unlikely that Republicans attempting to combat the Black Codes would have considered the elimination of fundamental rights such as contract to be consistent with the Act or basic 
This reading is also consistent with some evidence of what AfricanAmericans took to be the meaning of freedom and citizenship. As one Union League convention in Alabama wrote:

[W] c claim exactly the same rights, privileges, and immunities as are enjoyed by white men - we ask nothing more and will be content with nothing less. ... The law no longer knows white nor black, but simply men, and consequently we are entitled to ride in public conveyances, hold office, sit on juries and everything else which we have in the past been prevented from doing solely on the ground of color. ... ${ }^{114}$

To these authors, privileges and immunities include all the things that make people (or, in the gendered language and law of the period, men) participating and free citizens. At least some contemporaneous public understandings of the Act included a baseline of affirmative natural (white) rights.

Several statements in the congressional debates support such a reading. Senator Trumbull, when first discussing the possibility of civil rights legislation in December 1865, stated upon the imminent adoption of the Thirteenth Amendment:

If the information from the South be that the men whose liberties are secured by it are deprived of the privilege to go and come when they please, to make contracts and enforce contracts, ... I shall introduce a bill and urge its passage through Congress that will secure to those men every one of these rights: they would not be freemen without them. It is idle to say that a man is free who cannot go and come at his pleasure, who cannot buy and sell, who cannot enforce his rights. ${ }^{115}$

Reconstruction principles simply because the elimination was universally applied. (It should be noted that Professor McConnell, in the article discussed above, also seems to take the view that the 1866 Act did protect the rights of contract, property, etc. See McConnell, supra, at 999.) It should be clear that by emphasizing "white" rights as a baseline, I see this Act as expanding rights for non-whites and implementing natural rights, not limiting non-whites to a "lowest common denominator" of rights. On this latter point, see Patricia Allan Lucie, White Rights as a Model for Blacks: Or-Who's Afraid of the Privileges or Immunities Clause?, 38 SYR. L. REV. 859 (1987).

${ }^{114}$ ERIC FONER, RECONSTRUCTION 288 (1988) (citing Alabama Union League Convention, Statement, Alabama StATE SeNTINEL, May 21, 1867) (emphasis in original).

115 CONG. GLOBE, 39th Cong, 1st Sess. 43 (1865). Trumbull echoed this position in his response to Johnson's veto of the Bill several months later. 
Tellingly, Trumbull referred to the listed freedoms as "privileges" and "rights." Senator Wilson took a similar view at that time, declaring that Congress needed to ensure that the freed slave would be assured

that he can go where he pleases; work when and for whom he pleases; that he can sue and be sued; that he can lease and buy and sell and own property, real and personal; that he can go into the schools and educate himself and his children; that the rights and guarantees of the good old common law are his, and that he walks the earth, proud and erect in the conscious dignity of a free man ...."116

Such statements seem more consistent with viewing the Civil Rights Act as securing already established natural rights than as establishing a mere equality that would permit the equal denial of the rights described as essential to freedom. It is also consistent with the Republican view that these rights were fundamental to freedom and that the Thirteenth Amendment, by securing freedom for former slaves, enabled Congress to pass the Civil Rights Act. To read the Act as a guaranty of equality without any such baseline would be to ignore the basic ideals of freedom embodied by the Thirteenth Amendment. ${ }^{117}$

The natural rights reading of the Civil Rights Act, like that same reading of the Fourteenth Amendment, must confront the problem of the variety of laws and rights as applied to whites (let alone to other races) existing from state to state in 1866 . If the right to buy and sell property is a natural right, what basis is there for differences in the rules and procedures governing the rights? The response to this problem is that natural

${ }^{116} I d$. at 111 . See also id. at 91 (Sen. Sumner discussing and comparing Russian emancipation of serfs); Lea S. VanderVelde, The Labor Vision of the Thirteenth Amendment, 138 U. PA. L. REV. 437, 476 (1989).

117 See, e.g., Hyman \& Wiecek, supra note 97, at 301 ("The right Americans-white Americans, at least-enjoyed the opportunity to enter into almost limitless civil relationships, and to gain or lose from these involvements was considered a precious right. This right underlay what Republicans meant by free labor."). On ideals of freedom and the drafters of the Thirteenth Amendment, see generally VanderVelde, supra note 116. For interesting recent explorations of the Thirteenth Amendment as a source for constitutional law before the revitalization of the Fourteenth Amendment in the 1950s, see Risa L. Goluboff, The Thirteenth Amendment and the Lost Origins of Civil Rights, 50 DUKE L.J. 1609 (2001); James Gray Pope, The Thirteenth Amendment Versus the Commerce Clause: Labor and the Shaping of American Constitutional Law, 1921-1957, 102 COLUM. L. REV. 1 (2002). 
rights never exist without particularization. Such particularization would necessarily differ in various jurisdictions, but so long as the differences were ones of procedure and mechanics, and not an outright denial of the right, the differences were permissible. William Nelson argues that Republicans who advocated a fundamental rights theory of the Fourteenth Amendment took a similar position. For example, Nelson cites Senator Edmunds who, when discussing the Fourteenth Amendment during the debates over the Fifteenth, stated that "[e]very lawyer knows ... that it is one thing to have a right which is absolute and inalienable, and it is another thing for the body of the community to regulate ... the exercise of that right." 118 Ultimately, the argument that the effectuation of rights may differ across jurisdictions is not itself sufficient to counter the evidence that many framers believed that fundamental rights exist and were encompassed by the Civil Rights Act or the Fourteenth Amendment.

My point here is not so much to establish that a natural rights reading is superior, but to demonstrate that such a reading - which Justices Bradley and Field pressed in Slaughter-House - had significant support and was within the range of understandings of the drafters and their contemporaries. By adopting Miller's reading of the Amendment, the revisionists adopt a misreading of the framers' intent that improperly converts a complex and ambiguous record into a simple declaration of equality and an almost mechanical incorporation of the Bill of Rights. As Professor Nelson has so aptly written, "[o]nly one historical conclusion can therefore be drawn: namely, that Congress and the state legislatures never specified whether section one [of the Fourteenth Amendment] was intended to be simply an equality provision or a provision protecting absolute rights as well."119

The Civil Rights Act of 1866 also exposes the second omission of Slaughter-House revisionism: the scope of congressional powers under Section Five of the Fourteenth Amendment. The Act not only addressed equality of fundamental rights, it also asserted congressional power to

118 William E. Nelson, The Fourteenth Amendment: From Political PrinCIPLE TO JudiCIAL DOCTRINE 120 (1988) (quoting CONG. GLOBE, 40th Cong., 3d Sess. 1003 (1869)). Nelson seems agnostic on the question of whether such an argument justifies anything beyond a legal requirement of equality; he does observe that it could have greater force in supporting the use of congressional powers under Section Five. Id. at 121-24. It is important to note that this argument in favor of local variation of rules was also used to justify the exclusion of women from the fundamental rights protections of the Amendment. See id. at 119-20 (discussing speech of John Bingham, CONG. GLOBE, 39th Cong., 1st Sess. 1089 (1865)).

${ }^{119}$ Id. at 123 . 
legislate on issues of national citizenship. In debates over the Act, Representative Wilson argued in favor of congressional protection of fundamental rights (security, liberty, and property): "Whatever these great fundamental rights are, [Congress] must be invested with the power to legislate for their protection or our Constitution fails in the first and most important office of government." ${ }^{120}$ Senator Sherman had earlier asserted that the rights eventually embodied in the Civil Rights Bill were essential to liberty under the Thirteenth Amendment, and that the Amendment was both "a guarantee of liberty to every inhabitant of the United States," and "an express grant of power to Congress to secure this liberty."121 President Johnson, in vetoing the Bill, argued that:

In all our history, in all our experience as a people living under Federal and State law, no such system as that contemplated by the details of this bill has ever before been proposed or adopted. They establish for the security of the colored race, safeguards which go infinitely beyond any that the General Government has ever provided for the white race. In fact, the distinction of race and color is, by the bill, made to operate in favor of the colored and against the white race. They interfere with the municipal legislation of the States, with the relations existing exclusively between a state and its citizens, or between inhabitants of the same State-an absorption and assumption of power by the General Government which, if acquiesced in, must sap and destroy our federative system of limited power, and break down the barriers which preserve the rights of the States. It is another step, or rather stride, toward centralization and the concentration of all legislative power in the national Government. ${ }^{122}$

The battle lines were set. Proponents of the Bill argued that Congress had the power to legislate over fundamental rights, at least to the extent of enforcing equality of those rights, while opponents argued that such fundamental rights were the exclusive province of the States, even on the question of equality. Indeed, the subsequent debate over the ratification of the Fourteenth Amendment, the question of congressional power-

${ }^{120}$ CONG. GLOBE, 39th Cong., 1st Sess. 1118 (1865). Senator Trumbull also asserted that the second clause of the Thirteenth Amendment was designed to enable Congress to secure the rights of freedom (contract, property, etc.) for the freed slaves. See id. at 43.

${ }^{121} I d$. at 41.

${ }^{122}$ CONG. GLOBE, 39th Cong., 1st Sess. 1681 (1866) (message of President Johnson). 
especially congressional power over the topics contained in Section One-raised some of the strongest concerns for southern whites who rejected the Amendment. ${ }^{123}$ When southern white governors proposed an alternative Fourteenth Amendment they adopted much of the substantive language of Section One of the amendment being considered for ratification, but omitted any congressional enforcement power, indicating a fundamental concern with the enforcement of Section One and not with its general principles (which the governors presumably believed they and their legislators could implement as they saw fit). ${ }^{124}$

${ }^{123}$ Arkansas's legislature rejected the Fourteenth Amendment. It was Arkansas's position that "the great and enormous power sought to be conferred on Congress by the amendment, by giving to that body authority to enforce by appropriate legislation the provisions of the first article of said amendment, would, in effect, take from the States all control over their local and domestic concerns, and virtually abolish to States." See Arkansas Legislature Resolution of Dec. 10, 1866, reprinted in 1 WALTER L. FLEMING, DOCUMENTARY HISTORY OF RECONSTRuCtion: Political, Military, Social, Religious, EduCational and INDUSTRIAL, 1865-1906, at 236-37 (1966). See also JAMES E. BOND, No EASY WALK TO FREEDOM: RECONSTRUCTION AND THE RATIFICATION OF THE FOURTEENTH AMENDMENT 236-37 (1997) (opposition of white Georgians to congressional powers).

${ }^{124}$ Southern Governors' Proposal for Fourteenth Amendment, reprinted in FLEMING, supra note 123, at 238. The southern governors' proposed substitute for Section One was:

Section 3. All persons born or naturalized in the United States, and subject to the jurisdiction thereof, are citizens of the United States, and of the States in which they reside, and the Citizens of each State shall be entitled to all the privileges and immunities of citizens of the several States. No State shall deprive any person of life, liberty, or property without due process of law, nor deny to any person within its jurisdiction the equal protection of the laws.

Id. at 240. This proposal parroted much of the actual Fourteenth Amendment, including the Citizenship Clause. Interestingly, it substituted a version of the Privileges and Immunities Clause of Article IV (itself rewritten to substitute "citizens of the several States" for "citizens in the several States") for the Privileges or Immunities Clause of the Fourteenth Amendment, indicating, perhaps, some fear that the Fourteenth Amendment version went farther in asserting national, as opposed to state-based, privileges and immunities. The change in the Article IV language was the same rewriting employed by Justice Miller in Slaughter-House and, in Miller's case, arguably was intended to avoid any implication of general, or national, citizenship privileges. See TRIBE, supra note 24, $\S 15-2$; Aynes, Constricting the Law of Freedom, supra note 24, at 636 . Indeed, as Dean Aynes has shown, Miller apparently supported the Southern, Johnsonian 
The congressional responses to Johnson's veto of the Civil Rights Bill are also instructive, since they reflect the Congress' understanding of the basis of their power when they took the (at that time) extraordinary step of overriding the veto. Senator Trumbull responded to Johnson's veto message with an argument common among Reconstruction Republicans: no state ever has the right to deny civil rights to people on the basis of color, and federal legislation that protects such rights does not interfere with the legitimate exercise of state sovereignty. ${ }^{125} \mathrm{He}$ also argued that the Thirteenth Amendment's enforcement provision granted Congress the power "to do whatever is necessary to protect the freedman in his liberty[.]"126 Senator Stewart repeated this argument based on the Thirteenth Amendment, and observed that while he hoped the States would take care of such essential matters on their own, Congress unquestionably had the power to act as well. ${ }^{127}$ While these statements indicate a range of understandings about the powers of Congress, from protecting equal treatment in basic rights to protecting liberty, broadly construed, they also demonstrate that the Congress, which drafted the Fourteenth Amendment, understood itself to possess power over the stuff of citizenship, and the power to explore what that stuff would be. ${ }^{128}$

That this "stuff" of citizenship might well mean more than mere equality and the Bill of Rights becomes evident through the even broader context of congressional actions in the first half of 1866 . The Civil Rights Act was not the only use of congressional power to promote national

alternative that de-fanged the Amendment. See Aynes, Constricting the Law of Freedom, supra note 24, at 660 n. 228 .

${ }^{125}$ See CONG. GLOBE, 39th Cong., 1st Sess. 1761 (1866) (statement of Sen. Trumbull).

${ }^{126} I d$. at 1759 . Trumbull's statement responding to President Johnson echoed his position just prior to passage of the Thirteenth Amendment that the Amendment gave Congress power to secure basic civil rights: "These [freedom of movement, freedom to buy and sell, freedom of contract] are rights which the first clause of the constitutional amendment meant to secure to all; and to prevent the very cavil which the Senator from Delaware suggests today, that Congress would not have power to secure them, the second section of the amendment was added." Id. at 43 .

${ }^{127} I d$. at 1785 (1866) (statement of Sen. Stewart). See also id. at 1835 (1866) (statement of Rep. Lawrence) ("The Constitution declares these civil rights to be inherent in every citizen, and Congress has power to enforce the declaration.").

${ }^{128}$ On the importance to the Reconstruction Era of the concept of citizenship generally and the Citizenship Clause in particular, see generally Jack M. Balkin \& Sanford Levinson, Understanding the Constitutional Revolution, 87 VA. L. REV. 1045, 1094-1102 (2001); Fox, supra note 24, at 489-545; Zietlow, supra note 6. 
citizenship at the time Congress drafted the Fourteenth Amendment. Congress also enacted legislation further defining and supporting the Freedmen's Bureau. Indeed, the Civil Rights Bill was originally part and parcel of the Freedmen's Bureau Bill. ${ }^{129}$ The Bureau had been established in 1865 to assist newly freed slaves and war refugees. The first version of the Reauthorization Act, which passed in 1866, demonstrated Congress' further support for what was essentially poor relief, health, and education programs for a significant population in the South, primarily recently freed African-Americans. ${ }^{130}$ Johnson vetoed this legislation (shortly before his veto of the Civil Rights Bill) on the grounds that it usurped states' exclusive powers and favored a particular class (blacks). ${ }^{131} \mathrm{John}-$ son's objection to the usurpation of state powers was probably on stronger ground with regard to the Freedmen's Bureau than the Civil Rights Bill, since the Bureau acted directly on citizens in areas traditionally reserved to state and local governments (poor relief, health, education), rather than simply requiring the states to enforce equality. Nonetheless, Congress reconfigured the Act and overrode another veto in order to continue the activities of the Bureau. It did so with an explicit connection of this direct federal assistance program to the concept of national citizenship. ${ }^{132}$

The Slaughter-House revisionists do not address the significance of Congress' support for the Bureau as a way of fully understanding the Citizenship and Privileges or Immunities Clauses of the Fourteenth Amendment, yet it is important evidence that Congress had already begun enforcing its own concepts of citizenship at the time it was drafting and

${ }^{129}$ CURTIS, No State Shall ABRIDGE, supra note 24, at 57. Akhil Amar has aptly characterized them as siblings. AMAR, THE BILL OF RIGHTS, supra note 24, at 260 .

${ }^{130}$ See EDWARD MCPHERSON, THE POLTICAL HISTORY OF THE UNITED STATES OF AMERICA DURING THE PERIOD OF RECONSTRUCTION 72 (1871) (reprinting the Freedmen's Bill of March 2, 1866, which was vetoed and not re-enacted).

${ }^{131} 8$ A COMPILATION OF THE MESSAGES AND PAPERS OF THE PRESIDENTS 3596 (John D. Richardson ed., 1897).

${ }^{132}$ Civil Rights Act, 14 Stat. 173, 174 (1868) (purpose of the act was to enable recipients of aid "to become self-supporting citizens of the United States," and help them in the freedom guaranteed by the Thirteenth Amendment). On the Freedmen's Bureau, see generally FONER, supra note 114, at 68-70, 142-70. For a collection of the scholarship on the Bureau, see THE FREEDMEN'S BUREAU AND BLACK FREEDOM (Donald G. Nieman ed., 1994), including the reprint of John and La Wanda Cox's 1953 article General O.0. Howard and the 'Misrepresented Bureau' at page 105. See also Fox, supra note 24, at 523-36. 
proposing the Fourteenth Amendment. ${ }^{133}$ The Bureau and its supporting Act can, I believe, help us understand the Fourteenth Amendment in two ways.

First, it further shows that the framers of the Fourteenth Amendment were willing to employ congressional enforcement powers to enter spheres "traditionally" reserved to the states. As was true with the Civil Rights Act, members of Congress understood the Thirteenth Amendment as granting the power to create and support the Freedmen's Bureau and its activities. ${ }^{134}$ The Enforcement Clause of the Thirteenth Amendment was seen as empowering Congress to maintain an administrative apparatus to provide subsistence and enable freedom for African Americans.

While the Freedmen's Bureau Act does demonstrate a congressional willingness to act in areas usually within the exclusive powers of the states, in some respects it did not go so far as the Civil Rights Act. The Civil Rights Act applied by its terms to all states and without any time limitation. The Freedmen's Bureau Act contained significant limits on its jurisdiction, in particular the Bureau was expressly restricted to acting in former Confederate states and only for a limited period. ${ }^{135}$ For this reason some congressmen, including John Bingham, did not view the Bureau Act with the same concerns for over-reaching congressional powers as they did the Civil Rights Act. ${ }^{136}$ On the other hand, President Johnson, in his veto of the Act, was greatly concerned that it interfered with the exclusive powers of the states over matters of poor relief, education, and other areas. ${ }^{137}$ For these reasons, the Bureau Act is more revealing for the types of provisions seen as essential to national citizenship than for a clear statement about congressional powers under the Fourteenth Amendment.

Second, the Bureau was seen as helping to bring people into freedom and citizenship, and the objects of its activities were the essentials of

${ }^{133}$ A few scholars have explored the meanings the Freedmen's Bureau lends to the Fourteenth Amendment. See, e.g., AMAR, THE BLL OF RIGHTS, supra note 24, at 260-62 (Freedmen's Bureau Act as evidence of incorporation of individual rights version of Second Amendment); Eric Schnapper, Affirmative Action and the Legislative History of the Fourteenth Amendment, 71 VA. L. REV. 753 (1985).

${ }^{134}$ See CONG. GLOBE, 39th Cong., 1st Sess. 43, 77, 322 (1865) (statement of Sen. Trumbull); id. at 2773 (statement of Rep. Eliot). The Bureau had originally been based in the War Powers, but ratification of the Thirteenth Amendment provided additional footing for their congressional action.

${ }^{135}$ Freedmen's Bureau Act $\S 1,13$ Stat. 507, § 1, 14 Stat. 173 (1866).

${ }^{136}$ CONG. GLOBE, 39th Cong, 1st Sess. 1291-92 (1866) (Rep. Bingham). See also Aynes, On Misreading John Bingham, supra note 93, at 72-73.

1378 A COMPILATION OF THE MESSAGES AND PAPERS OF THE PRESIDENTS, supra note 131 , at 3596 . 
citizenship. ${ }^{138}$ Ideas of freedom were intricately entwined with ideas of citizenship, since American citizens were seen as a free people. Poor relief was important because severe destitution prevented people from being free citizens capable of labor and self-support. ${ }^{139}$ Medical services were also central to the congressional vision of the relief of destitution. ${ }^{140}$ Education was central to enable people to be participating citizens, from the polls to the labor market. ${ }^{141}$ And access to the courts was central for citizens to be able to enforce those citizenship rights deemed fundamental and identified by both the Freedmen's Bureau Act and the Civil Rights Act. ${ }^{142}$ None of these areas contained in the Bill of Rights, yet the Reconstruction Congress deemed them important enough to establish unprecedented federal involvement through the Bureau in spheres traditionally reserved to the state. At the very least, the congressional support for the Bureau indicates a recognition within Congress that some basic level of health, education, and welfare was necessary for the full exercise of the privileges and immunities of citizenship.

When looked at in light of the Civil Rights Act and the Freedmen's Bureau, it becomes much more difficult to limit the constitutionalization of United States citizenship and its privileges and immunities or to restrict congressional powers to enforce those privileges and immunities to the Bill of Rights alone. The framers of the Amendment were exploring a variety of means of creating citizenship and preserving privileges and immunities. ${ }^{143}$ To restrict our own view of the Privileges or Immunities

${ }^{138}$ I have explored this elsewhere. See Fox, supra note 24, at 523-36.

${ }^{139}$ See id. at 529-30 (Senator Trumbull's views on poverty relief and the Freedmen's Bureau); id. at 542-45 (Republican's views on destitution relief more broadly).

${ }^{140}$ See, e.g., Freedmen's Bureau Act, $\S 5,14$ Stat. 173, 174 (1868) (the portion of the Act reauthorizing the Bureau).

${ }^{141}$ On education and the Freedmen's Bureau, see Paul A. Cimbala, Making Good Yankees: The Freedmen's Bureau and Education in Reconstruction Georgia, 1865-1870, in THE FREEDMEN's BUREAU AND BLACK FREEDOM at 57 (Donald G. Nieman ed., 1994), reprinting 29 ATLANTA HISTORICAL J. 5 (1985). See generally JACQUELINE JONES, SOLDIERS OF LIGHT AND LOVE: NORTHERN TEACHERS AND GEORGIA BLACKS 1865-1873 (1980). The 1866 reauthorization of the Bureau expressly supported educational activities. See 14 Stat. 173, 176 (§§ 12-13).

${ }^{142}$ See, e.g., 14 Stat. $173,176(\$ 14)$.

${ }^{143}$ One could add to this the Republican Party's more limited actions to promote education through the 1862 Morrill Act and its 1866 extension to the Southern states, and to broaden property ownership through the land distribution policies of the Homestead Acts of 1862 and 1867. On these matters, see ROGERS SMITH, CIVIL IDEALS 277-78, 320-21 (1997); FONER, supra note 114, at 246. 
Clause to the reinterpreted version of Slaughter-House would be to ignore both historical evidence and future potential.

\section{Reading the Fourteenth Amendment}

If the Slaughter-House revisionists are indeed taking us down an unnecessary path that obscures other possibilities, what are those possibilities? If their Bill-of-Rights-only approach to the Privileges or Immunities Clause is not the best way to read the Clause, then what is? Do we necessarily adopt the no-holds-barred, freedom-of-contract/free labor perspective of the dissents in Slaughter-House, or is there some middle ground reasonably consistent with the Fourteenth Amendment and the background of its adoption?

Michael Kent Curtis has recently explored this question. Professor Curtis has performed much of the scholarly hard labor over the past two decades to show that the Privileges or Immunities Clause was meant to incorporate the Bill of Rights; he has continued to demonstrate this in two recent articles on the Clause. ${ }^{144}$ Although Curtis does not himself adopt the revisionist view of Slaughter-House, his efforts to demonstrate an intent to incorporate the Bill of Rights through the Privileges or Immunities Clause have an outcome similar to that of the Slaughter-House revisionists. ${ }^{145}$ His recent work, however, also addresses the question left open by the revisionists: whether the Clause contains, or can contain, something beyond incorporation.

In his 1996 work, Curtis explores the debates over the Civil Rights Act to determine what the intent might have been, both for that act and for the related Section One of the Fourteenth Amendment. ${ }^{146} \mathrm{He}$ concludes that while the evidence supporting incorporation is fairly strong, the evidence of whether protections beyond the Bill of Rights were included, or how such federal rights and privileges would affect federalism, is far less clear. ${ }^{147}$ Indeed, Curtis' analysis indicates that some of the framers seem to

${ }^{144}$ See CURTIS, No STATE SHALL ABRIDGE, supra note 24; Curtis, Resurrecting the Privileges, supra note 68; Michael Kent Curtis, Historical Linguistics, Inkblots, and Life After Death: The Privileges or Immunities of Citizens of the United States, 78 N.C.L. REV. 1071 (2000) [hereinafter Curtis, Historical Linguistics]. Curtis also addresses some of these issues in his recent book on the history of free speech protection. See generally CURTIS, FREE SPEECH, supra note 112, at 357-83.

${ }^{145}$ Curtis seems to have been partially persuaded by Wildenthal's piece. See Curtis, Historical Linguistics, supra note 144, at 1074 n.15.

${ }^{146}$ Curtis, Resurrecting the Privileges, supra note 68, at 36.

${ }^{147}$ Id. at 37. 
have wanted contradictory goals: both the federal power to protect life, liberty and property, and a continuation of state sovereignty over basic legal rights such as property and contracts-a contradiction that Curtis perceptively notes was understandable given the momentous and difficult period of war and reconstruction. ${ }^{148}$ Ultimately, Curtis concludes that, other than incorporation of the Bill of Rights, the main thrust of the Privileges or Immunities Clause was to secure equality of treatment with respect to fundamental rights and privileges. Like the Slaughter-House revisionists, Curtis sees his interpretation as respecting the framers' desire to balance federal protection of rights with their simultaneous desire to preserve state sovereignty. ${ }^{149}$

Curtis is particularly weary of efforts to convert the Clause into a broadsword for protection of economic rights a la the Lochner-Era. ${ }^{150}$ Curtis seems most concerned that the Court not assert the power to employ a rationality review to overturn state laws. ${ }^{151}$ This is arguably exactly what the dissenters in Slaughter-House wanted to do, and some scholars view those dissents as a foreshadowing of the Lochner demons. ${ }^{152}$

While Curtis senses an appropriate caution with the project of reinvigorating the judicial theories of the Slaughter-House dissents, his concerns do not properly account for the legislative opposition to the Court's interpretation. This focus on judicial interpretation and powers tends to unnecessarily circumscribe the Privileges or Immunities Clause and the Fourteenth Amendment. According to this view, limiting the meaning of the clause to textually defined rights prevents a judicial usurpation of constitutional authority that will bring back the ghosts of

${ }^{148}$ Id. at $41-43$.

${ }^{149}$ See, e.g., id. at $57,68,88-89$. This analysis of Curtis admittedly takes him a bit out of context. Curtis has been responding primarily to an argument that the Privileges or Immunities Clause only establishes equality: The main proponents of this view include John Harrison, Reconstructing the Privileges or Immunities Clause, 101 YALE L.J. 1358 (1992), and to a lesser degree, NELSON, supra note 118. Curtis argues that the Clause does more, and that this something more clearly includes incorporation of the Bill of Rights. He does not grapple directly with the contention that the something more may also include fundamental rights beyond establishing equality in treatment with respect to those rights.

${ }^{150}$ See Curtis, Resurrecting the Privileges, supra note 68, at 95-106.

151 See Curtis, Historical Linguistics, supra note 144, at 1150.

152 See, e.g., KERMIT L. HALl ET AL., AMERICAN LEgal HiSTORY: CASES AND MATERIALS at 370 (2d ed. 1996); Curtis, Resurrecting the Privileges, supra note 68, at 85; Newsom, supra note 3, at 665; Wildenthal, How I Learned to Stop Worrying, supra note 4, at 246. 
Lochner and perhaps threaten representative democracy itself. If the Court can indiscriminately fashion reasons for overturning state laws, the greatest political power will reside with the unelected judiciary. ${ }^{153}$ This is true, however, only if we allow that the Court is the sole actor. If only the Court is allowed to declare what the Privileges or Immunities vessel contains, then these criticisms are forceful. If, on the other hand, Congress has some leeway in declaring and particularizing privileges and immunities, the concern that the Clause will result in undemocratic political action evaporates (although the concern for unbridled federal powers comes to the fore) ${ }^{154}$ The focus on judicial interpretive power distracts attention from and implicitly devalues Congressional interpretive powers, which seems odd in light of the affirmative grant of congressional power in Section Five of the Amendment. ${ }^{155}$ Ultimately, such a failure to credit the potential of Section Five deprives the Fourteenth Amendment of its fundamental

${ }^{153}$ See, e.g., Curtis, Resurrecting the Privileges, supra note 68, at 101.

${ }^{154}$ Justice Breyer recently made a similar point in critiquing the Court's close scrutiny of congressional action under Section Five of the Fourteenth Amendment. See Board of Trustees v. Garrett, 531 U.S. 356, 383 (2001) (Breyer, J., dissenting) (" 'Limitations stemming from the nature of the judicial process ... have no application to Congress.' Oregon v. Mitchell, 400 U.S. 112, 248 (1970) (Brennan, White, and Marshall JJ., concurring in part and dissenting in part.)").

${ }^{155}$ At one point Curtis asserts that Republicans recognized the potential breadth of Section Five's enforcement power and "feared that an excessively broad definition of the interests protected by Section 1 would grant Congress equally broad powers to preempt state legislation." Curtis, Resurrecting the Privileges, supra note 68, at 101-02. The implication here is that the framers preferred a narrow definition of the Privileges or Immunities Clause to avoid excessive federal powers. The problem with this view is that the framers also wanted to empower themselves to act, as they had with the Civil Rights Act of 1866. Curtis, however, also cites favorably the Enforcement Act of 1871 as a reasonable interpretation of the state action aspect of the Fourteenth Amendment, and as an alternative to the Court's interpretation in United States v. Cruikshank. Id. at 89-90. See also CURTIS, FREE SPEECH, supra note 112, at 381-83. This argument seems to support the idea that Congress was interpreting (interpretation being necessary to particularization of broad rights) the Clause and since the interpretation was reasonable it should be granted some respect (I purposely avoid the legally loaded term "deference," although in common usage that's what it is). See McConnell, Institutions and Interpretation, supra note 6, at 184-94. For an argument that the framers did not intend the state action language of Section One to limit congressional enforcement of the Amendment against private actors under Section Five, see generally Laurent B. Frantz, Congressional Power to Enforce the Fourteenth Amendment Against Private Acts, 73 YALE L.J. 1353 (1964). 
revolutionary character. As one scholar of the ratification of the Amendment recently stated, "[t]he Fourteenth Amendment was revolutionary, not because it redefined privileges and immunities to include the guarantees of the Bill of Rights, but because it gave Congress the power to define and therefore expand the Privileges and Immunities of citizenship ...."156

Professor Curtis has also provided excellent historical analysis of the original meaning of the Privileges or Immunities Clause. Not only does Curtis investigate a broad range of sources to try to determine the meaning of the Clause, he also recognizes that original meaning is but one of several sources of constitutional interpretation, albeit one he gives much weight. For Curtis, it is possible to determine with reasonable confidence that the terms "privileges" and "immunities," used in conjunction with "national citizenship," were understood to encompass the Bill of Rights. He provides extensive support for this position. Curtis appears reluctant to posit any meanings for the phrases beyond the Bill of Rights, however, likely due to lack of support or conflicts in the evidence. ${ }^{157}$

Despite the strengths of Curtis' analysis, there are important criticisms of this approach. First, assuming one is willing to explore the originalist methodology used by Curtis, ${ }^{158}$ it is possible that the vague words "privi-

${ }^{156}$ BOND, supra note 123 , at 255.

${ }^{157}$ See generally Curtis, Historical Linguistics, supra note 144. See also Curtis, Resurrecting the Privileges, supra note 68, at 24-25 ("The Fourteenth Amendment did not create new privileges. It created a.new method of protecting old and inadequately secured privileges [such as those in the First Amendment]."). $C f$. Aynes, Constricting the Law of Freedom, supra note 24, at $628 \mathrm{n.4}$ (framers did not intend to create new substantive rights).

${ }^{158}$ A note on originalism may be appropriate. The critique in the text operates mostly within the context of an originalist or historical perspective. One might well criticize the very project of applying originalism or any historical analysis to the Fourteenth Amendment. It may be that we should not be bound by the understanding of the framers and of Americans generally regarding what were national privileges and immunities or congressional powers in 1866-68. This raises theoretical issues that go beyond the scope of this paper. My own developing view is that historical interpretations and investigations are relevant for us to understand constitutional text and issues and to enrich our own interpretations and understandings of the text, but that these historical studies are only one of many (and not especially privileged) tools for us as modern interpreters. The problem of conforming original understandings to modern interpretations is particularly evident with the Fourteenth Amendment because it is fairly clear from the historical record (at least as clear as the incorporation of the Bill of Rights through the Privileges or Immunities Clause) that women were not to be included in the protections of the Fourteenth Amendment, and especially not the Privileges or 
leges" and "immunities" were understood to be developed over time, and, given Section Five's enforcement powers, that the development would be at least in part by the Congress. That is, the original meaning of Section Five was to allow Congress to supply future meaning to "Privileges or Immunities." This is perhaps more likely in an era where Congress repeatedly acted to protect the rights of American citizens within the states. One of the purposes behind using broad language such as "Privileges or Immunities," and including a power of congressional enforcement would, under this analysis, be to permit Congress to develop privileges and immunities through applications to particular events and circumstances, perhaps unforeseeable to the drafters. ${ }^{159}$ The framers were living through

Immunities Clause. See Ward Farnsworth, Women Under Reconstruction: The Congressional Understanding, 94 Nw. U. L. REV. 1229 (2000); Maltz, The Constitution and Nonracial Discrimination, supra note 113, at 266-82. Yet, few people today would contend that such original meanings or intent should control our modern interpretation of the Amendment. It seems to me that the best explanation of this "exception" to originalism is to admit that historical explorations are always being checked against modem sensibilities, cultural changes, and moral advances. $C f$. RICHARDS, supra note 67, at 230-32 (discussing how we can and should weave together text, history, and political theory in interpreting the Privileges or Immunities Clause (and the Constitution generally)). As I mentioned above, I think it is plausible that the framers of the Amendment "intended" to permit these changes (and so might have accepted the fact that women would be included within protections of the Clause in the late Twentieth Century even when they rejected it in their own time); even if the framers did not so intend, however, such changes are essential to any understanding of textual interpretation over time in a constitutional context. Thus, I view our exploration of the historical background of the Amendment as important both in understanding the historical perspective and context of the Amendment and Slaughter-House Cases, and in reconceiving our current interpretation of the two; I do not believe, however, that we are bound to understandings of the framing period. For a similar statement of an historical approach, see Curtis, Resurrecting the Privileges, supra note 68, at 4 5.

${ }^{159}$ The comments of Representative Dawes in 1871 during debates over the Enforcement Act suggest such a theory:

"I talk of nothing but constitutional guarantees; I do not claim myself to be able to comprehend their full measure and scope. As long as the American citizen shall live under this flag and expanding his pursuits in his honest endeavors, so long his constitutional guarantees will expand and grow with him, and be equal to and cover every lawful enterprise and undertaking of his within the limits of this Republic; and no man can define them upon paper until they come up."

CONG. GloBE, 42d Cong., 1st Sess. 476 (1871). 
a period of rapid evolution in political and social views. The radical ideas of small groups of abolitionists in the 1830s and 1840s had become the dominant discourse in the halls of Congress by $1866 .{ }^{160}$ The right of suffrage for black males, which would have been inconceivable in 1860 , and was deemed impossible in 1866, became reality in 1870 . As Senator Stewart said in explaining why he had moved during the five months of congressional debate from opposing suffrage to supporting it: "The world moves, and those who do not perceive it are dead to the living issues of the day. I have always advocated the necessity of taking the world as we find it, and following the logic of events. The development of new facts is constantly exploding old theories." ${ }^{161}$ To fix ideas as essential as the rights and privileges of citizenship with particularity would have been to deny the recent history of the country and the possibilities of future generations of Americans and their congressional representatives. By employing broad language (and notably not employing the particularized language of the Civil Rights Act) the framers may well have wanted to allow for congressional and social flexibility, even if that flexibility was not foreseeable to them. ${ }^{162}$

Second, even if one does not grant that the Enforcement Clause gives Congress power to define the particulars of the Privileges or Immunities Clause, there is another consideration in favor of congressional powers to define national privileges: the term itself had been understood to include legislatively created rights and privileges. Curtis' analysis essentially

${ }^{160}$ See generally TENBROEK, supra note 92; CURTIS, FREE SPEECH, supra note 112. See also Kaczorowski, To Begin the Nation Anew, supra note 92, at 49 (the movement of abolitionist theories on civil rights to the mainstream of Republican thought "reveals the extent to which the Civil War radicalized American politics").

${ }^{161}$ CONG. GLOBE, 39th Cong., 1st Sess. at 2799 (1866). For Stewart's statements from January 1866 against black suffrage and in favor of "Anglo-Saxon" rule, see $i d$. at 298. Representative Patterson also observed the changing of attitudes common at the time during the debates over the Thirteenth Amendment: "The English definition of justice and liberty in the twelfth century is not the definition of the nineteenth. Our interpretation of these terms in the future of our history will vary with education and local prejudices." CONG. GLOBE, 38th Cong., 2d Sess. 484 (1865).

${ }^{162}$ See Kaczorowski, Revolutionary Constitutionalism, supra note 82, at 92528. See also Alexander M. Bickel, The Original Understanding and the Segregation Decision, 69 HARV. L. REV. 1, 59-65 (1955); cf. William W. Van Alstyne, The Fourteenth Amendment, the "Right" to Vote, and the Understanding of the Thirtyninth Congress, 1965 SUP. CT. REV. 33, 77-78 (1965). 
restricts "privileges" to "natural" rights. ${ }^{163}$ This is particularly puzzling with respect to Curtis because he provides such a detailed examination of the historical understanding of the terms. ${ }^{164}$

Many privileges were granted or created by antebellum state legislatures. Statutorily granted privileges and immunities (and rights) were attached to particular statuses. Corporations had privileges granted them by legislative incorporation laws, ${ }^{165}$ colleges obtained educational privileges by statutory grants, ${ }^{166}$ inn and tavern keepers had privileges granted by licenses, ${ }^{167}$ and local governmental entities had township privileges (historically related to corporate privileges). ${ }^{168}$ Citizenship and residence were also statuses to which certain privileges attached. As Justice Shaw stated in the important fugitive slave case of Commonwealth $v$. Aves, "as a general rule, all persons coming within the limits of a state, become subject to all its municipal laws, civil and criminal, and entitled to the privileges which those laws confer ...."169 Here, Shaw appears to base this principle both on Article IV's Privileges and Immunities Clause and

${ }^{163}$ Curtis, Historical Linguistics, supra note 144, at 1132-38; Curtis, Resurrecting the Privileges, supra note 68, at 67-71.

${ }^{164}$ See generally Curtis, Historical Linguistics, supra note 144. It is understandable, however, when one recalls that Curtis' focus is on demonstrating that the Bill of Rights' guarantees were, at the very least, part of the understanding of "privileges" and "immunities," regardless of whatever else one might decide the terms included. Curtis recognizes that the term "privileges" and "immunities" had other meanings but does not explore them in detail. See, e.g., id. at 1101 ("When people [circa 1787] spoke of their invaluable privileges, it is not always clear whether they referred to a common heritage of the American people, merely to specific rights under state law, or to both"); id. at 1137 (some congressmen, such as Senator John Sherman, believed that the Privileges or Immunities Clause encompassed rights in addition to the Bill of Rights, including some common law rights).

${ }^{165}$ E.g., Anderson v. Brock, 3 Me. 243 (1825) (grants of privileges and immunities of a corporate nature to religious groups); Old C. \& F.R.R. Co. v. County of Plymouth, 80 Mass. 155 (1859) (statutory privileges and immunities for corporations).

${ }^{166}$ E.g., Dartmouth College v. Woodward, 17 U.S. (4 Wheat.) 518 (1819); Sage v. Dillard, 54 Ky. (15 B. Mon.) 340 (1854).

${ }^{167}$ E.g., Wason v. Severance, 2 N.H. 501, 502 (1822) (privilege of innkeeper to sell liquor).

${ }^{168}$ E.g., Eastman v. Meredith, 36 N.H. 284, 292-93 (1858) (discussing grant of privileges to towns and comparing them to corporate grants); Sewall v. Cargill, 15 Me. 414, 416 (1839).

${ }^{169}$ Commonwealth v. Aves, 35 Mass. 193 (1836). 
general principles of law. Whatever the source, the point remains that a state's laws grant privileges that attach to people present in the state by the fact of their presence: the granting of privileges is one of the things that statutes do. Indeed, the concept of granting privileges to citizens by state legislatures is essential to the Privileges and Immunities Clause of Article IV. ${ }^{170}$ If state legislatures were understood prior to the 1860 s to be capable of granting privileges, and if residence and citizenship were included in those statuses to which certain statutory privileges obtained, then the framers could have understood that the establishment of federal privileges and immunities had, as one of its purposes, the empowerment of the national legislature to grant privileges of national citizenship. ${ }^{171}$

The historic importance of legislative conferral of privileges and immunities also counsels in favor of seeing Congress as a significant interpreter of the Privileges or Immunities Clause. The legislature has a particular relationship with privileges and immunities, one arguably different from its relationship to due process and equal protection. The text

${ }^{170}$ U.S. CoNST. art. IV, $\S 2$, cl. 1 . The issue in antebellum law under Article IV was whether the particular privilege granted by a state statute or law was of a category that also required non-discrimination against the exercise of the privileges by out-of-staters. Justice Washington, in Corfield v. Coryell, 6 F. Cas. 546 (C.C.E.D. Pa. 1823) (3230), held that only "fundamental" privileges were included in this category.

${ }^{171}$ The Supreme Court, in 1855 , recognized that Congress possessed the power to create "privileges and immunities" for ships entering ports. See Pennsylvania v. Wheeling \& Belmont Bridge Co., 59 U.S. 421, 435 (1855). See also Rich, Privileges or Immunities: The Missing Link, supra note 6, at 244. Professor Rich goes too far, I think, in concluding that this case involved privileges and immunities as related to national citizenship; the case does, however, reveal a general understanding of the national legislative power to create privileges. See also Act of 1864, ch. 173, 13 Stat. 241 (congressional grants of privileges and immunities to revenue officers). On antebellum federal cases implicitly supporting a broader understanding of what constitutes privileges and immunities under Article IV, see Rich, Privileges or Immunities: The Missing Link, supra note 6, at 240-49. To the contrary of the position set forth above, Douglas Smith has argued that the Privileges or Immunities Clause was not intended to encompass "special" privileges such as those established by state incorporation laws, see Smith, The Privileges and Immunities Clause, supra note 92, at 902-04. The Clause was intended to cover a "closed set of privileges and immunities," see Smith, Natural Law, supra note 92, at 395. Despite Smith's excellent work in uncovering the origins of the Clause, I believe he takes insufficient account of Section Five of the Fourteenth Amendment as a source for development of the privileges of citizenship. 
of the Fourteenth Amendment, notably, does not distinguish the enforcement powers of Congress based on which specific language within the amendment Congress would be enforcing. Nonetheless, of all the terms in Section One, the Privileges or Immunities Clause seems the most apt for congressional development. It calls for affirmative grants of privileges based on determinations of what the community (national citizenship) believes to be essential to its own existence. Far from being an illegitimate assertion of congressional powers, expanded congressional powers to implement the Privileges or Immunities Clause would seem democratically more legitimate than judicial restraints on congressional powers that require a tight fit between congressional action and the unelected judiciary's determination of the privileges of citizenship. ${ }^{172}$

Critics might likely respond that even if these two types of privileges - fundamental and positive (or statutory)-existed in the 1860 s, the Privileges or Immunities Clause only addresses the fundamental privileges. This could be consistent with the framers' citations to Justice Washington's dicta in Corfield, where he emphasized that the Privileges and Immunities Clause of Article IV encompassed fundamental privileges, such as contract, liberty of movement, property, etc., and not mundane privileges, such as oystering. ${ }^{173}$ Thus, the framers arguably intended the Privileges or Immunities Clause to incorporate only the fundamental privileges, more akin to natural rights, and not to empower Congress to create new privileges.

Again, this is a reasonable reading of the text and context, but it is not the only reasonable reading. Pushed to its conclusion, the argument proves too much, because it would deny that Congress has any power to create national privileges, which it plainly does have through its enumerated powers in Article I. As Professor Rich has recently pointed out, Congress may well use its Article I powers to create privileges of national citizenship. ${ }^{174}$ Interestingly, Justice Miller seems to have alluded to this. His relatively restricted definition of the Clause in Slaughter-House included privileges that "owe their existence to the Federal government, its National character, its Constitution, or its laws." 175 None of the Slaughter-House revisionists explore the possible import of Miller's inclusion of Congress'

${ }^{172} \mathrm{Cf}$. McConnell, Institutions and Interpretation, supra note 6, at 156.

${ }^{173}$ Corfield v. Coryell, 6 F. Cas. 546, 552 (1823).

${ }^{174}$ Rich, Privileges or Immunities: The Missing Link, supra note 6, at 301.

175 The Slaughter-House Cases, 83 U.S. (16 Wall.) 36 (1872) (emphasis supplied). 
"laws" in this definition of privileges and immunities; at the very least it should mean those laws which are passed under the powers of Article I.

Professor Rich has also recently offered an alternative reading of the Clause that captures both the fundamental rights concept and the positive rights potential of congressionally granted rights and privileges. He argues that the antebellum understanding of "privileges" included both natural or fundamental rights and rights created by legislatures. ${ }^{176} \mathrm{He}$ contends that this "two-tiered" structure of the term can be adapted to the national political structure so that congressional statutes can, in some instances, be deemed to grant national privileges. ${ }^{177}$ While I have some reservations about Rich's application of this insight, in particular with his unwillingness to see the Fourteenth Amendment as an independent source for Congress to create national privileges, ${ }^{178} \mathrm{it} \mathrm{seems} \mathrm{to} \mathrm{me} \mathrm{essential} \mathrm{to} \mathrm{consider} \mathrm{the} \mathrm{point}$ that "Privileges or Immunities" was understood to include congressionally created rights and privileges.

By concentrating on Slaughter-House and a revival of the Privileges or Immunities Clause as another route to incorporate the Bill of Rights, the revisionists overlook this important background to the drafting of the Fourteenth Amendment and the Citizenship and Privileges or Immunities Clauses. To a certain extent they are repeating Justice Miller's error in refusing to address the Civil Rights Act as background for the Privileges or Immunities Clause. Like Miller, they take the Clause partially out of context and drain it of the potential it had when drafted in $1866 .{ }^{179}$ The

${ }^{176}$ Rich, Privileges or Immunities: The Missing Link, supra note 6, at 256.

${ }^{177} I d$. at 301 .

${ }^{178}$ Id. at 257.

${ }^{179}$ Wildenthal addresses this point by asserting allegiance to textualist interpretive methodology. He views the Bill-of-Rights-only interpretation as more consistent with the text and would not look farther for definitions of privileges and immunities. Wildenthal, The Lost Compromise, supra note 4, at 1170-72. Newsom's position is more troubling. He argues that Justice Miller was a staunch advocate of original intent jurisprudence, Newsom, supra note 3, at 696, yet cannot adequately explain Miller's refusal to discuss the statements or activities of the Congress that drafted the Amendments at issue. The closest he comes is to argue as follows: first, that Miller had a general policy (not discussed in Slaughter-House but supported by Newsom's research) of following original intent; second, that the framers had an intent to incorporate the Bill of Rights but no intent to incorporate other rights such as those mentioned in Corfield; and, third, that Miller could therefore not have meant to exclude the Bill of Rights from the Privileges or Immunities Clause. Id. at 696-703. This is another example of Newsom's generous reading of Miller's opinion. As discussed above, I think Newsom is wrong about the second point. Moreover, it shows poor judicial and intellectual form consider- 
revisionists should be applauded for correcting many common mis-readings of Slaughter-House. But by re-reading Slaughter-House's reading of the 1860 s Amendments, the revisionists unfairly de-radicalize Reconstruction and under-read the Fourteenth Amendment. The better source for divining some potential meanings of the Privileges or Immunities Clause is not case law from the 1870 s, but the congressional and historical context of Reconstruction itself.

\section{RECONSTRUCTION AND THE \\ CONGRESSIONAL POWER OF INTERPRETIVE ENFORCEMENT}

I remain agnostic on the question of whether the Privileges or Immunities Clause was meant to (or should today be interpreted to) include natural rights beyond those listed in the Bill of Rights and Equal Protection and Due Process Clauses. There is significant evidence that several framers contemplated this, and, as mentioned above, this terrain has been wellmapped by others. The more significant problem for me, and the one frequently ignored by Slaughter-House revisionists and others who focus on the Privileges or Immunities Clause, is the possibility of congressional definition of specific privileges and immunities. ${ }^{180}$ Exploration of

ing that Justice Field explicitly took Miller to task for not discussing the Civil Rights Act and not addressing Field's (and counsel's) argument that the original intent ran against Miller's conclusions. Slaughter-House, 83 U.S. (16 Wall.) at 9192 (Field, J., dissenting). Palmer similarly errs. He defends Miller's refusal to address the Civil Rights Act by arguing that Miller, like some Republicans in Congress, probably considered the Act unconstitutional and therefore irrelevant. Palmer, supra note 4, at 756. The problem is that the Amendment was seen as enabling enactment of the Civil Rights Act, and that the Civil Rights Act was reenacted in 1870, well before the Slaughter-House opinion. Miller could legitimately have read the Act differently, but his failure to address it shows a refusal to engage in constructive discourse about the intent of the framers of the Amendment. If Newsom is correct that Miller valued original intent, such a refusal to engage in the originalist discourse more likely means that Miller felt he would lose the argument.

${ }^{180}$ William Rich provides an important recent exception to this trend of omission. Rich, Privileges or Immunities: The Missing Link, supra note 6. He argues that Congress retains the power to create privileges through its Article I powers. His focus then shifts to showing how the Fourteenth Amendment gives backbone to certain types of Article I legislation and should overcome objections to the legislation based on the Eleventh Amendment. See generally id. at 283-304; Rich, Taking "Privileges or Immunities" Seriously, supra note 6. Michael Kent Curtis has also explored post-1866 congressional actions, but with a predominant 
congressional actions during and after ratification of the Fourteenth Amendment are important for understanding how the Reconstruction generation and Congress understood the role of the national legislature under the Amendment. The Civil Rights Act of 1875 becomes especially important here because it was debated simultaneously with the Court's consideration of and decision in Slaughter-House; these debates reflect congressional understandings of the Amendment, its Privileges or Immunities . Clause, and the Court's reading (or misreading) of the Amendment. ${ }^{181}$

\section{A. Civil Rights Act of 1866 and the Principle of Interpretive Enforcement ${ }^{182}$}

The most obvious evidence that the Fourteenth Amendment's Enforcement Clause was intended to enable broad congressional actions and interpretations of Section Five comes from the Civil Rights Act of 1866. As discussed above, the Act serves as evidence of the possible meaning of the Privileges or Immunities Clause. This is because when drafting Section One the framers were thinking, inter alia, of the things they were protecting in the Civil Rights Act. They wanted the principles of the Act raised to constitutional, supermajoritarian status. ${ }^{183}$ The Civil Rights Act is a rich source for understanding the Fourteenth Amendment because

focus on the Bill of Rights and, to a lesser extent, state action. See CURTIS, No STATE SHALL ABRIDGE, supra note 24, at 154-70.

${ }^{181}$ My approach to using the post-1866 congressional actions to explore the meaning of and possibilities for the Fourteenth Amendment is somewhat similar to Professor McConnell's method in exploring originalism and segregated schools. See McConnell, Originalism, supra note 113. His analysis focuses on segregated schools, touching as necessary on broader questions. I concentrate on the broader issues of the possible meanings of the Privileges or Immunities Clause and the range of congressional powers. My choice to explore congressional actions has been influenced by McConnell's work as well as by the fine efforts of other scholars. See, e.g., Wildenthal, The Lost Compromise, supra note 4; Aynes, Constricting the Law of Freedom, supra note 24, at 679-81; Kaczorowski, To Begin the Nation Anew, supra note 92.

${ }^{182}$ On the concept of interpretive enforcement under Section Five, see generally McConnell, Institutions and Interpretation, supra note 6. Cf. Jack Wade Nowlin, The Constitutional Illegitimacy of Expansive Judicial Power: A Populist Structural Interpretive Analysis, 89 KY. L.J. 387, 447-48 (2000-2001).

${ }^{183}$ In fact, the Civil Rights Act had achieved supermajoritarian status in Congress because it was enacted with the two-thirds majority necessary to override the Johnson veto. 
it also tells us the possible meaning of Section Five, as several commentators have argued. ${ }^{184}$. The textual source for Section Five was Section Two of the Thirteenth Amendment. The interpretive position that the drafters took towards the Enforcement Clause of the Thirteenth Amendment strongly reveals their own ideas of what their powers were under Section Five. It also served as notice to the states asked to ratify the Amendment of just what powers they were establishing in Congress. ${ }^{185}$

By its language, the Thirteenth Amendment eliminates "slavery and involuntary servitude." It says nothing about the right to contract, rights to hold property, rights of access to courts, or citizenship. Yet Congress found the power to enact legislation guarantying these rights through its power to enforce the Amendment. To do this Congress had to assume the power to interpret the language of Section One to cover the topics encompassed by the Civil Rights Act. Thus Senator Trumbull argued that the Amendment gave Congress the power "to protect every person in the United States in all the rights of person and property belonging to a free citizen." 186 The interpretive argument was that the abolition of slavery meant the establishment of freedom, and the establishment of freedom meant the guaranty of the rights to sue, contract, hold property, etc. ${ }^{187}$ Congress was enforcing Section One because it understood the anti-slavery language of Section One broadly. One can argue about whether Congress' interpretation was right, but it is beyond doubt that Congress was interpreting the language of Section One. It would be odd indeed to think that, in structuring the Fourteenth Amendment parallel to the Thirteenth, Congress did not think Section Five of the Fourteenth granted it this power of interpretation.

It is also revealing to follow Congress' interpretive steps. We start with the specific language of the Amendment: the end of slavery and involuntary

${ }^{184}$ See, e.g., Amar, Intratextualism, supra note 6, at 823; Caminker, supra note 6, at 1158-65; Engel, supra note 70, at 141-45; Douglas Laycock, Conceptual Gulfs in City of Boerne v. Flores, 39 WM. \& MARY L. REV. 743, 754-55 (1998); McConnell, Originalism, supra note 113, at 957-62.

${ }^{185}$ Considering the clear importance of the Civil Rights Act for understanding Section Five, the failure of any Justice - in the majority or the dissent-to address the issue in Boerne reveals a parallel to Miller's opinion for the Court in SlaughterHouse, he conspicuously ignored the Act.

${ }^{186}$ CONG. GLOBE, 39th Cong., 1st Sess. 77 (1865). See also id. at 475 (1866) (Trumbull argued that the Amendment granted Congress the power to "pass any law which, in our judgment, is deemed appropriate, and which will accomplish the end in view, secure freedom to all people in the United States.").

187 See, e.g., id. at 41 (statement of Sen. Sherman); id. at 1118 (statement of Rep. Wilson). See Engel, supra note 70, at 133. Cf. Maltz, The Constitution and Nonracial Discrimination, supra note 113, at 259. 
servitude. We then move, by interpretation of this specific language, to the point that the end of slavery meant the establishment of freedom. Freedom, however, is too broad a concept to have meaning in particular situations without more legal development. Someone had to do the developing. Congress, as the enforcing authority under the Amendment, was properly authorized to fill the broad concept of freedom with the particularity necessary for legal implementation and, ultimately, for the social reification of freedom.

Rather than asking us to make the first interpretive step from the specific to the general, as the Thirteenth Amendment does, the Fourteenth Amendment starts with the general (Privileges or Immunities). Like the concept of freedom, however, the phrase "privileges or immunities" is too general for specific application without more legal analysis. Congress, having the same enforcing power under the Fourteenth Amendment as it does under the Thirteenth, would be the proper body to give the general term its concrete meanings through legislation. By beginning with the general concept, Section One of the Fourteenth Amendment is more obviously drafted with an intent to require interpretive enforcement than even the Thirteenth Amendment, upon which the Civil Rights Act was based. Or said another way, it requires less interpretive work to derive congressional power to interpret Privileges or Immunities from the Fourteenth Amendment than it does to derive congressional power to pass the Civil Rights Act from the anti-slavery language of the Thirteenth. Since the Drafting Congress believed it had this power under the Thirteenth, it must have believed it had the power under the Fourteenth.

Discussion of the congressional understanding of its powers to pass the Civil Rights Act under the Thirteenth Amendment would be incomplete without some mention of Representative Bingham's constitutional objections to the Act. Bingham doubted that Congress had the power to pass the Act under the Enforcement Clause of the Thirteenth Amendment. Essentially he doubted the interpretive position discussed above. Thus, he contended that the Fourteenth Amendment, which he was drafting, would give Congress the power to pass the Act. ${ }^{188}$ Presumably this was so because Section One's Privileges or Immunities Clause encompassed the rights established in the Act. One could argue that such doubts about the constitutionality of the Act in fact led to passage of the Fourteenth Amendment, ${ }^{189}$ and further that these doubts about the Thirteenth show that

${ }^{188}$ See CONG. GLOBE, 39th Cong., 1st Sess. 1291 (1866); see also Aynes, On Misreading John Bingham, supra note 93, at 72-73.

${ }^{189}$ See, e.g., RAOUL BERGER, GOVERNMENT BYTHE JUDICIARY:THE TRANSFORMATION OF THE FOURTEENTH AMENDMENT 113-14 (1977). 
the interpretive powers assumed by Congress in passing the Act were not to become part of the Fourteenth Amendment.

This argument founders in several respects. First, the vast majority of the supporters of the Fourteenth Amendment also voted for the Act; Bingham had doubts, others did not. Second, Bingham in fact did not vote against the Act when Congress overrode the veto. Instead, he paired with another representative and effectively avoided a vote. Third, it is entirely possible for Bingham to have rejected the interpretive leaps involved in deriving the Civil Rights Act from the Thirteenth Amendment and yet to have approved (as he later would) of the congressional interpretive power over privileges or immunities. As discussed above, the interpretive leap is greater when beginning with the more specific language of the Thirteenth Amendment than it is when the starting point is the general language of the Fourteenth. It seems entirely plausible that Bingham employed the general language of privileges or immunities in Section One in part to avoid the impediments to congressional interpretive powers that he identified in the specific language of the Thirteenth Amendment.

\section{B. Anti-Peonage Act and the Principle of Interpretive Enforcement}

Even if we give significant interpretive weight to Bingham's concerns about whether the Enforcement Clause of the Thirteenth Amendment permitted enactment of the Civil Rights Act of 1866, the Thirty-ninth Congress asserted its interpretive authority under Section Two again in legislation passed simultaneously with the ratification of the Fourteenth Amendment. ${ }^{190}$ Like the Civil Rights Act, the Anti-Peonage Act of $1867^{191}$ is particularly relevant because it involved congressional use of its enforcement powers under the Thirteenth Amendment and demonstrated a congressional willingness to interpret the constitutional amendment for itself in order to address particular instances of perceived violations of the principles of the amendment. Unlike the Civil Rights Act, however, supporters of the Fourteenth Amendment did not object to the congressional interpretive powers to pass the Anti-Peonage Act. ${ }^{192}$ Moreover, because

${ }^{190}$ The Anti-Peonage Act was passed by the Senate on February 19, 1867, and by the House on March 2, 1867. Seventeen states had ratified the Amendment by January 1867 , five more by June 1867 , and six more by July 1868 . NELSON, supra note 118 , at 59 .

${ }^{191}$ Anti-Peonage Act, 14 Stat. 546 (1867).

${ }^{192}$ Interestingly, Representative Bingham spoke in favor of the Anti-Peonage Act despite its arguably broad interpretation of the language of the Thirteenth Amendment. See CONG. GlOBE, 39th Cong., 2d Sess. 1770 (1867). (I thank 
this Act was debated and passed at the same time that the American people were actively debating the ratification of the Fourteenth Amendment with its identical enforcement clause, we may be able to garner some information about how the congressional powers can be understood under the Fourteenth Amendment.

Peonage was a system of forced labor employed in the United States territories influenced by Spanish law and practices. Under the system, workers were compelled to labor, often at threat of state coercion, in order to satisfy a debt or to fulfill an employment contract. ${ }^{193}$ The Act itself named New Mexico as the primary locus of the outlawed system, but the Act applied throughout the entire United States. ${ }^{194}$ The Act is often seen simply as a logical enforcement of the Thirteenth Amendment; the Supreme Court read it this way thirty-eight years later when it upheld the constitutionality of the Act. ${ }^{195}$ This reading makes sense, but it also tends to paper over one aspect of the law that makes it more intriguing than it initially appears. The Act does not precisely parallel the language of the Thirteenth

Richard Aynes for bringing Bingham's support to my attention.)

${ }^{193}$ On peonage in the Southwest in the 1860 s, see Lawrence R. Murphy, Reconstruction in New Mexico, 43 N.M. HIST. REV. 99 (1968). On peonage in the American South after Reconstruction and applications of the Peonage Act, see WILLIAM COHEN, AT FREEDOM's EDGE: BLACK MOBILITY AND THE SOUTHERN WHITE QUEST FOR RACIAL CONTROL 1861-1915, 274-98 (1991); PETE DANIEL, The Shadow of Slavery: PeONaGe IN THE SOUTH, 1901-1969 (1972); Pete Daniel, The Metamorphosis of Slavery, 1865-1900, 66 J. AM. HIST. 88 (1979). On Peonage in the South after Clyatt v. United States, see Risa L. Goluboff, "Won't You Please Help Me Get My Son Home": Peonage, Patronage, and Protection in the World War II Urban South, 24 LAW \& SOC. INQUIRY 777 (1999). See generally Benno C. Schmidt, Jr., Principle and Prejudice: The Supreme Court and Race in the Progressive Era. Part 2: The Peonage Cases, 82 CoLUM. L. REV. 646 (1982).

${ }^{194}$ The Act states:

[T] he holding of any person to service or labor under the system known as peonage .... is hereby abolished and forever prohibited in the Territory of New Mexico, or in any other Territory or State of the United States; and all acts, laws, resolutions, orders, regulations, or usages of the Territory of New Mexico, or of any other Territory or State "of the United States," which have heretofore established, maintained; or enforced, or by virtue of which any attempt shall hereafter be made to establish, maintain, or enforce, directly or indirectly, the voluntary or involuntary service or labor of any persons as peons, in liquidation of any debt or obligation, or otherwise, ... [are] declared null and void.

Anti-Peonage Act, 14 Stat. 546 (1867).

${ }^{195}$ Clyatt v. United States, 197 U.S. 207, 218 (1905). 
Amendment, which outlaws slavery and involuntary servitude. ${ }^{196}$ Instead, it proscribes "voluntary and involuntary service or labor" in peonage. This was not a simple oversight. Senator Davis objected that Congress did not have authority to address voluntary servitude. Despite his objection, the language remained. ${ }^{197}$

By encompassing voluntary arrangements, the Act arguably takes the Amendment one step beyond its literal reading in an effort to prevent arrangements that have the appearance of volition, such as those entered into under contract, from being used as ruses to compel labor. One could interpret the fact that payment of the debt would extinguish the service as evidence that peonage was unlike either slavery or involuntary servitude. But that was not Congress' interpretation in passing the Act. As the Supreme Court later recognized, elements of peonage that could be deemed voluntary might nonetheless amount to compulsion. The Court therefore approved what seems a liberal constitutional interpretation by Congress, showing particular deference to congressional interpretation. ${ }^{198}$

The Anti-Peonage Act provides additional evidence of a general acceptance of broad congressional interpretation of the language of the Reconstruction Amendments and its own powers thereunder. Congress' use of its enforcement power to interpret "involuntary servitude" to include certain "voluntary" agreements occurred simultaneously with the debates over ratification of the Fourteenth Amendment, a time when there was heightened attention to and a revolution of the bounds of congressional

196 U.S. CONST. amend. XIII.

${ }^{197}$ CONG GLOBE, 39th Cong., 2d Sess. 1571 (1867).

${ }^{198}$ Clyatt, 197 U.S. at 215-16. See also United States v. Reynolds, 235 U.S. 133 (1914); Bailey v. Alabama, 219 U.S. 219, 240-44 (1911). It is especially significant that the Court accepted congressional interpretation of an issue-illusory volition in employment contracts- that the same Court (the Court of the "Lochner Era") is perceived to have interpreted quite differently in other contexts. See, e.g., Dennis D. Hirsch, The Right to Economic Opportunity: Making Sense of the Supreme Court's Welfare Rights Decisions, 58 U. PITT. L. REv. 109, 114-23 (1996) (contrasting the Lochner Era Court's assumptions that workers and employers were equal bargainers with the New Deal Court's willingness to allow legislatures to presume that workers were not contracting in a state of real freedom). This interaction between the Court and Congress on the interpretation of the Thirteenth Amendment nicely illustrates the type of relationship the modern Court seems to reject. See, e.g., United State v. Morrison, 529 U.S. 598 (2000); City of Boerne v. Flores, 521 U.S. 507 (1997). On how this relationship might work, see McConnell, Institutions and Interpretation, supra note 6, at 184-94. 
power. ${ }^{199}$ Moreover, this action by Congress was likely to affect areas traditionally reserved to states: contract enforcement, debt, and labor. Congress apparently believed that such "encroachment" into these areas was permitted when the offensive labor arrangement at issue came within what Congress perceived to emanate from the basic principles (rather than a strict construction of the language) of the Thirteenth Amendment.

What can we conclude from this episode? One might contend that the differences between the substantive provisions of the Thirteenth and Fourteenth Amendments caution against too great a comparison. The former Amendment contains no "state action" limitation, and so allows Congress broader power to regulate the substantive area and not just to respond to what the states did. But if Congress has the sort of interpretive power that it showed with the Anti-Peonage Act, it should have some flexibility both to determine the precise content of the Privileges or Immunities Clause and to determine what actions (or inaction) by states trigger its powers. Indeed, congressional interpretation of "involuntary servitude" to include voluntary arrangements seems more, not less, aggressive than would congressional efforts to establish a particular privilege or immunity under the very broad phrase "Privileges or Immunities" or to assert that public inns operate under state authority sufficient to trigger the state action requirement. ${ }^{200}$ For the language of the Reconstruction Amendments to be viable someone has to do some interpretive work; the Anti-Peonage Act shows that Congress was willing to do so.

The fact that Congress took such an interpretive step under its enforcement powers during the time of ratification of the Fourteenth Amendment also indicates at least an implicit acceptance of this type of interpretive role for Congress by those who ratified the Amendment. This point can only be made guardedly; it relies on negative inference since the Anti-Peonage Act does not seem to have attracted much attention. ${ }^{201}$ At the time the Act was presented and passed, Congress was deeply enmeshed in the Reconstruction Act of 1867, which set the terms by which the former

${ }^{199}$ See supra note 124 (discussing white Southern concerns for congressional powers under Section Five as central to Southern States' opposition to ratification of the Fourteenth Amendment).

${ }^{200}$ See infra Part III, discussing the Civil Rights Act of 1875.

${ }^{201}$ Apparently neither the New York Times nor Harper's Weekly noted the act during the period of its adoption (Feb. and Mar. 1867); both publications discussed other congressional activities in some detail and cited specific legislative actions. See generally N.Y. TIMES, Feb.-Mar., 1867; HARPER's WEEKLY, Feb.Mar., 1867. 
Rebel states would re-gain representation; ${ }^{202}$ the Anti-Peonage Act seems to have been a sideshow. Nonetheless, it is more reasonable to conclude that this type of congressional interpretation through legislation was viewed as consistent with the enforcement clauses of the Reconstruction Amendments than to assume the opposite. ${ }^{203}$

\section{Enforcement Act of 1871}

After the Fourteenth Amendment became ratified in 1868, Congress began implementing its interpretation of the Amendment and the powers granted to Congress under Section Five. The first two instances of this interpretive, implementing legislation occurred in 1870 and 1871. From 1868 through $1871 \mathrm{Ku}$ Klux Klan violence ravaged the South and partly succeeded in destroying the nascent political and economic power of African-Americans and Republicans. ${ }^{204}$ State and local governments were either unwilling or unable to counter this violent intimidation. If violence and lawlessness were to be overcome, it would be through federal laws and enforcement. Congress and some northern Republicans had grown weary of Reconstruction and federal efforts in the South, but this new wave of violence stirred them into action. Congress passed a series of acts to protect blacks, primarily in the area of voting. The 1871 Act, for instance, created a limited federal criminal law and punished conspiracies to deprive citizens of their rights to vote, serve on juries, and obtain equal protection of the law. As Eric Foner has stated, this shift of criminal law over private conduct from the exclusive jurisdiction of the states to the shared power of the federal government "pushed Republicans to the outer limits of constitutional change."205 Opponents repeated their well-worn refrain that such centralization would be the end of state and local government. ${ }^{206}$

Speeches by supporters of the Enforcement Act, who also participated in the 1866 debates over the Amendment, serve as good examples of the arguments in favor of their broad understanding of the Reconstruction Amendments, both in substance and in the enabling of congressional power. Representative Shellabarger, in his extensive speech supporting the initial version of the Enforcement Act, asserted that the Fourteenth

${ }^{202}$ The Reconstruction Act itself asserted an expansive view of federal powers. See FONER, supra note 114, at 271-80.

${ }^{203}$ Congressional enforcement powers were an important issue for southern officials opposed to ratification of the Fourteenth Amendment. See supra note 124.

${ }^{204}$ This summary relies largely on FONER, supra note 114, at 425-59.

${ }^{205} \mathrm{Id}$. at 455.

${ }^{206} \mathrm{Id}$. 
Amendment empowered Congress "to directly protect and defend throughout the United States those privileges and immunities which are in their nature "fundamental"" and to "legislate directly for enforcement of such rights as are fundamental elements of citizenship."207 Thus Shellabarger adopted both a natural rights interpretation of the Privileges or Immunities Clause (he quoted from Corfield in the same speech) and a strong view of congressional powers under Section Five, and saw them as mutually reinforcing. In particular, Shellabarger emphasized the establishment of national citizenship in Section One (in its opening sentence), and argued that this national citizenship and its concomitant privileges and immunities, combined with congressional empowerment, gave Congress the power to protect privileges and immunities for citizens of the nation. ${ }^{208}$ Since the Act itself punished conspirators who sought to abridge "rights, privileges, or immunities," the Act seemed, to Shellabarger, quite consistent with the powers under the Amendment. ${ }^{209}$. Others shared Shellabarger's view of the scope of congressional powers to implement national privileges of citizenship. ${ }^{210}$

Shellabarger then responded to calls that the Act entrenched on states' powers by arguing that this assumed that the two governments, federal and state, could not have concurrent jurisdiction. Here, Shellabarger set forth one of the most significant Reconstructionist views of the Fourteenth Amendment. The Amendment, according to Shellabarger, contemplates concurrent jurisdiction over privileges and immunities. In an effort to assuage those concerned that this was an entirely new construction of American governmental powers, and to explain how such a dual jurisdiction might operate, he pointed out that the Supreme Court had long permitted both state and federal governments to hold the power to punish counterfeiting. To the extent that the fundamental rights of citizenship were at issue, the Fourteenth Amendment established a similar dual jurisdic-

${ }^{207}$ CONG. GLOBE, 42d Cong., 1st Sess. app. 69 (1871).

${ }^{208} \mathrm{Id}$.

${ }^{209}$ This portion of the initial version of the Bill was changed in the final version. See Michael P. Zuckert, Congressional Power Under the Fourteenth Amendment-The Original Understanding of Section Five, 3 CONST. COMM. 123, 149-50 (1986).

${ }^{210}$ See CONG. GLOBE, 42d Cong., 1st Sess. 334 (1871)(statement of Rep. Hoar) ("Congress is empowered by the fourteenth amendment to pass all 'appropriate legislation' to secure the privileges and immunities of the citizen," and those privileges and immunities include those expressly in the Constitution and those "fundamental and essential to citizenship." (citing Corfield v. Coryell, 6 F. Cas. 546 (C.C.E.D. Pa. 1823) (No. 3230))). See also FONER, supra note 114, at 455. 
tion. ${ }^{211}$ Shellabarger was therefore trying to move Congress beyond a separate sphere conception of governmental powers toward a more nuanced view of shared powers. The Supreme Court would struggle with this problem of concurrent jurisdiction in Slaughter-House and its progeny, but in 1871 some Republicans believed this had been settled by the Amendment in favor of joint jurisdiction. Finally, Shellabarger set forth a common Republican argument in favor of Congressional power: Congress previously exercised such power to enforce the Constitution when it passed antebellum fugitive slave acts. ${ }^{212}$ If the Constitution permitted Congress to enforce the Fugitive Slave Clause (which contained no enforcement provision of its own) with affirmative legislation directed against individuals, then surely Congress could legislate to protect the privileges and immunities of national citizenship through Section Five of the Fourteenth Amendment. ${ }^{213}$

Representative Bingham also addressed the relationship of the Enforcement Act to the Fourteenth Amendment. He engaged in a fascinating exchange with Representatives Farnsworth and Garfield, who both asserted that the Fourteenth Amendment did not empower Congress to act directly, but only to respond to laws of the states. ${ }^{214}$ Farnsworth and Garfield relied heavily on the fact that in 1866 Congress had not adopted the draft version of Section One, prepared by Bingham, which stated:

The Congress shall have power to make all laws which shall be necessary and proper to secure to the citizens of each State all privileges and immunities of citizens in the several States, and to all persons in the several States equal protection in the rights of life, liberty, and property. ${ }^{215}$

${ }^{211}$ CONG. GlOBE, 42d Cong., 1st Sess. 70 (1871). Interestingly, the case cited for this point, Moore v. Illinois, 55 U.S. (14 How.) 13, 20 (1852), while indeed asserting the principle regarding counterfeiting, was not a counterfeiting case, but a fugitive slave case. In Moore the Court upheld Illinois' punishment of a state citizen for harboring a person who was enslaved in another state. The plaintiff had argued that his act was only properly within the jurisdiction of the federal government under the Fugitive Slave Clause. The Court rejected this view and permitted a dual jurisdiction to protect slave owners. Thus, Shellabarger was indirectly also making the point, similar to the assertion regarding federal powers under the Fugitive Slave Clause, that dual sovereignty presented no obstacle for antebellum states' rightists when used to support slavery.

${ }^{212}$ CONG. GlOBE, 42d Cong., 1st Sess. 70 (1871).

${ }^{213}$ Justice Harlan also relied on this argument in dissent in the Civil Rights Cases. See infra note 328.

${ }^{214}$ CONG. GLOBE, 42d Cong., 1st Sess. app. 81-86, 115-17 (1871). See Zuckert, supra note 209 , at $123-25$.

${ }^{215}$ CONG. GLOBE, 39th Cong., 1st Sess. 1034 (1866). 
The House voted to postpone consideration of this version, and the version eventually passed by the House and Senate-the one now in the Constitution-contains the familiar "No state shall" language in Section One with Section Five asserting congressional power to "enforce" the Amendment with appropriate legislation. In 1871, Farnsworth and Garfield argued that the powers claimed for congressional legislation in the original draft were rejected by the House and the final, ratified Amendment avoided such a broad grant of power. Bingham replied that the final version, which he also wrote, "embraces all and more than did the February proposition" in that the draft did not expressly prohibit the states from violating privileges and immunities and the final version both empowered Congress and prohibited the states. ${ }^{216}$ This debate is not just of historical importance; the Supreme Court relied on Garfield and Farnsworth's analysis in its restrictive interpretation of Section Five in City of Boerne v. Flores. ${ }^{217}$

Bingham's position has been substantially supported by scholars. Michael Zuckert wrote a detailed examination of the voting patterns and arguments of those in Congress in both 1866 and 1871, concluding that Bingham's position was consistent with the majority of those who were

${ }^{216}$ CONG. GLOBE, 42d Cong., 1st Sess. app. 83 (1871).

${ }^{217}$ City of Boerne v. Flores, 521 U.S. 507, 521-22 (1997). Indeed, the Court in Boerne arguably went farther than rejecting an expanded role of Congress under Section Five and read the drafting changes to support its own restriction of congressional action, so that instead of applying the traditional $\mathrm{McCulloch}$ "necessary and proper" test to the validity of congressional action, the Boerne Court demands that, under Section Five, such action be congruent and proportional to the power under Section One. Id. at 519. See generally Caminker, supra note 6; Engel, supra note 70 . It is a truly odd reading of the historical record to conclude that a Congress as doubtful of the post-Dred Scott Supreme Court's constitutional interpretations as was the 39th Congress would decide to grant itself less interpretive power under the Fourteenth Amendment than it has under Article I, choosing instead to rely on the wisdom of the Justices. See Caminker, supra note 6, at 1163; Engel, supra note 70, at 128-29; Fox, supra note 24, at 512-13; McConnell, Institutions and Interpretation, supra note 6, at 182 (Boerne is a "dubious reading" of the historical record); Nowlin, supra note 182, at 443-44 ("period from Dred Scott through Reconstruction was an era of intense Republican disillusionment with - and often outright hostility toward - the federal courts"). It also places the Court in the awkward position of interpreting congressional powers under the identical Enforcement provisions of the Thirteenth and Fourteenth Amendments significantly differently. See Amar, Intratextualism, supra note 6, at 822-23. 
present at both periods. ${ }^{218}$ At the very least, the argument that the draft was rejected because it granted too much power to Congress is not adequately supported. It is more likely that Garfield and others were themselves rewriting history in an effort to back away, for political reasons, from the more radical approach of the Republicans of the $1860 \mathrm{~s}^{219}$

Thus Bingham's views in 1871 probably provide a more reliable guide to the original ideas behind the Fourteenth Amendment than do the views of those who criticized the Enforcement Act of 1871; they also offer us an interpretation of the Amendment in the context of congressional particularization of the Amendment's generalities. Bingham believed that the Reconstruction Amendments expanded protection of civil rights: "[these Amendments] vest in Congress a power to protect the rights of citizens against States, and individuals in States, never before granted."220 He described Section Five of the Fourteenth Amendment as a "grant of power" that was "full and complete,"221 and argued that the privileges and immunities of American citizenship (quoting verbatim first eight Amendments) "may be enforced under existing laws of Congress, and such other laws for their better enforcement as Congress may make."222 Bingham thus asserted a congressional power to make laws to secure the privileges and immunities of national citizenship. On the content of the Privileges or Immunities Clause, however, Bingham remained close to a textualist reading that incorporated the Bill of Rights (which he repeatedly refers to in the speech), but did not add any further rights. For this reason, those

${ }^{218}$ See Zuckert, supra note 209. See also Fox, supra note 24, at 506-13; Kaczorowski, Revolutionary Constitutionalism, supra note 82, at 914-15. Notably, Garfield and Farnsworth eventually voted for the Enforcement Act, even though it contained language directed against private individuals. Zuckert, supra note 209, at 148 (Garfield and Farnsworth voting); id. at 150 (private conduct scope of act).

${ }^{219}$ KACZOROWSKI, POLITICS OF JUDICIAL INTERPRETATION, supra note 26, at 163-65. Eric Foner observes that Republican support for civil rights waned after ratification of the Fifteenth Amendment, in part because, according to Garfield, the vote placed African-Americans" "fortune in their own hands." FONER, supra note 114, at 449 (quoting Garfield). On the shift of some members of the Republican Party away from Radical Reconstruction and toward Gilded-Age Liberalism (including the formation of the Liberal Republican Party and alliance with the Democratic Party in 1872), see $i d$. at 486-511. See also PAMELA BRANDWEIN, RECONSTRUCTING RECONSTRUCTION: THE SUPREME COURT AND THE PRODUCTION OF HISTORICAL TRUTH 81-85 (1999).

${ }^{220}$ CONG. GLOBE, 42 d Cong., 1st Sess. app. 83 (1871).

${ }^{221} \mathrm{Id}$.

222 Id. at 84. 
scholars who focus on incorporation of the Bill through the Privileges or Immunities Clause highlight his speech, and rightly so. ${ }^{223}$ But they do not address Bingham's focus on congressional empowerment. I do not believe that Bingham affirmatively rejected broader readings of the Privileges or Immunities Clause, ${ }^{224}$ and that even if he had, his emphasis on congressional empowerment reflects his concern with the need for federal legislation to enforce the Privileges or Immunities Clause to make real the promises of the Amendment. It indicates that the real work of the Amendment was, for him, not so much "incorporation," as what Congress would do with incorporation. The bulk of his speech (coming as it does as argument favoring the Enforcement Act) addressed this question of federal legislative powers and duties: "The people of the United States are entitled to have their rights guaranteed to them by the Constitution of the United States, protected by national law."225

The version of the Enforcement Act discussed by Shellabarger and Bingham was revised, however, so that instead of criminally punishing conspiracies to violate "rights, privileges, or immunities of another person," the final Act prohibited conspiracies to deprive people of "the equal protection of the laws, or of equal privileges or immunities under the laws." ${ }^{226}$ Some congressmen objected that the original Bill was overbroad in that it might supersede state laws, but were willing to vote for the final version which enforced an equality of those state laws (although both versions addressed private action). ${ }^{227}$ As Shellabarger stated in presenting this Amendment, the purpose of the amendment was "to confine the

${ }^{223}$ See, e.g., AMAR, THE BLL OF RIGHTS, supra note 24, at 183; CURTIS, No STATE SHALl ABRIDGE, supra note 24, at 161-62; Newsom, supra note 3, at 698.

${ }^{224}$ At the end of his speech, Bingham suggests an expansive interpretation of liberty: "It is the liberty, sir, to work in an honest calling and contribute by your toil in some sort to the support of yourself, to the support of your fellow men, and to be secure in the enjoyment of the fruits of your toil." CONG. GLOBE, 42d Cong., 1st Sess. app. 86 (1871). Bingham's invocation of the right to labor as a fundamental liberty sounds much like Justice Bradley's dissent in Slaughter-House and echoes a Lincolnian free labor vision. Similarly, Bingham introduced the list of the Bill of Rights by stating that the privileges and immunities of citizens were "chiefly defined in the first eight amendments. ..." Id. at 84. The use of "chiefly" indicates that there were other possible sources for privileges and immunities. I thank Richard Aynes for this latter point.

${ }^{225} \mathrm{Id}$. at 85.

${ }^{226}$ Id. at 68-69 with Enforcement Act, 17 Stat. 13 (1871). See also Zuckert, supra note 209 , at $148-50$.

${ }^{227}$ Zuckert, supra note 209 , at $148-54$. 
authority of this law to the prevention of deprivations which shall attack the equality of rights of American citizens; that any violation of the right, the animus and effect of which is to strike down the citizen, to the end that he may not enjoy equality of rights as contrasted with his and other citizens' rights, shall be within the scope [of this law]."228 Thus it appears that Congress decided to address the deprivation of equality in privileges and immunities and not the deprivation of privileges and immunities per se.

This change may, and Shellabarger and others seem to have understood it to, limit the scope of what was protected, but it is not clear what the practical effect of this change could be. Representative Williard, who opposed the original version on constitutional grounds, yet accepted the revision, asserted that the original version would have given the United States jurisdiction over all crimes, whereas the revised version gave jurisdiction only over denial of equal privileges and immunities and equal protection. ${ }^{229}$ The basic point was to prevent the Act from enabling federal prosecution for all crimes. However, a conspiracy to prevent voting denies both the privilege of voting and the equal application of the privilege to the victim vis-a-vis other voting citizens. Moreover, the change in favor of the equality language was made to the criminal portion of Section Two of the

${ }^{228}$ CONG. GLOBE, $42 \mathrm{~d}$ Cong., 1st Sess. 478 (1871).

${ }^{229}$ CONG. GLOBE, 42d Cong., 1st Sess. app. at 188 (1871). Others who commented after the change continued to set forth a broad view of the Act and the Fourteenth Amendment. Representative Wilson asserted that the privileges protected by the Act were "fundamental" privileges, including those articulated in the Constitution (freedom from slavery and right to vote) and even those not so clearly within the Constitution, such as the right to seek employment in a state. CONG. GLOBE, 42d Cong., 1st Sess. at 482, 484. Representative Cook asserted that Congress could "protect and enforce every right secured to American citizens by the Constitution," and that the "right to support and advocate the election of any qualified person to any office under the United States Government" was a right of American citizenship. Id. at 485-86. Similar statements were made in the Senate. Senator Frelinghuysen contended that the Fourteenth Amendment established "fundamental rights" and privileges and immunities which the federal government could enforce, and, more strongly, that " $[t]$ he fourteenth amendment goes much further than establishing 'equality' between blacks and whites [which the Civil Rights Act of 1866 did]. It asserts United States citizenship and defines some of its privileges and immunities." Id. at 500 . Some of the opposition to the Bill by Democrats reflects their persistent effort to minimize the effect of the Amendments that they opposed in the first place. Naturally, they sought to limit the scope of the Privileges or Immunities Clause and also to narrow congressional powers under Section Five. See, e.g., CONG. GlOBE, 42d Cong., 1st Sess. app. at 47-48 (1871) (statement of Rep. Kerr) (limiting Privileges or Immunities Clause to the sojourn protection of Article IV and the simple equality of citizens within a state). 
Act addressing private conspiracies, but not to Section One addressing state officers. The change was also not made to the civil portion of Section Two where the Act stated that anyone "injured in his person or property, or deprived of having and exercising any right or privilege of a citizen of the United States" because of the acts in furtherance of the conspiracy would have an action for damages. ${ }^{230}$ Thus, both the state actor provisions and the civil damage portion of the Act seem to indicate that a deprivation of rights and privileges per se, not just a deprivation of equality of those rights and privileges, is covered by the Act, and Congress was simply limiting the criminal portion of the Act as applied to private actors. Nonetheless, the congressional debates can fairly be read to reflect a general understanding that the Fourteenth Amendment was not intended to vest the federal government with authority over all criminal acts, but only to focus on the denial of those things protected by the Constitution, including fundamental privileges and immunities. ${ }^{231}$ As Professor Curtis has observed, "[f]or the federal government to take over the vast domain of state law was unacceptable. For states to violate or leave unprotected the basic rights of citizens was equally unacceptable to Republicans. The Fourteenth Amendment had sought to reconcile these two competing interests."232

In 1871, Congress was struggling to resolve, in legislation, these competing interests. ${ }^{233}$ Congressional debates over how Congress could

${ }^{230}$ See Enforcement Act, 17 Stat. 13, 14; see also CONG. GLOBE, $42 \mathrm{~d}$ Cong., 1 st Sess. 477 (1871).

${ }^{231}$ Altematively, one could argue that the shift from "rights, privileges, or immunities," to "privileges or immunities under the laws," was designed to shift away from Shellabarger's original enforcement of fundamental privileges to a more limited protection of privileges established in "laws," perhaps meaning statutes. There is no clear indication that this was the purpose of the change, however. Shellabarger himself asserted that the privileges and immunities covered by the final version were the "rights of American citizens" and "citizens' rights," which seems to encompass both fundamental rights and rights established by statute and case law. It is possible that the revised version was intended to protect only those privileges and immunities clearly established in law rather than those that a federal court might "create" on its own in an enforcement action. According to this reading, "fundamental" privileges would be protected to the extent that they had protection already at law but a court could not assert a new protection on its own. Note, however, that this latter interpretation only restricts the courts in "creating" privileges of citizenship; a privilege created by statute would still be protected.

${ }^{232}$ CURTIS, No STATE SHALl ABRIDGE, supra note 24, at 157.

${ }^{233}$ This tension is evident in Representative Hoar's comments on the Enforcement Act:

I believe in the right to exercise the national power for the protection of the fundamental right of the citizen. I believe that was the purpose of the 
address the violence of the $\mathrm{Ku} \mathrm{Klux}$ Klan reflect an important effort to develop, jurisprudentially and politically, the new post-war federalism of the Reconstruction Amendments, especially the Fourteenth. Shellabarger spoke initially about a dual sovereignty; the debates among Republicans over the changes to the Bill focused on how to create federal enforcement without completely overtaking state law. ${ }^{234}$ As Michael Zuckert perceptively observed several years ago, the resolution to this question, offered by John Bingham and others, was the de Tocquevillian realization that America had "centralized government, decentralized administration": the Constitution establishes uniform laws and rights of Americans, and states localize the law. ${ }^{235}$ According to Zuckert, Bingham believed:

[T]he states need not cease making the laws that secure and regulate the privileges and immunities of citizens, the life, liberty, and property of persons. The states ... although retaining the primary care for all these matters, yet are to be subject to the national standards as defined in the Constitution and applied by courts and Congress. ${ }^{236}$

Constitution, to put the fundamental civil rights of the States beyond the power of any lesser power to destroy them.

... I do not favor interference in any degree by the national Government with the local administration.

CONG. GLOBE, 42 Cong., 1st Sess. app. 117 (1871).

${ }^{234}$ See Hyman \& Wiecek, supra note 97 , at 471; cf. Benedict, supra note 82, at 47.53 (discussing the Reconstruction Congress' efforts to balance federalism and nationalism, and arguing that Congress in fact sought to preserve states' rights).

${ }^{235}$ Zuckert, supra note 209, at 139-41 (citing Bingham in CONG. GLOBE, 42d Cong., 1st Sess. app. 84-85 (1871)).

${ }^{236}$ Id. at 141. See also CONG. GLOBE, 42d Cong., 1st Sess. 334 (1871) (statement of Rep. Hoar):

Another error ... is to suppose that Congress ... must either let the State alone altogether, or take entire possession of all its powers and instrumentalities of government. ... But there is nothing in the Constitution that for a moment favors that idea. We have a right to limit our interference to the extent of the evil. If a particular class of persons are denied their civil rights permanently and as a rule in any State, we have a right to interfere simply to protect those rights....

Id. The debate between Senator Trumbull, who supported the Fourteenth Amendment but voted against the Enforcement Act, and Senator Carpenter, who later represented the government in Slaughter-House, is also instructive on this point. Trumbull generally takes the position (contrary to his statements from 186566) that the Fourteenth Amendment did not change the Constitution with respect to individual rights; Carpenter advocates in favor of congressional powers to protect citizens rights. See id. at 576-78. Cf. CONG. GLOBE, 39th Cong., 1st Sess. 
Thus, we see in the debates among those who favored the Enforcement Act of 1871, an effort to address the issue that so perplexed Justice Miller in Slaughter-House, and continues to perplex the Slaughter-House revisionists: does a broad interpretation of privileges and immunities render state sovereignty obsolete? Interestingly, Justice Bradley's circuit opinion in the Slaughter-House Cases, which the Supreme Court overturned, was cited favorably by advocates of the Enforcement Act for its interpretation of the Privileges or Immunities Clause. ${ }^{237}$ Advocates of the Act therefore had some awareness of the potentially broad understanding of the Amendment that the Slaughter-House dissenters would latter advocate, and yet they saw it as consistent with their own interpretation of the Amendment.

The debates over congressional powers regarding the Enforcement Act do not by any means resolve the issue. Nor could we expect them to resolve it. The scope of federal powers in a dual, overlapping sovereignty was then, and likely will always be, nettlesome and unsettled, and the Forty-second Congress was the first generation to attempt to implement the potentially enormous changes wrought by the war. To expect a clear answer that adequately addressed the concerns of both over-centralization and the nonprotection of citizens' rights would be to expect the impossible. Nonetheless, the debates reveal a range of considerations prevalent within Congress regarding the Fourteenth Amendment.

First, there was a general understanding among supporters of the Act that Section Five of the Fourteenth Amendment granted Congress power to protect citizens in their privileges and immunities. In a sense; this observation is tautological, since Congress would be expected to think it had the power to pass the Act that it passed. Notably, however, the final Act included a proscription on private conduct, thus indicating congres-

77 (1865) (in supporting the 1866 Civil Rights and Freedmen's Bureau Bills, Trumbull declared that the Thirteenth Amendment gave Congress the power "to protect every person in the United States in all the rights of persons and property belonging to a free citizen."). On Trumbull's about-face on the Fourteenth Amendment and the Civil Rights Act of 1866, see KACZOROWSKI, POLITICS OF JUDICIAL INTERPRETATION, supra note 26, at 164 and n.69.

${ }^{237}$ See CONG. GLOBE, 42d Cong., 1st Sess. 500 (1871) (statement of Sen. Frelinghuysen); id. at 334 (statement of Rep. Hoar). After citing Bradley's opinion, Representative Hoar further argued that the Privileges or Immunities Clause "comprehends all the privileges and immunities declared to belong to the citizen by the Constitution itself. Most clearly, also, it seems to me, it comprehends those privileges and immunities which all Republican writers of authority agree in declaring fundamental and essential to citizenship." Id. 
sional assertion of power over private conduct affecting privileges and immunities.

Second, the main supporters of the Act understood themselves to be promoting a new version of federalism authorized by the Reconstruction Amendments, one that accepted overlapping jurisdiction between state and federal governments over the privileges and immunities of citizens. This conception of federalism recognized states as the primary implementers and protectors of privileges and immunities, but also recognized a constitutional obligation for Congress to step in where the state governments were unwilling or unable to implement and protect the privileges and immunities of their citizens.

Finally, both of these principles beg the question: What were privileges and immunities? On this, the record of the 1871 Congress remains ambiguous. As stated above, Bingham focused on the rights contained in the Bill of Rights, although he did not clearly limit privileges and immunities of national citizenship to those. Shellabarger spoke of fundamental rights in a way reminiscent of the natural rights approach of many members of the Thirty-ninth Congress, and others cited Justice Bradley's natural rights approach favorably. Representative Willard argued that Section One of the Fourteenth Amendment gave only "equality of rights under the laws of the several States in matters within the jurisdiction of such states" and, like the Civil Rights Act of 1866, gave "no absolute rights . . except the right to equality of privileges and immunities."238 Ultimately, however, it was not necessary for Congress to resolve (or even fully air the views on) this question, since the legislation at issue simply asserted protection of privileges and immunities and did not attempt to define or particularize them. ${ }^{239}$ That would be a task for proposed legislation being debated concurrently, and seemingly perpetually, which would eventually become the Civil Rights Act of 1875 .

\section{Civil Rights Act of 1875: Pre-Slaughter-House}

The Civil Rights Act of 1875 originated in 1870. Drafted, proposed, and promoted by the dean of the radical, racial egalitarian wing of the Republican Party, Charles Sumner, the original bill went through several years of amendments and complex legislative bargaining and maneuvering,

${ }^{238}$ CONG. GLOBE, 42d Cong., 1st Sess. app. at 189 (1871).

${ }^{239}$ See, e.g., id. at 475-76 (statement of Rep. Dawes). It is also important to note that much of the debate over the Enforcement Act involved issues of state action. See CURTIS, No STATE SHALL ABRIDGE, supra note 24, at 158-60. 
eventually being passed in a relatively weak form by a lame-duck Republican Congress after Sumner's death. ${ }^{240}$ Nonetheless, the debates over the Bill and the strong support the Bill maintained through 1874, especially among those who had voted in favor of the Fourteenth Amendment, reveal a strong commitment to congressional powers to interpret the Privileges or Immunities Clause and implement its interpretation. As we shall see, the debates also reveal that the Slaughter-House Cases dampened congressional exploration of the potential of the Privileges or Immunities Clause, causing some Republicans to de-emphasize fundamental privileges in favor of a general privilege of equality.

The supporters of the Bill in the early 1870 s generally viewed the constitutional basis for the legislation as the Privileges or Immunities Clause of the Fourteenth Amendment: it was an implementation, using Congress' Section Five powers, of the privileges of United States citizenship. ${ }^{241}$ The proposed Bill itself continued the theme of the Civil Rights Act of 1866 in that it asserted the right to equal treatment. Sumner's original Bill extended the context of such equal treatment, however, to common carriers, inns, licensed theaters and public amusements, schools, churches, and cemeteries. ${ }^{242}$ Thus, the same issue we saw under the 1866 Act

${ }^{240}$ For an excellent review of the legislative history of the Civil Rights Act, see McConnell, Originalism, supra note 113, at 1049-86. See also Alfred H. Kelly, The Congressional Controversy over School Segregation, 1867-1875, 64 AM. HIST. REV.537 (1959). James McPherson's 1965 article also remains a valuable resource on the history of the Civil Rights Act. James McPherson, Abolitionists and the Civil Rights Act of 1875, 52 J. Am. HIST. 493 (1965). See also John Hope Franklin, The Enforcement of the Civil Rights Act of 1875, 6 PROLOGUE 225 (1974).

${ }^{241}$ See Kelly, supra note 240, at 548-49; McPherson, supra note 240, at 504. Supporters of the Bill also spoke in terms of equality before the law in ways that sound, to the modern ear, much like equal protection analysis. E.g., CONG. GLOBE, 42d Cong., 2d Sess. 241-43 (1871) (debate between Sens. Sumner and Hill). Prior to the Slaughter-House opinion, arguments based on equality appear to be founded both on the Privileges or Immunities Clause and the Equal Protection Clause. Sumner in particular remained imprecise on the specific Constitutional textual support for the Bill. See McConnell, Originalism, supra note 113, at 997.

${ }^{242}$ CONG. GLOBE, 41 st Cong., 2d Sess. 3434 (1870). In introducing this Bill, Sumner expressly identified it as "supplementary to" the 1866 Civil Rights Act. Id. For a full text of the Bill as first fully debated by the Senate in 1872, see CoNG. GLOBE, $42 \mathrm{~d}$ Cong., 2d Sess. 244 (1872). The 1872 citation has the complete text of the Bill when introduced as a rider to the Amnesty Bill, which was enacted to provide amnesty to southerners who retained political disability under the Fourteenth Amendment. On the complex political reasons for the pairing of Sumner's Bill with the Amnesty Bill, see McPherson, supra note 240, at 501-03. 
regarding whether the asserted privilege was simply equality or whether it was the privilege to have the thing that whites had, reappears with the 1875 Act and its drafts.

At least with one aspect of the Bill, this question was perhaps not relevant: there simply could not be an issue (before automobiles) of whether the railroads or steamboats would cease to operate and achieve equality by equal denial. Public transportation was a public necessity and once the technology had been developed and enterprises established under government grants and incorporations, the question was not one of eliminating the provision for all, but of who gets access to what. This point cannot be overstated. Much of the opposition to the Bill centered on the states' powers to eliminate the subject privileges, such as public school. This argument becomes a non-sequitur with rail travel; however, since the states were in no position to eliminate it. To the extent we can harmonize the inclusion of each subject within the Bill, it probably makes more sense to assume that the supporters viewed each topic as a guaranty, in law or in practice, to state citizens.

As to the other elements of the Bill the question is more complicated. Inns, for instance, are not so clearly a necessity, and certainly not inns in the publicly regulated sense. Sumner himself drew a distinction between a public inn and a boarding house, the latter being private and not covered by his bill. ${ }^{243}$ It is on this point that Sumner's argument about equality before the law did most of its work. The idea was that as long as particular institutions were "legal" institutions, in the sense that they were created or regulated by law, Congress could impose an obligation of equal treatment on the institution. Interestingly, Sumner connected this rationale to the privileges of citizenship: "Equality before the Law; nor more nor less; that is, that condition before the Law in which all are alike-being entitled without any discrimination to the equal enjoyment of all institutions, privileges, advantages, and conveniences created or regulated by law."244

Here the law is seen as granting privileges wherever it operates. But for Sumner the question was not so lawyerly as defining constitutionally precise language. The purpose of the Reconstruction Amendments was a grander one of fundamental political philosophy and the foundation of Republican government: it was the elimination of caste and creation of equality across all public spheres, defined as those "institutions, privileges,

See also FONER, supra note 114, at 504-05. A substantially similar bill was introduced in the House in 1872. CONG. GLOBE, 42d Cong., 2d Sess. 1116 (1872).

${ }^{243}$ McConnell, Originalism, supra note 113, at 993.

${ }^{244}$ CONG. GLOBE, 42d Cong., 2d Sess. 381 (1872). 
advantages, and conveniences created or regulated by law." The overriding privilege of United States citizenship, under this view, was equal treatment throughout public life.

One problem is that each of the areas addressed in the Bill had a distinct claim to being a privilege of citizenship. As to public inns and common carriers, supporters of the Bill emphasized the long common law tradition of the requirement of innkeepers to take all comers. ${ }^{245}$ The citations to the grand heritage of the common law are strikingly similar to the common law basis for the rights protected in the 1866 Act. In citing the Elizabethan Chronicles of Holingshed for the proposition that "every man may use his inn as his own house in England," Sumner was accessing a history of a right to use the inns in a sense similar to the right to contract. ${ }^{246}$ In this sense, the right of access to inns and conveyances was itself seen as a fundamental right. ${ }^{247}$ The innkeeper and common carriers owed a duty, it was claimed, to serve all equally; where there was a duty there was a corresponding right to obtain the service so long as the customer had the money and acted with propriety. Others supported this position. ${ }^{248}$ While

${ }^{245}$ E.g., id. at 383 (statement of Sen. Sumner).

${ }^{246} \mathrm{Id}$.

${ }^{247}$ One can connect this right of access for the traveler to the more general (and closely related) rights of mobility and commerce identified by Justice Washington in Corfield. If there is a right to travel on the highways and to conduct business throughout a state, there need also be a right to travel on public conveyances using those highways and to eat and board in the inns on those highways. In this respect consider the points made by Sumner's reading of letters from African-Americans supporting the Bill: H.M. Turner, an African-American state legislator in Georgia, describing how a female African-American school teacher had been unable to eat at the railroad eating houses for the entire trip from Washington, D.C. to Alabama, making her long trip to her place of employment enormously difficult. Id. at 430 . Similarly, W.H. Grey of Arkansas stated that "the colored people of Arkansas ... are subjected to untold inconveniences daily, thereby materially crippling their intercommercial intercourse ..." Id at 431 . In this respect, the right of access to common carriers and inns is a corollary to a meaningful right to travel and conduct business. Cf. CONG. GLOBE, 43d Cong., 1st Sess. app. 304 (1874) (statement of Sen. Alcom).

${ }^{248}$ E.g., CONG. GLOBE, 42d Cong., 2d Sess. $843-44$ (1872) (statement of Sen. Sherman):

What is a public inn? It is every man's home.... [T] he only laws that can be passed to exclude any one from a public inn are laws which involve order, decency, and quiet; not distinctions of race, color, or anything of that kind. .. . [T] he right to travel on your public highways, the right to travel 
the actual historical protection of a right to access may be less clear, ${ }^{249}$ certainly those who supported this access in the 1870 s viewed it as having a long established place in the common law and common law principles were, for some Republicans, a key source for defining the privileges of federal citizenship under the Fourteenth Amendment. ${ }^{250}$

As to theaters and other places of public amusement; Sumner did not have a parallel common law rule of equal treatment. He claimed, rather, that such places were "kindred to inns or public conveyances, though less noticed by jurisprudence" and it would be logically inconsistent to treat them differently. ${ }^{251}$ In a sense, he was placing certain activities into the same category as the inns; he was claiming a right for Congress to identify a fundamental activity. He also placed public, or common, schools in this category. Schools had no common law heritage of access, but because they existed through public taxation, were for the benefit of the community, and were to teach the principles of republican government, Sumner asserted that schools had a very strong claim to being in the category of public access facilities. ${ }^{252}$ Sumner's defense for his inclusion of churches and cemeteries was the thinnest, stating that insofar as they are "public in character and organized by law, they must follow the general requirement."253

Still, the question remained concerning how far Congress could legitimately go in regulating activities traditionally regulated by the states. This question of the extent of federal powers arose during the Enforcement Act debates and carried over to the debates on Sumner's Bill. Soon after Sumner's long defense of the Bill, Senator Frelinghuysen broached this topic. He argued that Congress did not have the authority under the Fourteenth Amendment to overtake the regulation of carriers, inns, etc., but that Congress did have the power to ensure that "every citizen shall be

on your public improvements, is a privilege that belongs to him as a citizen Id. not only of the State, but of the nation.

${ }^{249}$ See Joseph William Singer, No Right To Exclude: Public Accommodations and Private Property, 90 NW. U. L. REV. 1283, 1303-48 (1996).

${ }^{250}$ See supra note 248.

${ }^{251}$ CONG. GlOBE, 42d Cong., 2d Sess. 383 (1872).

${ }^{252}$ Id. at 383-84. Sumner argued that the purpose of schools is to prepare children for the duties of life in a democratic republic, and that children taught in an unequal (segregated) school system based on caste could, almost definitionally, not be taught republican principles. See also id. at 844 (statement of Sen. Sherman).

${ }^{253}$ Id. at 384. 
treated as a citizen" and that denial of access to rails and inns was a denial of the "equal rights of American citizenship."254 For Frelinghuysen, the key language of the Amendment was therefore the Citizenship Clause, and Section Five gave Congress authority to protect citizens qua American citizens, including their right to access inns and carriers.

Consider, for instance, the debate between Senators Thurman and Morton. Thurman, opposing the Bill, observed that the law sought to establish a privilege to access the listed facilities and institutions, and then adopted a version of the state action argument later used by the Supreme Court in finding the law unconstitutional. ${ }^{255}$ Senator Morton pointed out that this argument did not deny that the subject areas of the bill were privileges and immunities of national citizenship. Morton then asserted the power of the Congress to enforce national privileges and immunities:

If the right of a man to the equal enjoyment of the privileges of traveling belongs to him because he is a citizen of the United States, and that citizenship is created by the Constitution of the United States, then the protection of that privilege belongs to the Government of the United States. ${ }^{256}$

Morton further argued that the Fourteenth Amendment contemplates primarily congressional, rather than court, enforcement and that state "action" is not necessary for congressional action, although it might be for court action. Otherwise, the Amendment amounted to surplusage. Morton supported this position by observing the Amendment specifically authorized congressional enforcement, that a state law specifically denying rights would not require congressional action because the courts would have the power to overturn such laws, that therefore, for Section Five to have independent meaning, Congress must have the power to act absent state laws (or action). ${ }^{257}$ According to this theory, Congress possesses a power to address state failure, or inaction, in a way the courts might not. ${ }^{258}$

${ }^{254} \mathrm{Id}$. at 436.

${ }^{255}$ Id. at 496.

${ }^{256} \mathrm{Id}$. at $524-25$.

${ }^{257} I d$. at 525.

${ }^{258}$ Thurman responded by denying that Section Five added anything to the Constitution (it was only a restatement of congressional power generally) and that the whole weight of the rights protection of Fourteenth Amendment rested on a prohibition of state action. Id. at 526. Thurman also considered the Civil Rights Act of 1866 to be unconstitutional, at least in part. Id. at 527. Thurman's position represented the northern Democrat interpretation of the Fourteenth Amendment. 
Morton also argued, however, that the Amendment "does not create a new privilege or immunity" but simply asserts a national citizenship and right to pre-existing privileges and immunities. ${ }^{259}$ This was a common point in the debates, and runs somewhat counter to Sumner's implicit assumption that Congress could identify facilities not having a common law right of access and create such a right itself. The supporters of the Bill did not fully grapple with this problem, however, and it is hard to know how they resolved the issue. Perhaps they believed that the right of equal access existed broadly and was not based solely on common law principles, and so was not wholly created by Congress. Whatever the underlying reasoning of the Bill's supporters, it appears to have been necessary for many to have believed that they were not creating privileges but were rather implementing the broad concepts of the Amendment. ${ }^{260}$

The statements of Senator Carpenter are particularly revealing considering his shifting positions and relationship to the Slaughter-House cases. In 1873, Carpenter argued for a restrictive interpretation of the Fourteenth Amendment in his capacity as counsel to the Louisiana Slaughter-House company in Slaughter-House and opposed the eventually enacted (and weaker) bill after Slaughter-House. In 1872, and before the Slaughter-House arguments or decision, however, Carpenter supported a significant portion of Sumner's Bill. ${ }^{261} \mathrm{He}$ argued that the Reconstruction

Although the Democrats had opposed the battle over the Amendment, they eventually won the interpretive war before the Supreme Court. See also Balkin \& Levinson, supra note 128 , at 1098 . See generally BRANDWEN, supra note 219 , at 30-37, 62, 140-41.

${ }^{259}$ CONG. GLOBE, 42d Cong., 2d Sess. 525 (1872).

${ }^{260}$ This may reflect the rhetorical complexity of legislating on such broad principles. The political speaker often needs to engage the historical importance of the topic in order to assert successfully its implementation in the present. The political actor thus positions the changes as historically required (and the thing to be changed as inconsistent with history). Such "forensic" history is common for American politicians, judges, and lawyers. See John Phillip Reid, Law and History, 27 LOY. L.A. L. REV. 193, 204 (1993) (discussing judicial uses of history to support judicial activism). Contrary to Professor McConnell's belief, it is therefore not at all surprising that supporters of this 1875 Act did not assert their power to "create" privileges, but rather asserted that their position was consistent with common law history. See McConnell, Institutions and Interpretation, supra note 6, at 174.

${ }^{261}$ Carpenter disagreed with Sumner over the coverage of churches and jurors and the definition of public entity. CONG. GLOBE, 42d Cong., 2d Sess. 759-63, 820$21,825-27,843$ (1872). Tension is evident in this debate between Carpenter and Sumner over Carpenter's proposed amendment to Sumner's Bill. 
Amendments reconceived federalism because "[t]he sensitiveness that existed about interfering with States when the original Constitution was adopted had been drowned in blood."262 The Enforcement Clauses of the Reconstruction Amendment, therefore, did more than Senator Thurman claimed, because they permitted Congress to "enforce, by positive enactments, the principles intended to be secured by these amendments."263 This enforcement power under the Fourteenth Amendment, Carpenter argued, included the power to enforce national privileges and immunities, because the assertion of national citizenship and the mention of national privileges and immunities implied their existence. It is in this way that Section One accomplished far more than did the Privileges and Immunities Clause of Article IV. ${ }^{264}$

As to the subject of enforcement, Carpenter asserted a broad theory of national privileges that sounds remarkably like the arguments of his opposing counsel and the dissents in Slaughter-House (and, of course, remarkably like Carpenter's 1873 argument on behalf of Myra Bradwell's admission to practice law in Illinois):

The fourteenth amendment provides that no State shall make or enforce any law which shall abridge the privileges and immunities of any citizen. It has been asked in our recent debates what those words mean. The best definition I know is that given by the Supreme Court of the United States, in the case of Cummings v. The State of Missouri. The Court Say:

"The theory upon which our political institutions rest is, that all men have certain inalienable rights; that among these are life, liberty, and the pursuit of happiness; and that in the pursuit of happiness all avocations, all honors, all positions, are alike open to every one, and that in the protection of these rights all are equal before the law...."

... [I]t may safely be affirmed that the privilege of practicing law, if a man can meet the test and pass the necessary examination in the courts; the right of preaching the gospel, if employed and settled according to the usages of a particular church; the right of giving instruction in the public schools-all these are privileges of American citizens, and why can they not be taken away from him in a particular State? They might under the old Constitution, but not under the fourteenth amendment, because this

\footnotetext{
${ }^{262}$ Id. at 761 .

${ }^{263} \mathrm{Id}$.

${ }^{264}$ Id. at 762.
} 
amendment goes into every State and declares "You shall neither make hereafter, nor enforce if you have it at present, any law which shall abridge the privileges and immunities of a citizen of the United States."265

One would be hard pressed to find a broader definition of the Privileges or Immunities Clause in the congressional debates of either 1866 or the 1870s.

Notably, Carpenter also recognized the importance of balancing this broad interpretation of the Privileges or Immunities Clause with the continued importance of a sphere of state autonomy. ${ }^{266}$ This is consistent with the point made above in discussing the 1871 Enforcement Act, that Republicans were trying to define a new understanding of an overlapping federalism. Once again, the contours of this new federalism were still not clear, but Carpenter, as of February 1872, believed they included congressional power to enforce equal access to a wide range of privileges.

Supporters outside Congress likewise described the purpose of the Bill. Writing in 1872, Frederick Douglass argued:

the black man is not a free American citizen in the sense that a white man is a free American citizen; he cannot protect himself against encroachments upon the rights and privileges already allowed him in a court of justice without an impartial jury, [nor] can it be denied that the forcing of colored men to pay for what they do not get by railroad corporations or the refusal to allow the same accommodation to them as to other citizens $\ldots$ is an invidious discrimination amounting to an abridgement of citizenship rights. ${ }^{267}$

Douglass, as was his style, raised several critical arguments in this short excerpt. First, he asserted the white-rights-as-baseline theory of equality and freedom that was seen as one possible interpretation of the Civil Rights Act of 1866. Then, he observed that the already established rights and privileges of citizenship, such as the right to access the courts, established in the 1866 Act, were figmentary without subsidiary protections such as

${ }^{265}$ Id. (citations omitted).

${ }^{266} \mathrm{Id}$. at 763.

${ }^{267}$ Frederick Douglass, Give Us the Freedom Intended for Us, NEW NATIONAL ERA, Dec. 5, 1872 (quoted in McPherson, supra note 240, at 503). See also McPherson, supra note 240 , at 500 (quoting an abolitionist writing against public accommodation segregation and arguing that " $[\mathrm{i}] \mathrm{t}$ is necessary and proper that the law be appealed to, and that respectable, well-behaved persons of color are accorded the rights which belong to them as citizens"). 
jury service and composition. In this way, he established that the privileges that the Bill sought to enforce were valid for federal action because they were necessary for protection of the established privileges. Finally, he asserted that economic and social discrimination (requiring black purchasers of first-class tickets to ride on second-class railcars) itself abridged citizenship rights. Thus, Douglass set the Bill in the context of the establishment of national citizenship and the assertion of national privileges and immunities by the Fourteenth Amendment. ${ }^{268}$

As this discussion suggests, in the initial debates over the Civil Rights Bill, supporters understood the Fourteenth Amendment to enable Congress to enforce equality in a wide range of public activity because such activities were themselves privileges of national citizenship. ${ }^{269}$ The interpretive theory behind this argument, as evident in some of the supporters' statements, suggested that the privileges of national citizenship were not limited to the Bill of Rights but were found in the fundamental rights of the common law and the nature of government provisions, such as public schools. ${ }^{270}$ Moreover, Congress had the important power and responsibility to articulate the specifics of these privileges based on its own reading of the common law and government activities. The Privileges or Immunities Clause required an investigation into the fundamental rights of citizens, and Section Five placed Congress in charge of the inquiry. ${ }^{271}$

${ }^{268}$ See also CONG. GLOBE, 42d Cong., 2d Sess. 429 (1872) (letter of Resolutions (read by Sen. Sumner) from an assembly of four thousand black and white citizens of Georgia, asserting that "we can never be complete American citizens until such a law is enacted," and that daily degradations in public highways and institutions would be common "so long as we are denied the full rights of citizenship").

${ }^{269}$ For some other discussions of the Privileges or Immunities Clause in this context, both pro and con, see $i d$. at 843-45 (statement of Sen. Sherman); $i d$. at app. 25-26 (statement of Sen. Thurman); id. at app. 41-42 (statement of Sen. Vickers).

${ }^{270}$ See, e.g., Senator Sherman's grand statement:

What are those privileges and immunities? Are they only those defined in the Constitution, the rights secured by the amendments? Not at all. The great fountain head, the great reservoir of the rights of an American citizen is in the common law, the old charters that were wrenched by our ancestors five hundred years ago and two hundred years ago from English kings. Our rights are not limited to those given by the Constitution. What are those rights? Sir, they are as innumerable as the sands of the sea. You must go to the common law for them....

Id. at 843 .

${ }^{271}$ By saying that Congress was "in charge" of the inquiry, I mean that Congress (and not the Court) had the primary obligation to explore meanings and applications of meanings. I do not mean that Congress was the sole authority on the 
Importantly, the failure of the Bill at this point cautions against a simple conclusion that Republican interpretations of the Privileges or Immunities Clause had overwhelming support. But while the pre-SlaughterHouse Congress did not pass Sumner's Bill, the Bill received significant support in the Senate, especially among those who voted in favor of the Fourteenth Amendment. Of the twenty-two members of the Forty-second Congress who voted for the Fourteenth Amendment, twenty-one supported the Civil Rights Bill; only Senator Trumbull, who was backsliding to his Democratic roots, opposed it. ${ }^{272}$ Trumbull's defection is particularly telling since he was aligned by this point in time with a small but increasingly powerful group of moderate-conservative Republicans who formed or supported the rival Liberal Republican Party and, allying themselves with Democrats, opposed President Grant in the 1872 election. ${ }^{273}$ Indeed, the very fact that Trumbull opposed the Bill may support the consistency of the constitutional interpretation of the other Republican supporters. The moderate-conservative wing of the party had begun shifting away from positions on equality, rights, and federal powers that its own members asserted just half a decade earlier. ${ }^{274}$ That people such as Senator Trumbull were objecting to the Bill while simultaneously associating themselves with the people and party that opposed the Reconstruction Amendments and

meaning of the Privileges or Immunities Clause. In this regard, I am sympathetic to Professor McConnell's position that Congress has interpretative powers that entitle it to deference, but not "substantive" powers that render the Court's position irrelevant. See McConnell, Institutions and Interpretation, supra note 6, at 169-76. I am not convinced, however, that one can distinguish "interpretative" and "substantive" so easily with regard to the Privileges or Immunities Clause.

${ }^{272}$ See McConnell, Originalism, supra note 113, at 1054 (on Senate consideration of Sumner's rider); id. at 1062 (House consideration of parallel bill). VicePresident Colfax, who supported the Fourteenth Amendment as Speaker of the House in 1866, also voted in favor of Sumner's Rider. Id. at 1054.

${ }^{273}$ McPherson, supra note 240, at 502-03. The failure of the Bill in the Fortysecond Congress may well be attributable to Trumbull's opposition, since, as Chairman of the Senate Judiciary Committee, Trumbull was able to stymie Sumner's plans. See Kelly, supra note 240, at 546. One of the significant ironies of the period was Sumner's support for Trumbull's wing which formed its own party, the Liberal Republicans, to oppose President Grant in 1872. Sumner had opposed Grant's effort to annex the Dominican Republic, and Grant had helped force Sumner out of the chairmanship of the Senate Foreign Relations Committee. The breach between Sumner and Grant forced Sumner into the odd position of supporting main opponents of his beloved Civil Rights Bill. See FONER, supra note 114 , at 494-511.

${ }^{274}$ See sources cited supra note 219. 
legislation, may counsel more in favor of seeing the Bill as a logical extension of the "true" Reconstruction intent. At the very least it does not justify the counter-argument that these moderate-conservative Republican positions could themselves stand for the intent of the framers and supporters of the Reconstruction Amendments. ${ }^{275}$

The initial debates over the Civil Rights Bill thus reveal important aspects of the congressional interpretations of both the Privileges or Immunities Clause and congressional powers under Section Five. On the specific subjects of the Bill-public conveyances, public accommodations; public schools, etc. - there was significant support for the proposition that these were inherently privileges of citizenship and that equal access to them was therefore required. Moreover, Congress saw itself as possessing the power to determine the content of the Clause, and it did so by exploring the fundamental rights of citizenship through the common law and other sources. Indeed, some in Congress argued for a very broad view of the possible content of the Privileges or Immunities Clause which would, combined with congressional powers of interpretation, enable Congress to define a broad range of federal rights of citizenship. ${ }^{276}$ Thus, as the Court prepared to decide the Slaughter-House Cases, there had already been a significant exploration of the meaning of the Privileges or Immunities Clause within Congress. A significant portion of the Congress (including Senator Carpenter, who would argue in favor of a restricted view of the Fourteenth Amendment in his role as counsel to the Slaughter-House corporation) contended that the Clause meant more than mere incorporation

${ }^{275} C$. McConnell, Originalism, supra note 113, at 1105-07 (discussing possible views of the changes in opinions from 1866-1875).

${ }^{276}$ Senator Sherman was perhaps the most forceful advocate for this position. $\mathrm{He}$ argued that the privileges of federal citizenship were innumerable and were based on common law rights and the Declaration of Independence, and that the potential breadth of the rights was supported by the invocation of rights retained by the people in the Ninth Amendment. CONG. GLOBE, 42d Cong., 2d Sess. app. at 26 (1872). Here, Sherman was also responding to the conservative position of Senator Thurman that the Clause did no more than incorporate the first eight amendments. Id. at 25-26. Thurman argued that the rights retained by the people were not citizenship rights, but rights as against the federal government. Id. at 26 . Citizenship rights are certainly not limited to those that do not restrain the government (else the rights of first eight amendments would not be citizenship rights either). On this dispute between Thurman and Sherman, see Maltz, The Concept of Incorporation, supra note 55, at 526-27. On the fact that incorporation was a conservative position during this period, see generally Wildenthal, The Lost Compromise, supra note 4. See also Maltz, The Concept of Incorporation, supra note 55 , at 527-30. 
of the Bill of Rights, that the common law was a significant source for citizenship privileges, and that the Amendment enabled Congress to particularize the meaning of the Clause. Furthermore, some in Congress had advanced a potentially broader understanding of the Clause, in which both the Declaration of Independence (Senator Sherman's point) and evolving principles of government activities (Senator Sumner's implicit point regarding public schooling) were sources for determining privileges of citizenship. The range of interpretation was quite wide indeed.

\section{E. The Civil Rights Act of 1875 Post-Slaughter-House}

Regardless of how much weight one might accord the arguments of supporters of the Bill from 1870-1873, it remains significant that the Bill was understood within the context of the Privileges or Immunities Clause at the same time that the Supreme Court was considering the SlaughterHouse Cases. The Slaughter-House revisionists, in concentrating on the incorporation of the Bill of Rights, overlook the more actively debated contemporaneous issue of congressional powers to enforce the Privileges or Immunities Clause. A Court writing in 1873 could not have been ignorant of how its own interpretation of the Clause, even in a case not raising question of congressional powers, would affect such debates within and without Congress; nor could the advocates arguing the case have been ignorant, in particular Senator Carpenter, who argued for the SlaughterHouse corporation on the side supported by the Court's decision.

Congress did take notice. ${ }^{27 ?}$ The Court decided Slaughter-House on April 14, $1873 .{ }^{278}$ When the Civil Rights Bill was reintroduced to the House in the Forty-third Congress in December of that year, Congressman Beck opposed the Bill with new ammunition: Justice Miller's opinion for the Court. He argued that the Court decided that "these rights pertaining to the rights of corporations, and inferentially to common schools, are not embraced in the powers confided to Congress by the constitutional amendments. Under the authority to enforce the amendments by appropriate legislation, these are not rights about which Congress has authority to legislate."279 He quoted at length from Miller's opinion on the definition of the Privileges or Immunities Clause, and concluded that:

${ }^{277}$ For other analyses of the congressional response to Slaughter-House, see Aynes, Constricting the Law of Freedom, supra note 24, at 679-81; McConnell, Originalism, supra note 113, at 998-1005.

${ }^{278}$ The Slaughter-House Cases, 83 U.S. (16 Wall.) 36, 57 (1872).

${ }^{279}$ CONG. REC., 43d Cong., 1st Sess. 342 (1873). 
[T] he whole spirit and bearing of the decision is against the constitutionality of the law now proposed, matters of regulation as to education, local corporations, and their rights and privileges being subjects which bear only on the individual as a citizen of the. State, and not as a citizen of the United States. ${ }^{280}$

Even though Slaughter-House itself did not involve questions of congressional powers, its restrictive interpretation of the Privileges or Immunities Clause had an immediate impact on congressional debates because, as Representative Beck argued, if corporate regulation remained an exclusive question of state citizenship privileges, one logical implication was that regulation of other traditional state functions-schools, inns, and common carriers-did as well. Other opponents cited Slaughter-House to the same effect. ${ }^{281}$

Supporters responded to this constitutional attack in a number of ways. Some dealt with the decision directly. Senator Frelinghuysen provided an extensive post-Slaughter-House defense of the Bill and argued that the Court's limitation of the Privileges or Immunities Clause was irrelevant because the Court held that "freedom from discrimination" remained a right of national citizenship. Frelinghuysen argued that the privileges to access to inns, schools, railroads, etc., were not at issue in the Bill, but only the equality of access for all citizens. ${ }^{282}$. Frelinghuysen sought a way to harmonize the Court's limitation of the Privileges or Immunities Clause with the equality goal of the Civil Rights Bill. His position, though partially consistent with some of the pre-Slaughter-House arguments in Congress, still represented a more conservative movement because it avoided any implication that the rights of access at issue were themselves fundamental on a national scale. ${ }^{283}$ Even among the more forceful defenders of the Bill,

${ }^{280} \mathrm{Id}$.

${ }^{281}$ Id. at 453 (statement of Rep. Atkins); id. at 4086-87 (statement of Sen. Thurman); CONG. REC., 43d Cong., 1st Sess. app. 2-3 (1873) (statement of Rep. Southard); CONG. GLOBE, 43d Cong., 2d Sess. 948-49 (1875) (statement of Rep. Finck).

${ }^{282}$ CONG. REC., 43d Cong., 1st Sess. 3453-54 (1874).

${ }^{283}$ For example, compare Frelinghuysen's post-Slaughter-House position to his earlier statement about the Fourteenth Amendment: "The [F]ourteenth [A]mendment goes much further than establishing 'equality' between blacks and whites [which the Civil Rights Act of $1866 \mathrm{did}$ ]. It asserts United States citizenship and defines some of its privileges and immunities." CONG. GLOBE, 42d Cong., 1st Sess. 499-500 (1871). In his 1874 speech, Frelinghuysen was clearly uncomfortable with his equality-as-privilege-and-immunity position, for later in the speech 
therefore, Slaughter-House effected a rhetorical shift away from a fundamental or natural rights position and toward a mere equality approach to the Privileges or Immunities Clause. ${ }^{284}$

Frelinghuysen's invocation of equality as a privilege of United States citizenship also reflected another tact taken by Republican supporters of the Bill in order to address Slaughter-House: a movement away from the Privileges or Immunities Clause and toward the Equal Protection Clause. ${ }^{285}$ This argument was articulated by Representative Elliott who, after discussing Slaughter-House, stated:

[I]t is under this clause of the [F]ourteenth amendment that we place the present bill, no State shall 'deny to any person within its jurisdiction the equal protection of the laws.' No matter, therefore, whether his rights are held under the United States or under his particular State, he is equally protected by this amendment.

The distinction between the two kinds of citizenship is clear, and the Supreme Court has clearly pointed out this distinction, but if it has nowhere written a word or line which denies to Congress the power to prevent a denial of equality of rights, whether those rights exist by virtue of citizenship of the United States or of a State. ${ }^{286}$

This move allowed the supporters of the Bill to call on other positions in Miller's opinion to contrast the Bill with the issue in Slaughter-House. Elliott argued, for instance, that the only basis for denying equal protection was the legitimate use of the police power: regulation of slaughter-houses clearly was within the police power and discrimination on the basis of race was not. Moreover, the Court expressly linked the Reconstruction Amendments generally, and the Equal Protection Clause specifically, to racial injustice and had alluded to congressional powers to legislate against

he regressed to his earlier argument by quoting approvingly Justice Bradley's lower court opinion in Slaughter-House: " "[The Fourteenth Amerdment] not merely requires equality of privileges, but it demands that the privileges and immunities of all citizens shall be absolutely unabridged, unimpaired." CONG. REC., 43d Cong., 1st Sess. 3454 (quoting Live Stock Assoc. v. Crescent City Live Stock Co., 15 F. Cas. 649 (C.C. La. 1870)).

${ }^{284}$ See supra notes $92-119$ and accompanying text.

${ }^{285}$ See McConnell, Originalism, supra note 113, at 1001.

${ }^{286}$ CONG. REC., 43d Cong., 1st Sess. 408-09 (1874). 
discrimination. ${ }^{287}$ By this interpretation of the case, African-Americans could benefit from the Equal Protection Clause in ways that the New Orleans butchers could not. The Bill's supporters were attempting to turn Miller's restrictions of the Amendment into affirmative support for congressional actions within what they defined as the remaining scope of the Amendment. ${ }^{288}$

Moreover, as Professor McConnell has pointed out, Section One of the Bill itself was revised to reflect the shift away from the Privileges or Immunities Clause and toward the Equal Protection Clause: "Whereas the Sumner Bill had begun with the words 'no citizen of the United States shall,' the [revised] bill applied to 'all persons within the jurisdiction of the United States.' ${ }^{\prime 289}$ This point is not quite as strong as McConnell asserts, however, because the revised Bill (and eventual Act) reflects the uncertainty within Congress regarding the ongoing shift in constitutional rhetoric. Section Two of the Act, which enforced the general principles of Section One, retained the citizenship language. ${ }^{290}$ Whether this difference in language was intended to have legal impact is unclear, but it does reveal the confusion engendered by the Court's Slaughter-House decision.

Despite the frequent discussions of Slaughter-House within the halls of Congress, many supporters seem to have ignored the Court's potentially devastating interpretation of the Privileges or Immunities Clause, and remained convinced that the Privileges or Immunities Clause enabled legislation of traditionally state areas and that fundamental rights were still protected by the Privileges or Immunities Clause. Representative Butler, for example, upon the reintroduction of the Bill after Slaughter-House (but before a full congressional discussion of the case) argued that all state legislation "that seeks to deprive a well-behaved citizen of the United States of any privilege or immunity to be enjoyed, and which he is entitled to enjoy in common with other citizens, is against constitutional enactment." ${ }^{291}$ Similarly, when Senator Thurman spoke at length against the Bill, weaving in his interpretation of Slaughter-House, supporters of the Bill

${ }^{287}$ See, e.g., id. at 3454 (statement of Sen. Frelinghuysen) (1874) (quoting Slaughter-House). See also CONG. REC., 43d Cong., 1st Sess. app. 358-59 (statement of Sen. Morton) (quoting Slaughter-House).

${ }^{288}$ See also id. at 360-61 (statement of Sen. Morton).

${ }^{289}$ McConnell, Originalism, supra note 113, at 1070.

${ }^{290}$ Civil Rights Act, 18 Stat. 335 (1875).

${ }^{291}$ CONG. REC., 43d Cong., 1st Sess. 340 (1873). Cf. CONG. REC., 43d Cong., 1st Sess. app. 304-06 (statement of Sen. Alcorn) (connecting access to inns and common carriers to the right to travel). 
rejected his reading. Thurman argued that the Court had cited Corfield in order to distinguish between fundamental rights such as those mentioned in Corfield (interpreting Article IV), which were privileges of State citizenship only, and those other rights which were national privileges. The debate continued:

[Mr. THURMAN.] ... Now the question comes, what are those privileges and immunities that appertain to men as citizens of the State? If they appertain to them as citizens of the State, they are not those peculiar privileges that appertain to them as citizens of the United States, but they are privileges and immunities that belong to them in virtue of their State citizenship. The first definition was by Justice Washington in the case of Corfield v. Coryell.

[Mr. MORTON.] I wish to call the attention of the Senator to the fact that the privileges and immunities of citizens of the State, spoken of in the article of the Constitution he has just read [Article IV], are treated as being identical with the privileges of citizens of the United States under the [F]ourteenth [A]rticle, and the judge [Justice Miller] reads from the case of Coryell to show that those rights were identical in their character. [Mr. THURMAN.] There is nothing in the world to show that under the [F]ourteenth [A]mendment they are treated as identical at all, but on the contrary this very case decides that they are not identical. ...

[Mr. MORTON.] The Senator does not understand me. The court draws a distinction between the privileges of citizens of the United States and of citizens of a State, but the privileges meant by the original article referred to are those which are now treated as the privileges of a citizen of the United States.

[Mr. THURMAN.] Yes, in this Hall, but in no court.

[Mr. MORTON.] In that decision.

[Mr. THURMAN.] No, sir; not a bit of it. ${ }^{292}$

Morton balked at Thurman's more accurate reading of Miller's opinion; Morton's position that the Fourteenth Amendment constitutionalized into national citizenship the fundamental rights of Corfield is the argument of the dissenters in Slaughter-House, not the majority. Indeed, when Thurman then asserted that Slaughter-House plainly rendered the Bill unconstitutional and that it was "the decision of the highest judicial tribunal of this country, clothed, as we all admit, with the final determination of what is the law and Constitution of this land" Senator Edmunds interjected, "I do not

${ }^{292}$ CONG. ReC., 43d Cong., 1st Sess. 4087 (1873). 
admit it." ${ }^{293}$ Edmunds simply refused to admit that the Court's interpretation of the Privileges or Immunities Clause was either correct or the law of the land. And Senator Morton, while adopting an equal protection argument, ${ }^{294}$ also asserted that a citizen of the United States had a right, as a U.S. citizen, to attend a public theater. ${ }^{295}$

The Republican supporters of the Bill not only asserted an alternative interpretation of Slaughter-House, they also (as Senator Edmunds' interjection suggests) asserted their own authority to interpret the Constitution. Thus Senator Morton argued that:

[I]f it be conceded now ... that colored children cannot be denied the benefit of common schools without a violation of the fourteenth amendment, and that Congress has the power to enforce that amendment by such legislation as in the judgment of Congress and not of the courts is suitable and proper for that purpose, then the argument is at an end ... ${ }^{296}$

Morton here argued, both explicitly and implicitly, for an interpretive role for Congress. Explicitly, he suggested that once the topic came within the scope of the Fourteenth Amendment, Congress had the exclusive interpretive power to determine how to enforce the Amendment through legislation. He also implicitly assumed for Congress a significant, though not necessarily exclusive, power to decide that the Amendment guaranteed access to public education. While the opponents of the Bill had a reasonable argument that Slaughter-House (rightly or wrongly) did not allow for a congressional role in determining the privileges and immunities of national citizenship, the Court had not addressed the former issue of congressional power to fashion enforcement legislation as it saw fit. Thus, the Republican tactic transformed into an effort to assert equality as a privilege (and alternately focus on equal protection) and also to assert congressional power to create enforcement legislation. ${ }^{297}$

Another similar, but distinct, approach to the Privileges or Immunities Clause after Slaughter-House was taken by Senator Boutwell. He viewed the Court's apparent division of privileges and immunities into two separate camps-State and Federa -as a "great mistake," and instead

${ }^{293}$ Id. at 4088.

${ }^{294}$ CONG. REC., 43d Cong., 1st Sess. app. 358-59 (1873).

${ }^{295}$ Id. at 360 (debate between Sens. Morton and Merrimon).

${ }^{296} \mathrm{Id}$. at 359. Hale).

${ }^{297}$ See, e.g., CONG. GLOBE, $43 \mathrm{~d}$ Cong., $2 \mathrm{~d}$ Sess. 980 (1875) (statement of Sen. 
argued for equality as "the first right"'of United States citizenship. He then connected the two spheres of citizenship by claiming that the federal privilege of equality meant that States, in granting state-based privileges, had to do so equally. ${ }^{298}$ This intermingling of federal privilege with state privileges enabled Boutwell and other supporters to further justify the Bill within the rhetoric employed by the Court in Slaughter-House. ${ }^{299}$

This position did, however, render uncertain Republican claims that various substantive grants were themselves fundamental privileges. Whereas prior to Slaughter-House some Republican supporters of the Bill argued for joint federal and state jurisdiction over fundamental, Corfieldian privileges, Slaughter-House made them coy. Thus, Boutwell and Morton both danced around the question of whether states could simply withdraw the state-based privileges altogether. Morton refused to answer this precise question from Senator Merrimon, and instead simply asserted that theaters were places of public amusement and therefore had to be open to all. ${ }^{300}$ Similarly, Boutwell spoke of education as fundamental to democracy and as a basic privilege, albeit one granted by the state.$^{301}$ Senator Howe argued that the Bill "proposed that a citizen shall have a right to travel along the public thoroughfares if he pays his fare, and shall have a right to send his children to the public school if he meets the charges, although he is not white. ${ }^{" 302}$ In each instance, the speaker assumed that the privilege at issue did exist and would continue to do so. But whereas before Slaughter-House there seemed to be two rhetorical positions for Republicans favoring the Civil Rights Bill-one of equality and another of fundamental national privileges-Slaughter-House forced supporters of the Bill to emphasize equality and to limit these stronger claims, which urged subjects such as education and access to common carriers to be deemed fundamental national privileges.

Because Republicans were able to rely on the equality justification for the Civil Rights Bill, the rhetorical shift away from substantive privileges had only a small impact, if any, on the success of the Bill within Congress. ${ }^{303}$ Once the Bill was stripped of its more politically sensitive

${ }^{298}$ Id. at 4116.

${ }^{299}$ Compare Boutwell's position to Professor Curtis' similar interpretation of the Privileges or Immunities Clause. See generally Curtis, Resurrecting the Privileges, supra note 68; Curtis, Historical Linguistics, supra note 144.

${ }^{300}$ CONG. REC., 43d Cong., 1st Sess. app. 360-61 (1873).

${ }^{301}$ CoNG. REC., $43 \mathrm{~d}$ Cong. 1st Sess. 4116 (1873).

${ }^{302} \mathrm{Id}$. at 4147.

${ }^{303}$ One important exception was Senator Carpenter, who switched from support to opposition once Slaughter-House was decided. His opposition appears to have been based on his belief that courts would overturn the Act after Slaughter-House. 
provisions, especially equal access to education (a compromise made possible in part by Charles Sumner's death), and once a lame-duck Republican Congress could act with lessened concern for political consequences, the Bill was finally passed and signed in 1875.

Nonetheless, Slaughter-House effected the subtle elimination of fundamental privileges of national citizenship from the congressional and national political discourse over the Fourteenth Amendment and Reconstruction. Congress no longer sought to explore the entitlements of national citizens under the Privileges or Immunities Clause, or to explore its own duties to enforce and protect those privileges. This is not to say that the rhetorical shift determined this denouement for congressional action under the Privileges or Immunities clause. Certainly the political effects of the elections of 1874 and 1876 had a devastating effect on both the power and the positions of the "radical" Republican Party of Reconstruction. ${ }^{304}$ Yet we cannot fully perceive the impact and meaning of Slaughter-House without attention to its effect not just on Supreme Court doctrine, but on the constitutional discourse and actions of Congress as well. As we can see, Slaughter-House may well have helped cripple the nascent congressional efforts at creative legislation designed to implement the Privileges or Immunities Clause. We should not undertake a revisionist reading of Slaughter-House (or for that matter a revival of the Privileges or Immunities Clause) without attention to whether the Court's holding and interpretation of the Privileges or Immunities Clause, quite aside from the incorporation of the Bill of Rights, comport with either the text or its complex and multifaceted history.

\section{THE CIVIL RIGHTS CASES: \\ DENOUEMENT FOR CONGRESSIONAL POWERS}

While the decision in The Slaughter-House Cases may have altered the rhetoric behind the Civil Rights Act of 1875, it did not itself compel any particular answer to the Act's constitutionality. Slaughter-House had not addressed congressional enforcement powers, and the privileges claimed by the plaintiffs and rejected by the Court did not include those protected by the Civil Rights Act. The case did suggest, however, that only a very limited collection of privileges were truly federal under the Privileges or Immunities Clause and thus "enforceable" by Congress, as the opponents of the Act were eager to point out. It would have been quite plausible for

See McConnell, Originalism, supra note 113, at 1004-05.

${ }^{304}$ FONER, supra note 114 , at 549-50, 564-87. 
the Court, in considering the constitutionality of the Civil Rights Act of 1875 , to have rested upon Miller's interpretation, and to have declared the Act as encompassing subjects beyond the powers of the federal government.

The Court did not do so. In the Civil Rights Cases, the Court instead focused on the state action requirement of the Fourteenth Amendment and found that the Act, by addressing conduct engaged in by private parties, went beyond the scope of the Amendment. ${ }^{305}$ This move can be explained in a number of ways. First, the state action rationale addressed both possible justifications for the Act under Section One: the Privileges or Immunities and Equal Protection clauses. As was explained, SlaughterHouse caused a shift in the rhetoric of constitutional justification for the Act, and the Equal Protection Clause could arguably do the work of its cousin, the Privileges or Immunities. Clause. Both clauses are introduced and modified by the "No State shall" language of Section One. ${ }^{306}$ By defining state action so as not to include the possible connections between the state and the facilities covered by the Act, the Court was able to clip the wings of both clauses with a single doctrinal edge.

Second, Justice Bradley wrote the opinion. Although he lost the battle for an expansive judicial reading of the Privileges or Immunities Clause in Slaughter-House, it is not likely that he would readily employ the reasoning of Slaughter-House, which he disliked, if other reasons existed. Moreover, it may not have been Bradley's distaste for Miller's argument that caused Bradley to rely on the state action rationale; Bradley may well have been implementing his own version of the bounds of the new federalism that was different from Miller's. Recall that the question for reconstructed federalism was "how far?" Bradley may have viewed federal powers as expansive enough to allow the federal courts to overturn state legislation restricting individual rights but not expansive enough to allow congressional legisla-

${ }^{305}$ The Civil Rights Cases, 109 U.S. 3, 10-19 (1883). The Court also rejected an argument based on the Thirteenth Amendment. Id. at 20-25. While I address this briefly below, the Thirteenth Amendment was not the primary basis for congressional action cited by Congress itself; the argument also does not directly implicate the Privileges or Immunities Clause as I am discussing it in this Article. There are, however, important potential connections between conceptions of citizenship under the Privileges or Immunities Clause and conceptions of liberty and labor under the Thirteenth Amendment.

${ }^{306}$ The Privileges or Immunities Clause is introduced by "No State shall." The Due Process Clause comes in the second part of the sentence and is introduced by "nor shall any state." The Equal Protection Clause comes in the third portion of the sentence, introduced by "nor deny." 
tion over private conduct not directly affected by state action. Such a view would be consistent with a Lochnerian perspective, maximizing individual freedoms from government restraint, because it would allow for the greatest opportunity to strike down state legislation restricting individuals while simultaneously prohibiting federal legislation restricting individuals. To this extent, perhaps the Civil Rights. Cases and the Slaughter-House dissents are indeed compatible.

There is some doubt, however, as to the depth of Bradley's convictions on these points and as to the motivations for his decision. Not only had Bradley dissented in Slaughter-House, he had also written opinions prior to 1876 vigorously defending federal powers over civil rights issues. In Blyew, Bradley dissented from the Court's judgment that, although the right of black witnesses to testify in court was protected by the Civil Rights Act of 1866 , it was unenforceable in that case because the witnesses were not parties to the murder case (a prosecution of a white man for killing several African Americans). Bradley rejected the formalistic reasoning of the Court and relied instead on the underlying purpose of the Act. In ringing language Bradley declared:

I have no doubt of the power of Congress to pass the law now under consideration. Slavery, when it existed, extended its influence in every direction, depressing and disfranchising the slave and his race in every possible way. Hence, in order to give full effect to the National will in abolishing slavery, it was necessary in some way to counteract these various disabilities and the effects flowing from them. Merely striking off the fetters of the slave, without removing the incidents and consequences of slavery, would hardly have been a boon to the colored race. Hence, also, the amendment abolishing slavery was supplemented by a clause giving Congress power to enforce it by appropriate legislation. No law was necessary to abolish slavery; the amendment did that. The power to enforce the amendment by appropriate legislation must be a power to do away with the incidents and consequences of slavery, and to instate the freedmen in the full enjoyment of that civil liberty and equality which the abolition of slavery meant. ${ }^{307}$

Bradley reiterated this position in the circuit opinion in SlaughterHouse, arguing in favor of congressional powers to define and implement the privileges of citizenship and reaffirming the legitimacy of the Civil Rights Act of 1866, even though that Act was not itself implicated in the

${ }^{307}$ Blyew v. United States, 80 U.S. (13 Wall.) 581, 601 (1872). 
case.$^{308}$ Bradley continued this reasoning in his circuit opinion in United States v. Cruikshank, written shortly after the Supreme Court's decision in Slaughter-House, where he wrote, "I am inclined to the opinion that congress has the power to secure that right not only against the unfriendly operation of state laws, but against outrage, violence, and combinations on the part of individuals, irrespective of state laws. ${ }^{309}$ One commentator has argued that, at the time of writing the Cruikshank opinion, Bradley viewed race as the factor that converted criminal violence subject to exclusively state law into violations of federal law. ${ }^{310}$ Thus the riotous violence against blacks at issue in Cruikshank transformed the acts from those subject to state law alone to those subject to federal regulation and prosecution.

It is hard to view this line of Bradley's reasoning as in any way consistent with his opinion in the Civil Rights Cases. The Civil Rights Act of 1875 plainly addressed problems of racial discrimination. If racial discrimination arising out of slavery could convert the subjects of state law into the subjects of federal law in Cruikshank, why could they not also in the Civil Rights Cases? ${ }^{311}$ Similarly, if the Enforcement Clause of the Thirteenth Amendment logically imbued Congress with broader powers

${ }^{308}$ State ex rel. Belden v. Fagan, 22 La. Ann. 545, 1870 WL 92 (La. Nov. 1870) (No. 2508).

${ }^{309}$ United States v. Cruikshank, 25 F. Cas. 707, 713 (C.C.D. La. 1874). See also John Anthony Scott, Justice Bradley's Evolving Concept of the Fourteenth Amendment from the Slaughterhouse Cases to the Civil Rights Cases, 25 RUTGERS L. REV. 553, 558-59 (1971). The Supreme Court's opinion in Cruikshank is also important for understanding the Court's use of congressional power under Section Five. See United States v. Cruikshank, 92 U.S. 542 (1875). On Cruikshank, see Maltz, The Concept of Incorporation, supra note 55, at 529-33; Newsom, supra note 3, at 712-20; Wildenthal, The Lost Compromise, supra note 4, at 1147-60. Maltz identifies Cruikshank and not the Civil Rights Cases as the origin of the shift away from congressional power under the Amendment. See Maltz, The Concept of Incorporation, supra note 55, at 533.

${ }^{310}$ See Scott, supra note 309, at 559 (citing Justice Bradley's diary from this period).

. ${ }^{311}$ One could perhaps draw the distinction between racial violence and racial segregation and argue that Bradley believed racial violence constituted a violation of federal rights in a way that segregation might not. Bradley did not adopt the distinction explicitly. Such a distinction may not explain his support for the 1866 Civil Rights Act in his Blyew dissent and his Slaughter-House circuit opinion. However, it is notable that while the civil right to testify was the main issue in Blyew, protection of the right was, on the facts of the case and in many other similar cases, necessary to punish whites who committed violent acts against blacks. 
than formalistic implementation of the letter of the substantive clause, then the same Enforcement Clause in the Fourteenth Amendment logically could allow Congress to interpret more broadly the state action limitation of the first clause of the Amendment.

One possible answer to this inconsistency is to admit the inconsistency and seek a non-doctrinal explanation. The best candidate here would be Bradley's efforts to implement the Compromise of 1877. Bradley was the pivotal member of the Electoral Commission appointed by Congress to resolve the disputed electors from three states in order to determine whether Hayes or Tilden would be President. He was appointed to a commission otherwise evenly divided between seven Republicans and seven Democrats. He then cast the deciding votes awarding all the disputed electors to Hayes, the Republican. As part of the agreement between the parties to have Hayes become President, Republicans had agreed to end federal supervision of race relations in the South. ${ }^{312}$ Thus Bradley, it has been suggested, found it essential to limit the reach of the federal government in order to implement the agreement made possible by his votes. ${ }^{313}$

This rather Machiavellian view of Bradley's own little "switch in time" 314 is not without its critics. Michael Collins recently countered that Bradley's judicial opinions are consistent. Collins contends that Bradley consistently advocated protection against private interference of rights that were established by the Constitution, particularly those in the Reconstruction Amendments, and protection only against governmental interference of rights that originated in the common law. ${ }^{315}$ Collins identifies this as a distinction between newly-conferred rights and pre-existing rights, with the strict state action requirement imposed by Bradley in the Civil Rights Cases applying only to the latter. Collins offers a sensitive reading of Bradley's lower court opinion in Cruikshank, where the Justice indicated that congressional powers to enforce rights might well depend on the right

${ }^{312}$ See Scott, supra note 309, at 567-69.

${ }^{313}$ See id. at 569. See Michael W. McConnell, The Forgotten Constitutional Moment, 11 CONST. CoMMENT. 115, 138 (1994) [hereinafter McConnell, The Forgotten Constitutional Moment]. Cf. CURTIS, No STATE SHALL ABRIDGE, supra note 24, at 179 (arguing that Bradley indeed changed positions, but dating the change at 1874 , prior to the 1876 election crisis).

${ }^{314}$ See also McConnell, The Forgotten Constitutional Moment, supra note 313, at 138 (comparing the Republican shift in the 1870 s to the infamous switch in time of the New Deal).

${ }^{315}$ See Michael G. Collins, Justice Bradley's Civil Rights Odyssey Revisited, 70 TUL. L. REV. 1979, 1987-2000 (1996). 
being protected ${ }^{316}$ According to this view, the privileges of citizenship protected by the Privileges or Immunities Clause of the Fourteenth Amendment could plausibly be considered pre-existing in the sense that states were expected to protect those privileges prior to the Amendment, and that all the Amendment did was allow the federal government to step in where the state failed to protect the privileges:

Collins' view stumbles on the Thirteenth Amendment, however. Even if Bradley could be interpreted as invoking a consistent interpretation of the Fourteenth, he refused, in the Civil Rights Cases, to agree that, as Justice Harlan argued in dissent, segregation in public accommodations was a badge of servitude that Congress had the power to prevent under the Thirteenth Amendment. Bradley had argued just this in Blyew, where he recognized congressional power to legislate for the elimination of the "incidents and consequences" of slavery ${ }^{317}$ Similarly, as Collins perceptively highlights, in Cruikshank, Bradley suggested that Congress had the power to punish white individuals for preventing black citizens from leasing and cultivating a farm because "it would be a case of interference with that person's exercise of his equal rights as a citizen because of his race." ${ }^{\prime 318}$ For Bradley to draw the line of congressional powers under the Thirteenth Amendment at leasing and cultivating land, but not accessing public accommodations while travelling to the location where one would lease the land, seems less related to the distinction between "newlyestablished" and "pre-existing" rights than Collins would have us believe. 319

A better explanation for Bradley's decisions is that Bradley, like many of his contemporaries, did not believe that "social" rights were protected by the Reconstruction Amendments. Historians have argued that in the midnineteenth century there was a widely-held tripartite distinction among political, civil, and social rights. Civil rights included rights to contract, to hold and lease property, and to access the courts (all covered under the 1866 Civil Rights Act); political rights included the right to vote (the

${ }^{316}$ United States v. Cruikshank, 25 F. Cas. 707, 708 (C.C.D. La. 1874) (“One method of enforcement may be applicable to one fundamental right, and not applicable to another.").

${ }^{317}$ See Blyew v. United States, 80 U.S. (13 Wall.) 581, 601 (1872).

${ }^{318}$ Cruikshank, 25 F. Cas. at 712; Collins, supra note 315, at 1991.

${ }^{319}$ Collins recognizes that the Thirteenth Amendment analysis presents the main obstacle to his interpretation. Collins argues that the identification of race as the key factor was what made the Thirteenth Amendment "newly-established." See Collins, supra note 315, at 1998. The problem is that the Amendment, like Section One of the Fourteenth, is not, by its language race-based. 
Fifteenth Amendment); and access to public accommodations (at issue in the $1875 \mathrm{Act}$ ) were arguably a species of social rights. Bradley, it could be argued, viewed only the former two as protected by federal constitutional law. ${ }^{320}$ This would explain his support for the 1866 Act and not for the 1875 Act. It is also consistent with Bradley's language in the Civil Rights Cases. Bradley went to great pains to argue that although the Thirteenth Amendment established "universal civil and political freedom" and "clothe[d] congress with power to pass all laws necessary and proper for abolishing all badges and incidents of slavery in the United States," it did not encompass public accommodations. ${ }^{321}$ This was because Bradley refused to admit that segregation from public accommodations was a badge or incident of slavery, despite its origin in the Black Codes of the era of slavery. He then explicitly distinguished "those fundamental rights which are the essence of civil freedom" and "appertain to the essence of citizenship," which he claimed were protected by the 1866 Act and the Thirteenth Amendment, from the "social rights of men and races in the community," which were the subject of the 1875 Act and outside the ambit of the Thirteenth Amendment. ${ }^{322}$

The social rights distinction, however, does not explain why Bradley chose the state action doctrine in the Civil Rights Cases. If he thought that social rights were not protected, they would be unprotected by the Privileges or Immunities and Equal Protection Clauses as well as the Thirteenth Amendment. He could have adopted a version of Miller's view and held the subjects at issue in the Act as inherently not part of the Federal Privileges or Immunities. Instead, he expressly refused to decide whether the right to public accommodations was "one of the essential rights of the citizen" under the Fourteenth Amendment, perhaps indicating a lack of agreement within the majority of the Court on the issue. ${ }^{323}$ Bradley further suggested that the Fourteenth Amendment has the broader substantive scope-it may cover the denial of "the right to pursue any peaceful avocations allowed to others"324 — but narrower congressional empowerment, while the Thirteenth Amendment has a narrower scopo-limited to abolition and the relief of civil and political disabilities based on race as had already been enacted-_but a broader empowerment for Congress. ${ }^{325}$

${ }^{320}$ See id. at 1999 n.106; HYMAN \& WIECEK, supra note 97, at 394-402.

${ }^{321}$ The Civil Rights Cases, 109 U.S. 3, 20-22 (1883).

${ }^{322} \mathrm{Id}$. at 22.

323 Id. at 19.

${ }^{324} \mathrm{Id}$. at 23. Here Bradley seems to attempt to reinsert ideas from his SlaughterHouse dissent and also to forget his Bradwell concurrence.

${ }^{325}$ Id. 
Ultimately it may have been a complex combination of patent and latent rationales-including the civil-political-social rights division, the "newly-established" versus "pre-existing" distinction, a particular concern with racial violence, and a growing frustration with and disregard for Reconstruction-that motivated Bradley's various judicial opinions through 1883. ${ }^{326}$ Whatever the reasons, his Civil Rights Cases opinion thoroughly stunted the development of the Privileges or Immunities Clause and congressional interpretive enforcement precisely because he greatly restricted congressional enforcement powers under Section Five. Even if there had been room to maneuver within the substantive straight jacket of Slaughter-House, the Civil Rights Cases effectively ended the prospect for subsequent judicial reception of congressional action in the area. ${ }^{327}$

The sole remaining voice on the Court in favor of broader interpretations of the Reconstruction Amendments and congressional powers under them belonged to Justice Harlan. In one of his earliest significant dissents, ${ }^{328}$ Harlan advanced many of the same arguments for the Act's constitutionality under the Fourteenth Amendment as were put forward by the Republican congressional supporters of the Civil Rights Act a decade earlier. For instance, Harlan, like Senator Sumner and others, argued that there was a long common law history behind open access to public accommodations, particularly at inns and in transportation. ${ }^{329} \mathrm{He}$ also argued that licensing of public establishments provided the necessary connection to governmental action to satisfy any state action requirements

${ }^{326}$ Cf. Aynes, On Misreading John Bingham, supra note 93, at 102 (Bradley's change mirrored the national mood) (citing Ruth Whiteside, Justice Joseph Bradley and the Reconstruction Amendments (1981) (unpublished Ph.D. thesis, Rice University) (on file with author)).

${ }^{327}$ Of course, after the Election of 1876 , Congress was not likely to develop an interpretation of the Privileges or Immunities Clause on civil rights issues. This does not mean, however, that if the Court had accepted congressional actions in the Civil Rights Cases that later Congresses might not have been more willing to explore legislation under the Clause.

${ }^{328}$ Harlan dissented in several cases prior to the Civil Rights Cases. See, e.g., Ruggles v. Illinois, 108 U.S. 526 (1883) (on the issue of judicial review of railroad rate regulation). None of the cases were as significant, nor were the dissents as strongly worded. It was his dissents in the Civil Rights Cases and Hurtado v. California, 110 U.S. 516 (1884), that first gave him notoriety as a Justice. See LOREN P. BETH, JOHN MARSHALL HARLAN: THE LAST WHIG JUSTICE 151 (1992). See also LINDA PRZYBYSZEWSKI, THE REPUBLIC ACCORDING TO JOHN MARSHALL HARLAN 90-96 (1999).

${ }^{329}$ Civil Rights Cases, 109 U.S. at 37-47. 
of the Fourteenth Amendment. ${ }^{330}$ Each of these arguments reveals that if a distinction among civil, political, and social rights was in fact commonly accepted, it was by no means clear that access to public accommodations was wholly a social right; the categorization of public accommodation access was the contested ground in the late Reconstruction period. ${ }^{331}$ Harlan argued that the right to access the public highways was no more a social right than the right to use the public market, post office, or court room. ${ }^{332}$

Bradley's jettison of public accommodation access into the nether region of social rights was not so obviously correct, particularly for Republicans familiar with the debates of the 1860s and 1870s. Indeed, given the strong Republican support for the privilege of public accommodations in the early 1870s, what is surprising is not that Harlan dissented in the Civil Rights Cases, but that no other Republican Justice sided with him (although the retired Justice Swayne, a Slaughter-House dissenter, did send Harlan a letter complimenting Harlan on the Civil Rights Cases dissent). ${ }^{333}$ Bradley's shift away from a rhetoric supporting civil rights to a rhetoric surprisingly hostile to $\mathrm{it}^{334}$ reflects (whether or not it was directly the result of) a deeper transition in the Republican Party and the nation generally away from civil rights and federal legislative protection of the rights of blacks, a transition forged in the congressional debates over the legislation implementing the Reconstruction Amendments in the early 1870s, and the

${ }^{330} I d$. at 41 .

${ }^{331}$ Harlan apparently accepted the legitimacy of the civil/political/social categories; for example, he seems to have been ambivalent about whether public schooling was more properly categorized as a civil or social right and was thus ambivalent about integrated public education. See PRZYBYSZEWSKI, supra note 328 , at $99-101$.

${ }^{332}$ Civil Rights Cases, 109 U.S. at 59-60. Linda Przybyszewski argues convincingly that Harlan was protesting against what in effect was civil slavery similar to what free blacks, North and South, had endured prior to the Civil War. She also argues that Bradley and others simply could not grasp the significance of this idea. PRZYBYSZEWSKI, supra note 328, at 92-94. Bradley's dissent in Blyew, however, makes it seem at least possible for him to have understood the meaning of "civil slavery." Blyew v. United States, 80 U.S. (13 Wall.) 581, 585 (1871).

${ }^{333}$ See Aynes, Constricting the Law of Freedom, supra note 24, at 676 n.359.

${ }^{334}$ Bradley's Civil Rights Cases opinion is notable in large part for his aggressive rejection of a constitutional obligation to support civil rights for African-Americans: "[For blacks who have] emerged from slavery ... there must be some stage in the progress of his elevation when he takes the rank of a mere citizen, and ceases to be the special favorite of the laws." Civil Rights Cases, 109 U.S. at 61 . See supra note 307 and accompanying text to compare the tone and substance of his Civil Rights Cases opinion to his dissent in Bylewv. United States. 
formation of the Liberal Republican Party in $1872 .{ }^{335}$ The political and social shift away from the energies that enabled some early congressional interpretive legislation under the Privileges or Immunities Clause is not a reason, however, to allow the Court's doctrinal enforcement of the shift to blind us to the possibilities for future constitutional interpretations.

\section{CONCLUSION}

CONSTITUTIONAL MEANINGS AND HISTORICAL THREADS: CONGRESS AS INTERPRETER OF THE PRIVILEGES OR IMMUNITIES CLAUSE

The recent re-readings of The Slaughter-House Cases by Kevin Newsom and Professor Wildenthal focus on the wrong misreading. While it may be true that scholars and courts have misread Justice Miller's opinion for the Court in Slaughter-House to have prevented the incorporation of the Bill of Rights to the states, the more important problem with Miller's opinion is not its position on incorporation, but its misreading of the Fourteenth Amendment's Privileges or Immunities Clause. Miller wrongly relegated the fundamental privileges of citizenship, which were extensively discussed by the drafters of the Amendment and subsequent Congresses, to state privileges and immunities. In doing so, the Court greatly inhibited the ongoing congressional debates over specific definitions of the Clause in the context of congressional enforcement powers under Section Five of the Amendment. Slaughter-House thus became a two-pronged attack on the Amendment, preventing both judicial definition of federal privileges and congressional definition through enforcement. When combined with the still vigorous perspective of The Civil Rights Cases, ${ }^{336}$ which diminishes the interpretive role of Congress under Section Five, such revisionism, despite its apparent expansion of the Clause, produces a remarkably thin clause indeed.

The Slaughter-House revisionists are too quick to adopt Miller's treatment of the Privileges or Immunities Clause. They unnecessarily fear Miller's monster of an untamed federal government swallowing up all safeguards of federalism and states' rights. In doing so they fail to account for the development of an alternate interpretive path-congressional development and protection of the privileges of citizenship-which might, if given enough time, implement more fully the fundamental privileges desired by many framers of the Amendment and retain concurrent state powers over those privileges as well. By considering congressional actions

${ }^{335}$ See supra notes 272-75 and accompanying text.

${ }^{336}$ See, e.g., City of Boerne v. Flores, 521 U.S. 507 (1997). 
and debates between the time of the drafting of the Amendment and the decision in Slaughter-House, we learn what the revisionists overlook: the Reconstruction Congresses, which included many who voted for the Amendment, were well aware that congressional enforcement of the Amendment included an interpretive power and that many in these Congresses understood that their legislation on civil rights was based on their own implementation of fundamental privileges of citizenship through the Privileges or Immunities Clause.

Such historical investigations raise critical issues for any contemporary revival of the Privilege or Immunities Clause. First, Slaughter-House should not continue to be guiding authority, even with an incorporationist spin, because the Court simply ignored significant evidence supporting a broader understanding of the Clause. Second, the historical record about the "intended" content of the Clause contains sufficient ambiguity that we must confront the possibility that natural or fundamental rights beyond the Bill of Rights could be encompassed by the Clause; this choice is not one dictated by oracles of original intent or Court precedent, but rather must be made openly by modern interpreters through a dialogue with the past. Third, modern interpreters can engage with the interpreters of the past to help test and refine current views, and such a process should include an investigation of congressional interpretations from the Reconstruction period. Finally, there are significant indications in the historical background of the Amendment that Congress was to play an important interpretive role in developing the law surrounding the Clause. Indeed, the role Congress played during Reconstruction suggests a theory of interpretive enforcement whereby Congress, in enforcing the broad concept of privileges and immunities, also interprets the Clause by particularizing it. Given the historical basis for this view and the textual support in Section Five of the Amendment, such congressional power should not be rebuffed too lightly. Congress may indeed be the most appropriate body, historically and institutionally, to implement the specifics of citizenship privileges and immunities, and such may prove a more fruitful path for future legal and scholarly development than a restructuring of the foundation of the incorporation of the Bill of Rights. 
